National Library

oi Canada

Acquisitions and

Bibliographic Services Branch

395 Wellingtun Streel

Uttawa, Ontario

K1A ON4
Bibliothèque nationale

तu Canada

Direction des acquisitions et

des services bibliographiques

395. rue Wellinglen

Ottawa (Ontano)

KIAONA
The quality of this microform is heavily dependent upon the quality of the original thesis submitted for microfilming. Every effort has been made to ensure the highest quality of reproduction possible.

If pages are missing, contact the university which granted the degree.

Some pages may have indistinct print especially if the original pages were typed with a poor typewriter ribbon or if the university sent us an inferior photocopy.

Reproduction in full or in part of this microform is governed by the Canadian Copyright Act, R.S.C. 1970, c. C-30, and subsequent amendments.
La qualité de cette microforme dépend grandement de la qualité de la thèse soumise au microfilmage. Nous avons tout fait pour assurer une qualité supérieure de reproduction.

S'il manque des pages, veuillez communiquer aver, l'université qui a conféré le grade.

La qualité d'impression de certaines pages peut laisser à désirer, surtout si les pages originales ont été dactylographiées à l'aide d'un ruban usé ou si l'université nous a fait parvenir une photocopie de qualité inférieure.

La reproduction, même partielle, de cette microforme est scumise à la Loi canadienne sur le droit d'auteur, SRC 1970, c. C-30, et ses amendements subséquents. 
Gothic Bodies:

The Politics of Pain in Romantic Fiction

\author{
by \\ Steven Bruhm \\ Department of English \\ McGill University
}

August, 1992

A Thesis submitted to the Faculty of Graduate studies and Research in partial fulfillment of the requirements of the degree of Doctor of Philosophy.

(C) Steven Bruhm, 1992 
The author has granted an irrevocable non-exclusive licence allowing the National Library of Canada to reproduce, loan, distribute or sell copies of his/her thesis by any means and in any form or format, making this thesis available to interested persons.
L'auteur a accordé une licence irrévocable et non exclusive permettant à la Bibliothèque nationale du Canada de reproduire, prêter, distribuer ou vendre des copies de sa thèse de quelque manière et sous quelque forme que ce soit pour mettre des exemplaires de cette thèse à la disposition des personnes intéressées.

L'auteur conserve la propriété du droit d'auteur qui protège sa thèse. Ni la thèse ni des extraits substantiels de celle-ci ne doivent être imprimés ou autrement reproduits sans son autorisation. 


\begin{abstract}
In the ideology of sentimentalism, physical sensation integrates the parts of the body into a whole, and the fragmented members of the body politic into a social community. However, intense pain is always an individual experience. It not only isolates us from other people, but it also isolates us from our own bodies: pain renders our bodies out of control. Moreover, pain attacks our very notion of self by threatening to render us unconscious, and unable to perceive that self. This complex of problems became especially acute for late eighteenth-century writers, as they tried to reconcile their sympathy for the French Revolution with the intense pain that the Revolution signified. What they articulated was a process by which the self initially identifies with the pained body of the other, but then appropriates that pain to make it one's own, thereby isolating the self from infectious Revolutionary sympathies.
\end{abstract}


Dans l'idéologie de la sensibilité, la sensation physique intègre les parties du corps dans un ensemble, et les membres fragmentés du corps politique dans une communauté sociale. Cependant, la douleur intense est toujours une expérience individuelle. Non seulement elle nous isole des autres, mais en plus, elle nous isole de nos propres corps: la douleur rends nos corps hors conirôle. D'ailleurs, la douleur attaque notre idée même du soi, en meraçant de nous rendre inconscients, et incapables de nous apercevoir, Cet assemblage de problèmes devenait spécialement aigu pour les écrivains de la fin du dixhuitieme siècle, quand ils essayaient a réconcilier leur sympathie pour la révolution française avec la douleur intense que la révolution signifiait. Ils articulaient un procédé dans lequel ie soi s'identifie initialement avec le corps douleureux de l'autre, pour ensuite approprier cette douleur et en faire la sienne. De cette manière, le soi s'isole des sympathjes révolutionnaires contagieuses. 
Acknowledgements

Preparation of this dissertation was assisted by a Doctoral

Fellowship from the Social sciences and Humanities Research

Council of Canada, and by a Research Assistantship from McGill University.

I would like to thank the editors of Eighteenth-Century Life for their permission to reprint an article entitled, "William Godwin's Fleetwood: The Epistemology of the Tortured Body," which compriscs a substantial part of chapter four of this work. I would also like to thank the participants in my aerobics classes at Maison Alcan, and at the Montreal and Halifax YMCAs for allowing me to practice torture techniques on them during the writing of chapter four. 
Table of Contents

Delacroix, The Death of Sardanapalus............. v

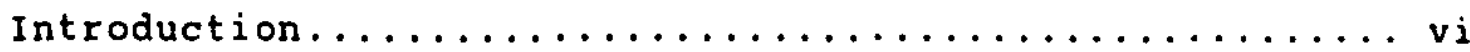

Chapter One: The Politics of Pain................

Chapter Two: Imagining Pain................. 56

Chapter Three: Spectacular Pain: Politics and the

Romantic Theatre.................117

Chapter Four: The Epistemology of the Tortured Body.... 178

Chapter Five: Aesthetics and Anesthetics at the

Revolution................... 227

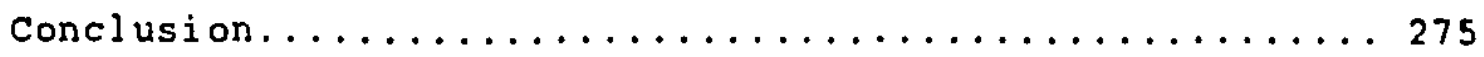

Bibliography......................... 283 


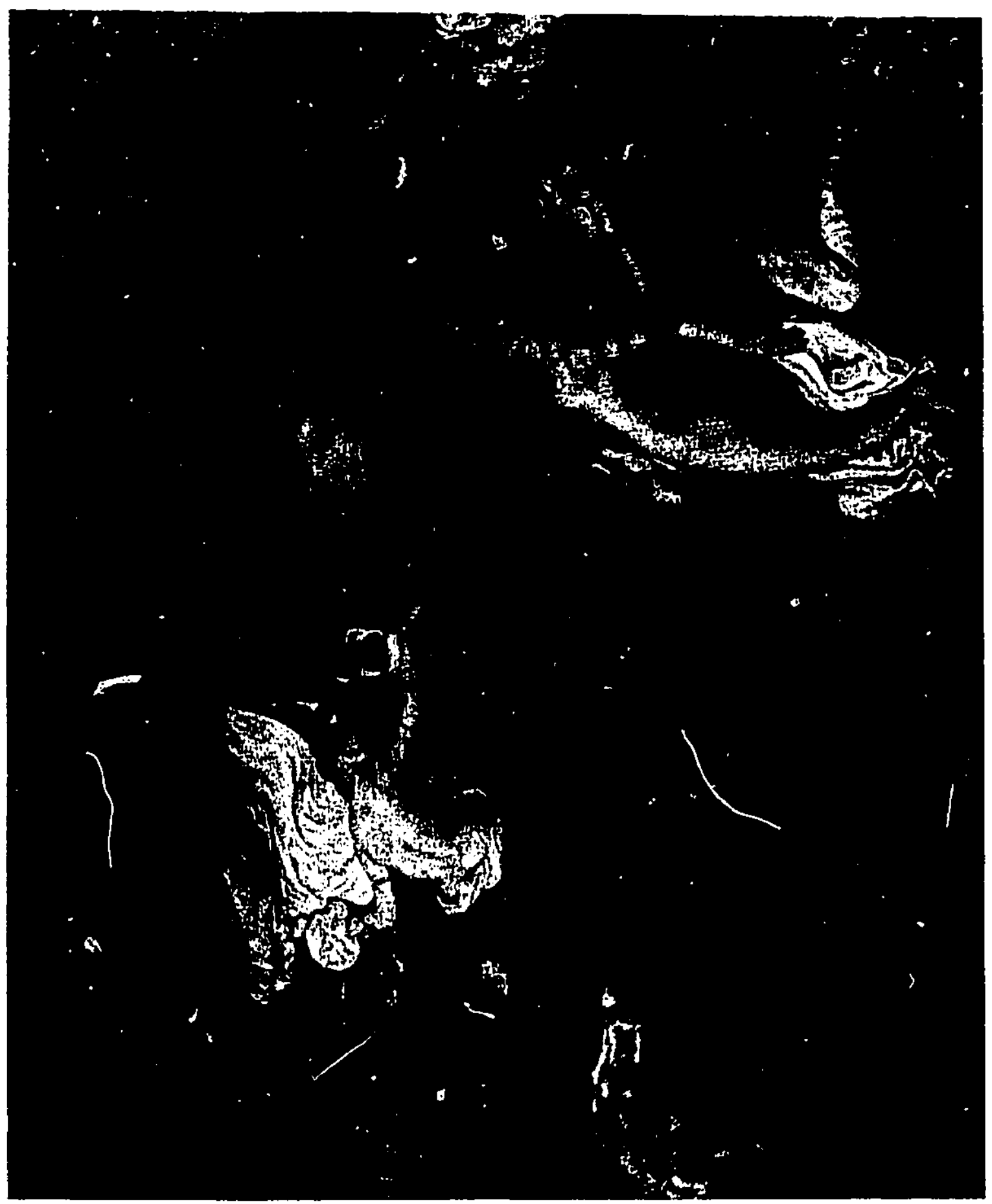


Introduction

Eugene Delacroix's 1827 canvas, The Death of Sardanapalus (see previous page) is not about the death of Sardanapalus. The moment captured by the painting immediately precedes the one in which the Assyrian king of Byron's drama will drink poison and immolate himself on his own bed. What Delacroix has chosen to present is a king who watches others die, a king who, in the painting, remains untouched. Poised with seeming insouciance on his bed, surrounded by rjches and lushly attired, sardanapalus watches the assassination of his concubines by the soldiers of his treasonous satraps. The painting is not about the death of Sardanapalus so much as it is about Sardanapalus's contemplation of death. It indulges what Norman Bryson has called "the beauty of barbarism"1 to contrast the thinking about pain with the experience of pain itself. It sets the life of sardanapalus's mind squarely against the lives of the harem's bodies.

This division of mind and body is replayed through anothet division, a veritable separation in the canvas. As Jack $\mathrm{J}$. spector notes, the painting is troublesome for the split between the background and the foreground, between the "opposed moods of pensive melancholy and animal energy, and of the detachment of the mental from the physical."2 The concubines' life-sized bodies eclipse the king who looks on from a dark background [that] seems rather more like a somber stage setting than a believable receding space, 
especially in view of lts apparent division from the brightly ill uminated foreground, across which figures move like actors downstage, under the spotlight.

(p. 18 )

The light, entering from the top left of the canvas, illuminates and magnifies the women and their murderers, drawing our attention away from the king and into the foreground. Our eye sweeps in an arc from side to side, following the light from left to right, and with it, we survey the act of carnage commitied before us. And this same light creates a shadow in which lits the figure of the king. That shadow envelops Sardanapalus as it. would a spectator beyond a brightly it stage.

The division of body and mind, moreover, is emphasized by the very bodies which are the subject of Sardanapalus's gaze. The women's bodies, like the bodies of their murderers, are mostly naked and exposed. Their glowing skin is set of by deep velvets of red and green, and by the lush pearls on earlobe, arm, and ankle. This sensuous nakedness, against which the sadistic violence is committed, depicts Delacroix's fascination with the violent in the erotic--that familiar freudian paradigm of sex and death--a fascination that has resulted in critical dis-ease with the painting since its appearance in 1828.3 Sensuous exposure here becomes synonymous with vulnerability, and the body, once the site of Sardanapalus's pleasure, is, in the painting, a proclamation of human fragility. The body's susceptibility to pleasure bespeaks the body's susceptibility to pain. Moreover, 
this fragility is avoided in the depiction of the king. His body is fully covered--except for the forearm, face, and toes; his gown is not dishevelled, let alone bloodstained. The servant bearing the cup of poison that will kill him is recessed, almost invisible, the deadly urn just one more glittering bauble in the palace's splendor. At the moment in the canvas, sardanapalus is both surrounded by carnage and immune to it; he is an interested, and yet a disinterested, spectator.

Norman Bryson finds in the painting those two moments which, for Delacroix, must be "taken together to define the work of culture: a primitive state from which culture emerges, and a later or higher state where it risks the return of that which has been repressed" (p. 205). The Death of Sardanapalus is about that moment when it becomes evident that a holocaust is necessary to destroy an existing culture if only in order to save it. Bryson argues that for Delacroix, as for Freud, culture is a novt: away from primal urges, but only to have those urges return as various forms of discontentment. In the story that Delacroix gets from Byron, Sardanapalus has refused slavish submission to what could be called primal urges by declaring himself unwilling to wage war, to assert power unduly, and to inflict pain. His peaceable kingdom is ordered by adherence only to pleasure. However, this order is destroyed by a return to war, violence, and carnage-in short, by a return of the repressed. But with the return of that repressed comes another kind of order, and another kind of repression. While Sardanapalus has outlawed 
certain primal urges, he has indulged others: he has been eating, drinking, and loving in typical Byronic fashion, and his passions are threatening the country with destruction. By eschewing repression of the body, by indulging food, sex, and freedom from pain, Sardanapalus has evoked the greatest repression of that body that is possible: the murder of his subjects, and his own eventual suicide. In this painting, as in Byron's play, the repression of physicality is essential to the social order.

Repression is, of course, essential to a theory of the Gotric, that poor cousin and contemporary to Romanticism. In one of the most important early essays to influence criticism of the Gothic--Freud's "The Uncanny," written in 1919--Freud discusses the Gothic as a study in the uncanny, a study in the return of various repressed experiences. The uncanny, says Freud, is in reality nothing new or alien, but something which is familiar and old--established in the mind and which has become alienated from it only through a process of repression. . [ [,] something which ought to have remained hidden but has come to light.1

One of these repressions, a very important one for Freud, has to do with the body. Freud recalls the story of Hoffmann's SandMan, that mythical agent of terror "who tears out children's eyes" (p. 227). Then he reminds us: "Many adults retain their apprehensiveness in this respect, and no physical injury is so much dreaded by them as an injury to the eye" (p. 231). This fear of bodily violation, Freud argues, displaces another, more 
primal, yet equally physical dread: the dread of castration. The castration complex, he argues, is symptomatic--indeed, a foundation--of our fear of injury, death, and the dead body that constitutes our experience of the uncanny. In one sense, then, it is a repression of the body--the eye, the penis, physical power in general--that returns in our daily experience to be defined as the uncanny.

From this opening premise, Freud goes on to enumerate a number of instances in which the uncanny is a return of repressed anxieties about the body:

Dismembered limbs, a severed head, a hand cut of $\mathrm{f}$ at. the wrist, feet which dance by themselves...- all of these have something peculiarly uncanny about them . . To some people the idea of being buried alive by mistake is the most uncanny thing of all. (p. 244) As an experience rooted in the body, and marked by a return of the body's repressed fragility and vulnerability, Freud's uncanry can in some ways be said to define Sardanapalus's experience. He has repressed the possibility of physical violence; he has sublimated his kingly responsibility to act aggressively into a love of eroticism; he has privileged a life of pleasure over a life of pain. In the moment captured by Delacroix's painting, that repressed violence returns, and the body--afflicted, severed, cut--proclaims its primacy, its irrepressibility, its material existence. 
The depiction of the Assyrian king as distanced contemplator of carnage and violence aligns him to some degree with the Romantic tradition of which Delacroix was both apostle and critic. Sardanapalus is not only the haughty, Byronic bourgeois standing outside the sphere of human action, but also the subject-spectator who tries to make sense of what is happening before him. He is an exotic avatar of Wordsworth or Coleridge, Blake or shelley, all of whom, in their different ways, constructed an intellectual, imaginative theory to transcend the carnage near them, in France. Like Sardanapalus, they sought to process the French Revolution, the Napoleonic wars, and England's Tory response through the point of view of a distanced and transcendent spectator. The split between sardanapalus and his harem, then, is in a general way the split between Romanticism and the Gothic, between the life of the mind and the immediacy of the body. As Robert Hume argued in 1969, the key difference between Romanticism and Gothicism is that while the former offers escape through transcendence (theoretically, at least), the latter is bound by fixity and limitation.s In Delacroix's painting--and, I believe, in the Gothic novel as well--that essential limitation is the body, a body whose pain and vulnerability repeatedly signal its return from the repressions of the transcendent Romantic consciousness.

The body, and the body in pain, are the subject of this study. The Death of Sardanapalus is a painting replete with painful bodies, bodies I am calling "Gothic": viewed by a poised, 
distanced spectator, the Gothic body is that which is put on excessive display, and whose violent, vulnerable immediacy gives both the Delacroix painting and Gothic fiction their beautiful barbarity, their troublesome power. Studying pain, however, puts me somewhat in the position of sardanapalus. He contemplates pain, and has the luxury of doing so because he is not yet feeling it. And in that schism between thinking about pain and feeling it, the painting has fostered a moral debate:

Sardanapalus has been condemned for remainina outside a catastrophe that he has to a great degree created.6 But such condemnation does not allow the validity of the activity Sardanapalus is performing in the canvas, the activity of thinking about pain. It does not allow that thinking about fain may itself be a legitimate and necessary enterprise. We are reluctant to think about pain. When describing this ploject, for example, I have often been met by responses like, "Don't you think that's rather sick?" (the "sick," it seems, beirog molally suspect); or, "Wouldn't you rather think about Romantic pleasure?" (as if that had never been done). These reactions, and the dearth of Romantic criticism dealing with physical pain, are telling. Pain is the great repressed in criticism of the Romantics, just as, for Freud, the body was the great repressed in the constitution of social order. The Gothic invites the repressed to return; it brings us on stage with pain. With all the paradoxes inherent in the attempt, this phenomenon is worth thinking about. 
Notes

1.Norman Bryson, Tradition and Desire from David to Delacroix (New York: Cambridge University Press, 1987), p. 186.

2.Jack. J. Spector, Delacroix: The Death of Sardanapalus (New York: Viking Press, 1974), p. 23.

3. Ibid., p. 18 .

4. Sigmund Freud, The standard Edition of the Complete Psychological Worls of Sigmund Freud Vol. 17, trans. James Strachey (London: Hogarth Press, 1955), p. 241.

5.Robert D. Hume, "Gothic vs. Romantic: A Revaluation of the Gothic Novel," PMLA 84 (1969), p. 289. 6. Spector, p. 65 . 
It is by [sympathy] that we enter into the concerns of others, that we are moved as they are moved, and are never suffered to be indifferent spectators of almost anything that men can do or suffer. For sympathy must be a source of substitution, by which we are put into the place of another man, and affected in many ways as he is affected. . . . Edmund Burke, Enquiry into ..... the Sublime and Beautiful.

Hmmmmm . . my body hurts just thinking about it.

Madonna, "Hanky Panky" 
Chapter One: The Politics of Pain

I

Pain and danger, sickness and death--these ideas, according to Edmund Burke's 1757 A Philosophical Enquiry into the origin of our Ideas on the sublime and Beautiful, give rise to the strongest passions of which we are capable, and can be a source of pleasure leading to the sublime.l Even stronger than pleasure itself, pain, when rightly experienced and contemplated, can produce an "elevation of the mind" which "ought to be the principle end of all our studies" (p. 52). Burke's proclamation on the aesthetic pleasures of pain was part of a larger fascination with physical pain at the end of the eighteenth century, a fascination tnat, according to Mario Praz, underlies much of its literary production. 2 Burke is paid tribute, unwittingly, by that other great master of pain, the Marguis de Sade, whose thesis in his 1795 Philosophy in the Bedroom is similar in some ways to Burke's:

there is no doubt that we are much more keenly affected by pain than by pleasure: the reverberations that result in us when the sensation of pain is produced in others will essentially be of a more vigorous character, more incisive, will more energetically resound in us, will put the animal spirits into circulation and these, directing themselves toward the nether regions by the retrograde motion essential to 
them, instantly will ignite the srgans of voluptuousness and dispose them to pleasure. ${ }^{3}$

The geographic location of pain in sade differs from that in Burke: whereas pain stimulates Sade's "nether regions," it appeals in Burke to the mind, a mind capable of intense excitation. But the effects of pain are similar: both theorists are moved toward the most intense experience they can imagine--an experience which both excites and exhausts.

The fascination which Burke and Sade articulate--although on very different moral planes-is part of a widespread concern for writers at the end of the eighteenth century. The concern as Burke and sade define it is, among other things, an aesthetic one, dealing with the way we respond to the physical distress of others, and the categories we construct to interpret those responses. But the later eighteenth and early nineteenth century was preoccupied not only with the observed pain in another person, but also with experienced pain in the self. For Lord Byron, the "great object of life is sensation--to feel that we exist--even though in pain.. . "4 Percy shelley's career as a lyrical poet depended to a great extent upon falling upon the thorns of life and bleeding. Keats sees "mortal pains," the "worldly elements" that prey upon sensation, as necessary to the soul's formulation. In his famous letter of 21 April 1819 to George and Georgiana Keats, the "World of pains" is an essential teacher of consciousness; pain is necessary to the Romantic construction of the identity.s And for coleridge, poetic 
production often arises as a direct result of pain. He writes in the Biographia Literaria,

I am well aware that in advanced stages of literature when there exist many and excellent models, a high degree of talent, combined with taste and judgement and employed in works of imagination, will acquire for a man the name of a great genius; though even that analogon of genius which in certain states of society may even render his writings more popular than the absolute reality could have done would be sought for in vain in the mind and temper of the author himself. Yet even in instances of this kind, a close examination will often detect that the irritability which has been attributed to the author's genius as its cause did really originate in an ill conformation of the body, obtuse pain or constitutional defect of pleasureable sensation. What is charged to the author belongs to the man, who would probably have been still more impatient but for the humanizing influences of the very pursuit which yet bears the blame of his irritability.6

Literary distinctiveness--what we see as irritability in a writer like Pope, Byron, or even Coleridge himself--often proceeds from physical pain. Pain in the self actually helps to formulate a sensibility. In Coleridge's view, it is often a part of the 
construction of the self that, at the same time, is being tyrannically abused by that pain.

Like Sade's voluptuous instructors, Byron and Keats, Shelley and even Burke attempt to create pleasure out of physical pain, and to collapse the distance we usually place between the two experiences. In the eighteenth century, that distance was part of a legacy firmly established by John Locke. In An Essay Concerning Human Understanding, Locke reifies and moralizes the distinction between pleasure and pain:

Things then are Good or Evil, only in reference to Pleasure or Pain. That we call Good, which is apt to cause or increase Pleasure, or diminish Pain in us: or else to procure, or preserve us the possession of any other Good, or absence of Evil. And on the contrary we name that Evil, which is apt to produce or increase any Pain, or diminish any pleasure in usi or else to procure us any Evil, or deprive us of any Good. 7

Here Locke establishes the tradition that Burke will pick up, which argues that "the removal or lessening of a Pain is considered, and operates as a pleasure: And the loss or diminishing of a Pleasure, as a Pain" (II,20,xVi). Physiological and moral life operate in proportion: an increase of pleasure designates an increase of the good, and an increase of pain designates an increase of evil. But this somewhat mechanical equation of pleasure/pain with good/evil assumes that one gets no pleasure in someone else's pain, an assumption that later 
eighteenth-century thinkers did not wholeheartedly accept. Man as he was described by Hobbes exists in a state of selfishness. Such a selfish creature may glean something more precious from the observation of pain than the mere ability to designate it as evil. For Joseph Addison, imagined suffering can "teach us to set a just value upon our own condition, and make us prize our good Fortune which exempts us from the like Calamities."g The pleasure we feel in literature--a pleasure we cannot feel, says Addison, in "actual" observations of suffering--arises as we compare ourselves to the literary victim: "we consider the Misfortunes we read in History or Poetry, either as past, or as fictitious, so that the Reflection upon our selves rises in us insensibly, and over-bears the Sorrow we conceive for tine Sufferings of the Afflicted." Like Walter Benjamin's "storyteller," the Addisonian reader is drawn to novelistic suffering "in the hope of warming his shivering life with a death he reads about."lo From Addison's pioneering distinction, we find the eighteenth century moving away from a distinction between pleasure and pain, toward the beginnings of a pleasure in pain.

That pleasure in pain is located not only in the observation of someone else's intense physical feeling, but also in the experience of one's own. The exquisite distresses which are a benchmark of late eighteenth-century prose are connected to a movement to define the concept of "aesthetics" at the end of the eighteenth century. As Terry Eagleton explains, the term 
"aesthetic" was first used by the German theorist Alexander Baumgarten in his Aesthetica of 1750. Baumgarten's formulation of the aesthetic, says Eagleton, designated "the whole region of human perception and sensation, in contrast to the more rarifiec. domain of conceptual thought."1 "Aesthetic" suggested the materiality of sense perception as it grew out of Lockean empiricism and sense awareness, and it emphasized the importanc.. of the perceiving body in the material world as the privileged source of knowledge. In original aesthetics, "things" were privileged over "thoughts"; physical sensations were more closely attended to than were abstract ideas. This privileging of bodily reactions manifests itself in Burke's Enguiryy, as in so many other works. In the Enguiry we are given a long dissertation on the physiology of pain, fear, sublimity, and beauty. The anatomical descriptions that Burke provides relate to what John Beer describes as a change wrought by eighteenth-century medical discoveries and their relation to ontological aesthetics. Beer says that, in the eighteenth century, experiments on the human heart changed the way the educated person saw its functions: no longer a simple metaphor for social sympathy and community, the. heart came to be seen as a thermometer of one's emotional state. in that the heart beats faster and more perceptibly when one is excited.12 Thus, for Beer, "the actual movements of physical heart and physical bloodstream can be intimately involved" in oul relationship with other animate beings (p. 16). This physiology, part of a growing interest in Natural Philosophy, marks the 
development which Eagleton describes as "the first stirrings of a primitive materialism--of the body's long inarticulate rebellion against the tyranny of the theoretical." Hence, the assertion that begins The Ideology of the Aesthetic: "Aesthetics is born as a discourse of the body" (p. 13).

As the concept of "aesthetics" sought to validate one's existence in the material world, it began to obscure the distinction between pleasure and pain. Addison's revision of Locke suggests that pleasure is not the binary opposite of pain, but rather exists on a continuum with pain. In the writings of Sade and Maturin--indeed, in the entire mode of Romantic agony-that continuum presents itself as a pleasure in pain and, more interestingly, as a pain in pleasure. For the sake of clarity, we can reduce the argument to a syllogism: aesthetics validates feeling; the greater the feeling, the more aesthetic the experience; pain is the most intense of all feeling: therefore, pain is the most aesthetic experience we can have. As I have already noted with Byron, the "great object" in the late eighteenth-century post-Lockean tradition--that which philosophy was seeking to affirm--was sensation.

However, to see pleasure in aesthetic excitation of all forms is to do so at one's peril, for the boundary between pleasure and pain is a precarious one. I have already noted how, in Burke's Enguiry, pain was stronger than any other experience, including pleasure. For Burke, pleasurable pain, the pain that can lead to the sublime, "has no resemblance to absolute pain, 
which is always odious, and which we endeavor to shake off as soon a!s possible" (p. 37). Absolute pain. as experience tells us, is always unpleasant. Moreover, it is an aesthetic experience that threatens to render us unconscious, oblivious to any sensation or aesthetic experience. Pain is both an aesthetic: intensity and an aesthetic vortex. It takes on that curious status of being too much feeling and not enough. It threatens the very aesthetic continuum of which it is a part. My thesis, then, is that writers at the turn of the nineteeth century were constantly trying to negotiate the boundary that kept pain "aesthetic"--that is, that kept it able to be felt, without allowing it to destroy itself by its own excesses.

The threat which excessive feeling (ie. pain) provided to its own continuum constitutes the fundamental irony which I want to trace in Romantic fiction. At the same time as corporeal sentience was being validated by aesthetic theory, it was being subjected to full frontal attacli from other enquiries, the aesthetic among them. The late eighteenth century was the age of an emphatic reform in the management of physical sentience, a reform whose primary agenda was to rid the world of unnecessary pain. In utilitarian judicial theory, for example, sweeping changes in the procedures of punishment sought to reduce pain and corporeal affliction, thereby replacing torture and flogging with more humane, gentler methods of correction.13 Perhaps the most paradoxical development in this reform was the emerging popularity of the guillotine--the very symbol of French 
Revolutionary barbarity--named after the French physician J.I. Guillotin who recommended it to the Revolution as a humane, efficient, painless method of execution.14 This emphasis on "humane" procedure made the execution akin to a surgical procedure, $2 s$ and connects judicial pain-avoidance to changes in medicine as well. The late eighteenth-century, targeted as the birth date of modern medicine, 16 saw as its major contribution to the history of health the development of effective, clean anesthetics which would render surgery painless. Indeed, as Foucault and David B. Morris point out, 17 medicine took the form of a "master discourse" in defining the healthy body against the painful body. And finally, the move to eradicate pain was making itself felt in thinking about theatre, spectacle, and artistic production. As we shall see with Shelley and Byron, the violence of late eighteenth-century melodrama, although popular with mass audiences, was distasteful to a new aesthetic demand for subtlety and psychological realism. This distaste for violence was mirrored in Wordsworth's disdain for the German influence on the Gothic novel. Such a disdain depicts a move in the Romantics away from the body's immediacy and toward a redefinition of "aesthetics," one focussed on the abstract, the ideal, the disembodied--the "sublime" in Burke's and Wordsworth's sense of intense feeling. And what the debate on stage violence ultimately represents is the existence of the paradoxical forces suggested by the aesthetic: it signals a boundary between the 
aesthetic as that which is rooted in the body, and the aesthetic as that which is opposed to the body.

I am suggesting, then, that the late eighteenth century devoted remarkable energy to thinking about the continuum of. pleasure and pain, and to the way that continuum could collapse into a pleasure in pain or a pain in pleasure. Moreover, this thinking co-existed with a move toward the eradication of the very existence of pain. These contradictions, I believe, emerge from the slippery definition of pain itself, a slipperiness which the eighteenth century then bequeaths to us as paradoxes in thinking about pain. Burke tells us that actual physical pain is "always odious," and in no way a pleasure, but such a preclusion was not so easy for eighteenth-century aesthetic theory. As the. OED tells us, pain is the "primary condition of sensation or consciousness, the opposite of pleasure [sic]; the sensation one feels when hurt (in body or mind). . ."; but it also has a "specifically physical sense: Bodily suffering; a distressing sensation as of soreness (usually in a particular part of the body)." That pain should be on the one hand "specifically physical" (what medical discourse calls "nociception," that is, the activity of nerve endings to signal tissue damage) and on thr: other hand a property of "body or mind" (and therefore very much, a matter of "perception") makes pain into something other than purely physical. Wilbert E. Fordyce, quoting Liebeskind, says that the usual way of describing pain as "physiological" versus "psychological" denotes "'a cartesian dualism [which] should have 
been discarded long ago'";18 David B. Morris identifies in the tendency to separate physical from psychological pain an "artificial division" which he calls the "Myth of Two Pains," a myth which fallaciously assumes that the experience of pain is separate from the sufferer's understanding of it.19 The discarding of this myth has manifested itself in a number of ways: like Fordyce's, medical treatises on pain since the eighteenth century no longer entertain the notion of a physical pain that is not to a significant degree mediated by the patient's culturally determined understanding of that pain; ${ }^{20}$ the constructivist standpoints in literary and critical theory since Foucault discuss bodily sensations as products of social discourses that define, regulate, and to a degree create those sensations in the conscious or politically unconscious subject; and literary criticism (especially that of Romantic fiction) elides the physical aspect of pain with the emotional, so that "human suffering" comes to denote the mixture of nociception and perception. Since the 1750s, then, pain has been re-mapped as a dialogue between body and soul.

But while we may no longer see pain as a purely physical phenomenon, we do, I would suggest, continue to accord it a dualistic status in the way we describe it. "There is only one antidote to mental suffering," wrote Karl Marx in Herr Vogt, "and that is physical pain."2 what Marx indicates here is that we treat nociception very differently from perception; we usually fear a broken leg with more intensity than we do a broken heart. 
In her 1985 book The Body in Pain: The Making and Unmaking of the World, Elaine Scarry suggests that, regardless of the physiology of pain, the experience of pain reinstates a Cartesian antagonism between body and mind by attacking the "self" with pain: "The ceaseless, self-announcing signal of the body in pain, at once so empty and undifferentiated and so full of blaring adversity, contains not only the feeling 'my body hurts' but the feeling 'ny body hurts me"" (p. 47). Our English word "pain" comes from the Latin poena, meaning pena!ty or punishmert. The body in pain attacks the self that recognizes that pain. This sense of being attacked by one's own body, says scarry, explains why metaphois for pain are so often those of weaponry, assault, and violatiull (pounding, burning, tearing). Pain evokes an antagonistic relationship between the body and the self at the same time that it allows no distinction between body and self: I hurt and I am being hurt; I hurt myself. Thus, what pain effects is a retur. of the body to a pre-cartesian body--where mind and budy arf: inseparable--at the same time that it pits the mind firmly against the body. Pain confounds one aspect of dualism (the primacy of mind over body) by evoking another aspect of dualisil (the body's perceived estrangement irom the self). What is perhaps most singularly remarkable about this confusion, then, is the way pain destabilizes three hundred years of western Cartesian thinking, in which the mind is separated from and privileged over the body. 
I do not wish to suggest here that physical pain is ever free from cultural mediation, or that we can have direct access to nociception that is not in some way framed by the symbolic. That kind of dualism, physicians tells us (and rightly, I think), is no longer tenable, and is not my interest in this study. But I do believe that pain, as it attacks our bodies, reinstates in our perception of it a dualism which, by trying to control (through the mind's dialogue with the body), we end up reinforcing (through the mind's control over the body). And as such, pain elicits a complex series of confusions about the way we think about the body. It reinstates and strengthens the slipperiness of the terminology I noted earlier. I hope in this study to make evident that such slipperiness and fluidity in definition underlie the treatment of pain in Romantic fiction, and constitute a crisis in the way authors think about pain. But more important, it throws into crisis the very identity of the individual that is simultaneously validated and threatened by the experience of pain. Thus, by focussing on physical pain, and by separating it from a more general Romantic agony of mental suffering, I hope to trace a line of enquiry that explores more fully the paradoxes engendered by pain at the end of the eighteenth century. My question is similar to that of Diana Fuss in Essentially speaking: she suggests that, in thinking about gender, we move the constructivist debate away from the "How is the body articulated by the social?" toward asking "How is the social articulated by the body?."2 2 My question here is not "How 
did the late eighteenth and early nineteenth centuries articulate the experience of pain?" (which, while important to this project, is closer to Foucault's formulation of the question), but rather "How did pain articulate the eighteenth-century experience?" What kind of aesthetic discourse was born of the body?

I I

The degree to which pain articulated the social at the end of the eighteenth century began with the way it re-organized the landscape of the human body and its responses to stimulation. Until the early 1750 s, pain was understood through the model provided by Descartes. For him, one's reaction to pain was a purely mechanical process, a reflex action. In his scheme, the soul was immaterial, and made contact with the body through the pineal gland at the base of the brain. From there, it directed animal spirits toward the part of the body receiving the painful stimulation. L.J. Rather offers a lucid summary of Descartes's account of the body's encounters with potentially dangerous or threatening stimuli:

According to Descartes, the observation of sometring strange or threatening sets up a movement of animal spirits (material substances in the Cartesian scheme) in the nerves that (a) turns the neck and head, and moves the arms and legs appropriately, (b) moves the pineal gland in such a way as to incite fear or anger in the mind (not in the brain), and (c) in the same mechanical, reflex, fashion alters the size of the 
orifices of the heart and thus alters the "rarefaction of the blood". . . . The movements of the body are not primarily caused by the mind, but are rather of the nature of the reflex... . 23

The experience of pain, of direct nociception, followed the same path. Because the soul is immaterial, it could in no way dictate involuntary motions of the material body, such as that of drawing one's hand out of a flame, or even of contracting the lungs in breathing. Instead, the soul activated the pineal gland, whose secretion of animal spirits would direct the body toward the proper protective behaviour. For Descartes, then, one's response to the stimulus of pain was a purely mechanical physiological response, mediated through the pineal gland, and in which the mind and soul played no direct part; they merely engineered the mechanisms by which a reflex response could take place. This mechanism constituted the most widespread source of understanding of pain until the eighteenth century.

But for many physicians, the reflex model of pain behaviour was unsatisfactory, and required further study. The most famous of these physicians was Robert Whytt. Born in 1714 in Edinburgh, Whytt became the first physician to challenge seriously Descartes's theory of the reflex. For Whytt, Cartesian mechanism was too systematic and general. Descartes's reflex model may have explained how individual body parts respond to pain, but it did not account for the role which emotional disposition seemed to play in the behaviour of symptoms. Nor did it explain why 
disparate body parts seemed to respond to pain that did not threaten them directly--why, for example, nausea often accompanies headaches. In other words, Cartesian mechanism failed to explain why the body seemed to act interdependently. In 1751, Whytt's Essay on the Vital and other Involuntary Motions of Animals began to explore the principle of human sentience as it relates to neurophysiology. What whytt would eventually propose was a re-evaluation of Descartes's centralized, alienated soul. For whytt, the soul was not sequestered in the fortress of the pineal gland, there to issue orders but never to take part in battle; rather, whytt hypothesized that the soul extends from the brain down the spinal column and to all parts of the body. This. principle he called "coextension," to contrast with Descartes": dualistic "thought" and "extension,"21 and he suggested through it that the body is interconnected at the level of physiology.

From this decentralizing model, whytt advanced his famous "sentient principle." For Whytt, "nerves are endued with feeling, and. . there is a general sympathy which prevails through the whole system; so there is a particular and very remarkable consent between various parts of the body."2s This "general sympathy" gathers information from all parts of the body and discharges stimulation to all parts of the body, so that "every sensible part of the body has a sympathy with the whole . . (p. 493). The movement of spirits is no longer unidirectional, but rather dialectic. All stimulation is perceived by the mind, as Descartes maintained, but since "the 
mind is only affected thro' the intervention of the optic and auditory nerves. . ." (p. 493), it too is affected by physical stimulation, and can no longer be considered to dominate the body's experiences. Nothing exists in the mind, to modify Berkeley's claim, but as it is perceived by the physical body. The sentient principle, then, overturned the hierarchically structured image of the body as a Cartesian system of mechanistic reflexes, and replaced it with the image of the body as interconnected, feeling entity. In other words, whytt's medical discoveries proved that "the old distinctions between animus and anima--mind and soul--or between thinking and feeling, were misleading and unnecessary. . . "26 By the end of the eighleenth century, the body had become a more democratic, dialogic site in which all members contributed to overall health.

What is most important for my purposes here is the notion that "sympathy" is physiologically based. Galenic medicine had discussed sympathy, but only as the product of moving humours throughout the body. As John Mullan notes, whytt firmly connects the term "sympathy" not just to the bodily organs, but to a kind of mutual awareness that these organs share with each other.27 With whyt--and a group of physicians doing similar work at Montpellier, France28--sentience is no longer a monologic reflex. Rather, corporeal feeling becomes part of an internal integrity, wholeness, and unity of the body, one that can be rendered visible by the physician's penetrating gaze.29 No longer a victim of an alienated and immaterial consciousness--a superstitious 
ancien regime of metaphysiology--the body contributed to its own aesthetic awareness and make-up, by contributing to the signals which constituted its psychology, and thereby contributing to the psychology that constituted the sentient signals it received. Physical sentience became the raw material of sympathy--that joining together of all aspects of the body in fellow-feeling. Given the medical enthusiasm for a well-ordered, harmonious, and sympathetic body in the eighteenth century, it takes little effort to read that image of the body as a proposed model for the social body as well. As L.J. Jordanova remarks, 30 the image of the body as naturally sympathetic became an important model both for the family and for the body politic. The physiological beginnings of social sympathy are, once again, founded in whytt. From the "remarkable sympathy" which whyt observed between various parts of the body, "there is still more wonderful sympathy between the nervous systems of different persons, whence various motions and morbid symptoms are often transferred from one to another, without any corporeal contact. . ." ( $p$. 583). Physical symptoms become "infectious" as they imprint themselves on the sensorium commune. For Descartes, the immaterial soul's alienation from the body effectively isolated and encapsulated subjectivity. This isolation, when transposed to public life, formed the social basis of selfishness and individualism (that would get picked up and developed by thirktels like Hobbes and Mandeville). For whytt, on the other hand, the interconnectedness of body and brain--of object and subject.- 
ensured the interconnectedness of all animate, sensitive beings.31 Whytt's theories provided "empirical physiological evidence. . that it is through sympathy that human beings are basically able to communicate with each other."32 Toward the end of the century, John hunter would make a similar point. Hermione de Almeida states the case:

John Hunter's teachings on the 'sympathy' between organs and parts commonly observed by clinicians in the hospitals of England led him in 1794 to address a parallel 'sympathy of the mind' vital to the study of life by the creative artist or physician: "One of its chief uses is to excite an active interest in favour of the distressed, the mind of the spectator taking on nearly the same action with that of the sufferers, and disposing them to give relief or consolation: it is therefore one of the first of the social feelings. . . ." (p. 35)

Thus, democratized physical sentience underwrote democratized communal sentience. At the level of the medical body, sympathy makes society possible.

The sympathetic body--both in its private and public aspects--not only carved out a new definition of the medical subject, but a new ontological, philosophical definition of subject as well. Human sympathy established in its moral implications the foundations for Moral Sense Philosophy which, in the eighteenth century, became Cartesian rationalism's most 
vigorous opponent. I do not have the space here to delineate all the ways that Moral Sense Philosophy assaulted Cartesian and Lockean premises: excellent explanations can be found in Charles Taylor's sources of the Self: The Making of the Modern Identity (see 248-349), Mary Poovey's "Ideology and The Mysteries of Udolpho," and stephen D. Cox's "The Stranger within Thee": Concepts of Self in Late Eighteenth-Century Literature. ${ }^{3} 3$ whal I do want to emphasize, however, is the shift in thinking that was effected by the theorizing about the corporeal, physical sentience that underlies communal sympathy. It is this shift, I want to suggest, that marks a crucial change in the way community was thought to be made possible, and in the literary modes which attempted to reflect this possibility.

Perhaps the most famous of the Moral Sense Philosophers after Shaftesbury is Adam Smith. In his 1759 Theory of Mora? Sentiments, Smith argues that while we can have no direct knowledge of someone else's afflictions and pairs, [b]y the imagination we place ourselves in his situation, we conceive ourselves enduring all the samt: torments, we enter as it were into his body, and becom: in some measure the same person with him, and thence form some idea of his sensations, and even feel something which, although weaker in degree, is not altogether unlike them. ${ }^{31}$

In The Surprising Effects of Sympathy: Marivaux, Rousseau, Diderot, and Mary Shel ley, David Marshall notes a contradiction 
in Smith: for Smith, says Marshall, "sympathy is based on an act of the imagination in which we represent to ourselves an image of what we think the other person is feeling.. . "35 sympathy is fraught, then, with the possibility that another's feeling might be nothing but our own self-interested construction. In his discussion of Diderot, Marshall summarises the main thrust of his book:

- . since we are unaware of what other people feel, we can appreciate what takes place inside them only if they represent the exterior signs and symptoms of their sentiments. The danger in this situation is finally not that we might not believe other people, but that we might not believe in them. (p. 134)

Smith himself says that "we have no immediate experience of what other men feel[;] we can form no idea of the manner in which they are affected, but by conceiving what we ourselves should $f e e l$ in the like situation" (p. 9). Rather, Smith writes,

the enotions of the spectator will still be very apt to fall short of the violence of what is felt by the sufferer. Mankind, though naturally sympathetic, never conceive, for what has befallen another, that degree of passion which naturally animates the person principally concerned. That imaginary change of situation, upon which their sympathy is founded, is but momertary. The thought of their own safety, the thought that they 
themselves are not really the sufferers, continually intrudes itself upon them.... (p. 21)

For the Moral Philosophers, of whom Smith is the pinnacle, failure in sympathy is ultimately a failure in imagination. One cannot imagine another's pain; ergo, one cannot feel it. What you don't know won't hurt you.

However, at the same time that smith is betraying doubt as to the possibility for imaginative sympathy, the developing concept of aesthetics is trying to find ways out of that doubt. While Marshall is right to argue that the attempt by Moral Philosophy to undo Cartesian alienation was doomed to failure, that does not mean that thinkers gave up trying to find ways to construct community. I have already noted Robert whytt's discussion of physical sympathy, which argued a thoroughly involuntary construction of community: one was simply infected by another's symptoms; one's ability to imagine another's pain did not enter into the equation whatsoever. This more complete interchangeability of bodies is also Edmund Burke's point in his Enquiry written, like Smith's Theory of Moral sentiments, at the end of the 1750s. While Burke is not a Moral Philosopher, 36 he is interested in the construction of sympathetic community. And a.s he imagines possibilities for disinterested community, he draws upon the body to authorize them:

It is by [sympathy] that we enter into the concerns of others, that we are moved as they are moved, and are never suffered to be indifferent spectators of almost 
any thing which men can do or suffer. For sympathy must be considered a source of substitution, by which we are put into the place of another man, and affected in many respects as he is affected.... . (p. 44)

By placing ourselves in someone's situation, by substituting our bodies for the bodies of others, we enact at the physical level that familiar cliche, "I know how you feel." Thus the crisis in Moral Philosophy is somehow alleviated by a new "aesthetic" definition of sympathy which writers like Hazlitt (in "Self-Love and Benevolence: A Dialogue") and Shelley ("A Defence of Poetry") would argue as passionately in favour of as sade and Maturin would argue against. By the end of the eighteenth century, the sympathetic body in medical and aesthetic philosophy was the site which proclaimed the potential imaginative transference of self into other, a transference so powerful that it would ki 1 Henry Mackenzie's Man of Feeling who felt another's suffering too fully. With this new aesthetic, one which Brissenden identifies with the birth of the cult of sensibility (p. 104), the unified, sympathetic body was invested with the power to heal the subjectobject gap. ${ }^{37}$

While aesthetic philosophy may have undertaken to rewrite the subject-object gap which Descartes had opened, it did not forget the Cartesian dualism from which it sprang. We have seen through Marshall the anxiety expressed by writers early in the century that sympathy was an act of imagination, and often doomed to failure. Burke also leaves an escape clause, one that keeps 
him from getting too close to the pain with which he claims to sympathize. For Burke, the idea of pain is a "delight" only by virtue of the perceiving sur ject's distance from it, his contemplation of it. For when

pain and danger press too nearly, they are incapable of giving any delight, and are simply terrible; but at certain distances, and with certain modifications, they may be, and they are, delightful . . . (p. 40)

A comparison to Smith here is illuminating. For Smith, "we have no immediate experience of what other men feel"; there is never enough feeling. For Burke, on the other hand, sympathetic pain can "press too nearly"; we can feel it too much. And when pair. presses too near, it evokes that desire for self-preservation which, for Burke, destroys community (p. 44). But when pain is experienced at a distance--through literature, or imaginative projection, or any experience that does not threaten us directly --we feel a sense of delight:

If this passion [ie, the sympathetic sharing of pain] was simply painful, we would shun with the greatest care all persons and places that could excite such a passion. . . But the case is widely different with the greater part of mankind; there is no spectacle we so eagerly pursue, as that of some uncommon or grevious. calamity; so that whether the misfortune is before our eyes, or whether they are turned back to it in history, it always touches with delight. (p. 46) 
For Burke, aesthetic distance is necessary because the ability to feel another's pain is all too strong: for that reason, the experience of another's pain must be regulated and diminished. Like Smith, Burke constructs a boundary between pain and pleasure, and between sympathetic iden: $f$ ication and distance, but he does so for very different reasons.

Thus, the problem in Romantic fiction as a literature of sensibility seems to be that the body makes possible an interconnection of subject and object, but that it does so by inducing pain in the observer who wishes to unite with the pained subject. From this threat, I would suggest, comes the generating principles of the Gothic's fascination with and treatment of pain. Gerald Bruns describes the "limits of Romantic hermeneutics" as the recognition that it is impossible to "[exceed] the finitude of reason that withholds the other from me - . [which] is born of the impossible desire to possess the self-possession of the other, knowing the other from the inside out, with the self-certainty of Descartes's self-experience, not doubting the other as one not-doubts the self." This limit, Bruns hints, is drawn at the body, and by the body: "The grave, like the body, seals us off from the other": "[w]e cannot know another's pain."38 For Elaine scarry, these hermeneutic limits are the necessary product of pain, which invokes the "absolute split between one's sense of one's own reality and the reality of other persons" (p. 4). In this sense, the limits of Romantic hermeneutics are similar to those which Marshall locates in 
Marivaux. But I would suggest an even more complicated state of affairs for literary renderings of pain after the 1750s. The literature of Sensibility, and Romantic fiction in particular, fostered the myth that pain could be shared through the medium of the sympathetic body. Thus, pain became a proclamation of ontological presence both for the victim and the spectator of pain, the distinction between whom could no longer be said to exist. As Elaine scarry argues, pain is "so incontestably and unnegotiably present. . . that 'having pain' may come to be thought of as the most vibrant example of what it is to "have certainty'. . " (p. 4). However, as I shall discuss more fully in chapter two, this shared pain deconstructs its own community, since by centering itself in the observer who shares it, it becomes "the most vibrant example" of an individual experience, one which is not communal at all. Hermione de Almeida argues that the social awareness of pain's tyranny at the end of the century made the sympathetic voice of the poet--in her study, Keats--all the more necessary as intermediary spokesperson or ventriloquist for the private experience of someone else's pain (pp. 56-57). But in my analysis the attempt to construct this coherent community through the fluidity of the sympathetic body is always troubled by the vicissitudes of sympathetic pain as they are inscribed on the body. Pain is always and never a communal moment. ${ }^{39}$

By this logic, pain constructs a binarism of privacy and publicity that its theorists sought to overcome: whereas observed 
pain is at the heart of Moral Philosophy's theories of substitution and community, it is really that which guarantees solitude, individuation, and privacy. This dual role helps explain why pain became such a fascination at the end of the eighteenth century. Plagued by the attempt to reconcile individual privacy with social communily, philosophers from Locke and Hume on tried to find a system which could connect one's feelings to the outside world of others' feelings, but without compromising the private interiority of those feelings. As Frances Ferguson explains, debates about population, the growth of cities due to the development of industrial capitalism, and the emphasis on personal and private aspects of individual consciousness generated a feeling that one's self could get lost in the crowd, that one's individual consciousness was competing against many. individual consciousnesses.10 sympathy, then, became the perfect mediation. It acted as a way of feeling oneself in the world--an "aesthetic," in Terry Eagleton's sense-which facilitates social behaviour at the same time that it allows a person to act autonomously.41 For stephen D. Cox, "sympathy" both destabilizes the solitary cartesian prison by melting the boundary between the inside and the outside, and guarantees the preservation of that inside/outside division: sympathy's emotive experience (Burke's "delight," Smith's "effect") assures a distance and protection to the perceiving self that is enjoying this experience. The social fabric or body politic here is built on sensibility and the aesthetic, but it is 
constantly being threatened by the individualist protection of insensibility and anesthesia. In the chapters that follow, then, I want to discuss the way the hermeneutic limits as they are dictated by the body both invoke a community and at the same time destroy it.

\section{I I}

If sympathetic substitution is the agency by which we reconcile our public life with our need for privacy, then sentimentalism has an overtly political aspect. In the late eighteenth century, this political aspect of the pained body was extremely important (but not limited) to representations of the French Revolution. Long before the Revolution exploded on 14 July 1789, Cesare Beccaria, the most famous of enlightenment European judicial reformers, declared in his essay on_crimes and Punishments that "No lasting advantage is to be hoped for from political morality if it is not founded on the ineradicable feelings of mankind."12 These "ineradicable feelings," as we have seen, not only legitimate the subject in a previously Cartesian rationalist universe, but they connect that subject to all other subjects as well by the substitution of painful bodies. For Carl woodring, this ability to imagine oneself into another's experience constitutes "the politics of English Romantic poetry." For the Romantics, in Woodring's analysis, the new community that would replace the ancien regime, its tyrannical superstitions, and its mind-forged manacles, in Blake's phrase, was possible 
only through the ability of one to place oneself imaginatively in another's experience.13 But as we have seen, the possibilities for imaginative substitution--and hence, political affiliation-are not only most strongly invited by the body in pain but are also precluded by the body in pain. Thus, I want to outline in the next few pages how sentimental appeals to pain both furthered the Jacobin cause of much Romantic fiction, yet also undercut that same cause.

To the degree that the Revolution was fueled by Rousseau's On the Social Contract, it sought a political community based on the "ineradicable feelings of mankind." Rousseau sought to unlock the chains into which every citizen is thrown after birth by reducing unnecessary force and legal conscription. Law, for Rousseau, was preceded by sentiment, "what everybody has already felt" without "art and mystery."14 This doctrine of sentiments, which is natural, although corrupted, in social man, unites the multitude into one body, and assures the individual freedom of each body within the social contract (p. 150). Thus, as Brissenden argues, the "French Revolution, at least in one of its aspects, was an attempt to create the conditions under which men would be free to express their good impulses. . ." (p. 150). Brissenden believes that the moral truths and social programs expounded in the French constitution are grounded, like eighteenth-century aesthetics, in feeling: that is, they were grounded in the belief that man's capacity to act morally is related to the degree of 
psychological and physical sensitivity with which he can spontaneously respond to the world about him, related, in a word, to his sensibility. With this belief went the hope that if people were allowed to exercise their sensibilities freely they would act in a 'humane' way. (p. 57, emphasis original)

This physical response, this "aesthetic," then, is overtly political, and overtly revolutionary. The voice of the heart (which, by the late part of the century is called the "sentimental," and becomes indistinguishable from "feeling") cries out for the fellow body in distress and thereby confirms for us our "solidarity with our fellow creatures."1s This naturally sympathetic voice, that which arose from shaftesbury and his school as a "natural morality," guaranteed the primacy of "natural rights," not only for writers like Thomas Paine and Mary Wollstonecraft, 16 but even for the Marquis de Sade. In his attempts to persuade Frenchmen to become Republicans, he argues (atypically) that "happiness consists in rendering others as fortunate as we desire ourselves to be," that the Republican fabric is woven with threads of natural feeling and material improvement.17 This interweaving, which comprises the rhetoric of Revolutionary propaganda, is perhaps most famously displayed in Wordsworth's reminiscences on France: as he walked through Paris with his friend Beaupuis,

$$
\text { we chanced }
$$

One day to meet a hunger-bitten Girl, 
Who crept along. . . in a heartless mood of solitude, and at the sight my Friend In agitation said, 'Tis against that Which we are fighting. . . ."48 "That" is the highly charged body in pain, the victim of the ancien regime. Pait: is the product of political tyranny.

But "that" can be more than one victim; it can be any victim, including the French king himself. Beaupuis's appeal to sentiment as political rhetoric demonstrates an emotional affect that anti-Jacobin critics of the Revolution were also able to exploit. As Ronald Paulson notes, 19 reactionary English Tories used images of French barbarism to argue the antijacobin cause: the French, after all, paraded decapitated heads on poles, the French cheered during public executions, and worst of all (according to Burke), the French invaded the sacred bed-chamber of Marie Antoinette and attempted to stick her full of sabers.50 Pain could be used not only to support one's revolutionary sympathies, but also to argue against Revolutionary sympathies. In the Reflections on the Revolution in France, Burke concludes his long tirade on the attack on the Queen by discussing why he feels the way he does. In so doing. he outlines a politics of sentiment:

Why do I feel so differently from the Reverend Dr Price, and those of his lay flock, who will choose to adopt the sentiments of his discourse? - For this plain reason--because it is natural. I should; because 
we are so made as to be affected at such spectacles with melancholy sentiments upon the unstabl: condition of moral prosperity, and the tremendous uncertainty of human greatness; because in those natural feelings we learn great lessons; because in events like these our passions instruct our reason; because when kings are hurl'd from their thrones by the supreme Director of this great drama, and become the objects of insult to the base, and of pity to the good, we behold such disasters in the moral, as we should behold a miracle in the physical order of things. (p. 175)

Whereas pain and violence catapult the young wordsworth, Coleridge or Thomas paine into revolutionary political fervour, they make Burke (and the older Wordsworth and Coleridge) all the more suspicious of revolution. Pain and violence conjure up different notions of the "natural man": in Paine, it is the man moved by sentiment to change the political structure of oppression, to effect a "revolution" that will be a complete break from the past; in Burke, pain and violence move one to return to the order of tradition and natural self-control, to effect a "revolution" that is a return.31 clearly, the sentimental response to pain is problematic, in that it can work. for or against a political movement, depending on whom you cast in the role of victim. It could be used by both Jacobins and anti-Jacobins alike to further the emotional appeal of their cause, and at the same time, as Janet Todd tells us, its 
unpopularity could be exploited as a way of accusing the other side of acting unreasonably.32 Thus, by the end of the eighteenth century, "sentimentalism" came to demonstrate not only false, hypocritical, affected, or superficial feeling, as Brissenden notes ( $P .7$ ); it also suggested a highly politicized, highly effective, and highly dangerous mode of argument, one that could win one's case rhetorically by transferring the moral weight of the pained body to the side one wants it to be on. Pain presents a confusion because, among other things, it invites us to sympathize physically and emotionally with someone whom we might abhor morally and politically--someone like Louis XVI or Marie Antoinette, the objects of Jacobin scorn. similarly, pain presents problems because it is sometimes seen as a necessary result of fighting injlistice; the infliction of pain is essential to fighting the tyranny that inflicts pain on others. The necessity of inflicting pain, and the moral questions it raises, underlie much Romantic fiction, like Shelley's The Cenci. or Godwin's Caleb Williams, and also Jacobin tracts such as Paine's 1791-2 The Rights of Man, Wordsworth's 1793 Letter to the Bishop of Llandaff, and Godwin's 1793 Enquiry. Concerning Political Justice. These writings demonstrate the problem of determining whose pain we should feel and whose pain we should remain insensible to. Wordsworth, for example, chides Richard Watson, Bishop of Llandaff, thus:

At a period big with the fate of the human race, I am sorry that you attach so much importance on the 
personal sufferings of the late royal martyr and that an anxiety for the issue of the present convulsions should not have prevented you from joining in the idle cry of modish lamentation which has resounded from the court to the cottage... . [Bishop M. Gregoire] declared at the opening of the national convention, and twenty-five millions of men were convinced at the truth of the assertion, that there was not a citizen on the tenth of august who, if he could have dragged before the eyes of Louis the corse of one of his murdered brothers, might not have exclaimed to him, Tyran, voila ton ouvrage.53

The sentiment here, if it can be so-called, is Godwinian and utilitarian: "It is right that I should inflict suffering, in every case where it can be clearly shown that such affliction will produce an overabundance of good."34 Unlike Wordsworlh, Paine is at least willing to invoke the humanity of Louis XVI, but only to write it of by claiming that the Revolution "was not. against Louis XVI, but against the despotic principles of the government. . ",55 as if that should make Louis's ghost rest any easier. Paine's careful separation of the abused human body and the abused body politic forces him to make another careful distinction in his definition of proper sympathy. He accuses Burke of not expressing "the language of a heart feeling as it ought to feel for the rights and happiness of the human race," but rather of constructing "tragic paintinọ" which are "very 
well calculated for theatrical representation, where facts are manufactured for the sake of show, and accommodated to produce, through a weakness of sympathy, a weeping effect" (pp. 71-72). The "weeping effect" of sympathy is an unnatural response, a pale imitation of the language of the heart. Natural sympathy, then, presumably includes the utilitarian recognition that regicide is acceptable and preferable to the status quo. Sympathy here has to do not only with political sensibility., as Brissenden would have it, but with political insensibility as well.

If sympathy as fellow-feeling can perform the dual function of telling us what to feel and what not to feel politically, then it furthers the mediation between the public and the private that I noted earlier. Paine's ambivalent sympathy, marked as it is by binarism of sensibility/ insensibility, is representative of a larger structure of sentiment and stoicism that runs throughout the im gery of the Revolution. Ronald Paulson notes a central paradox in aesthetic representations of the Revolution: while the sans-culottes sought as their ultimate goal to replace previous definitions of order and monarchial structure with a democratic system founded on natural morality, they employed a Neo-classical mode of representation to figure that replacement. Suspicious of the rococo decadence and frivolity of Louis's court, the revolutionaries, argues Paulson, brought order and harmony to their newly envisioned political system through a classical raference that both structured and legitimized the republic ( $p$. 36). For Dorinda Outram, this stoical nostalgia--such as one 
sees in the paintings of Jacques Louis David--was not only essential to the superstructure of the Revolution, but also to the individual within the new body politic. For outram, the repeated references to stoicism in Revolutionary productions were intended to provide a model of self-government which the individual could emulate (p. 36). And essential to this selfgovernment was the citizen's withdraw.:l from the object world. He had to be freed from a sensibility which, as the previous discussion makes clear, obfuscates one's political alignments and one's physical sympathies.36 "The "Stoicism" of the Revolution," Outram argues, "is about the definition of an autonomous self through an autonomous, impermeable, controlled body" (p. 81). This impermeable body, what Norbert Elias called the "homo clausus,"s7 constructed a dialectical citizen, one who, like Wordsworth, was moved by the sympathetic impact of the hungerbitten girl, but one who, again like Wordsworth, found the deepest and most profound sentiments in privacy, "in the place/ The holiest I knew of, my own soul."58

IV

To the degree that much Romantic fiction constructs the hero as "homo clausus" in order to isolate him/her from the body in pain in general, and from the Revolution in particular, I want to suggest that it constructs the reader of the Gothic novel in a similar way. We are already familiar with the argument that Romantic fiction is a literary expression of the desire to connect subject and object: in Natural Supernaturalism, M.H. 
Abrams discusses the importance schiller placed on art's unification of the unself-conscious subject with the selfconscious subject-as-object;39 Rene Wellek argues that Romanticism is the attempt to reconcile the perceiving subject with the perceived object world;60 as John Jones notes, Coleridge's work is permeated by schelling's thesis that art makes the external internal and the internal external.61 To the degree that Romanticism arises from an aesthetic, sentimental tradition in which political community is founded on individual sensation, it becomes what Janet Todd describes as "a kind of pedagogy of [the senses] and of the physical reaction that [those senses] should produce. . ." (p. 4). However, it is also not new to suggest that this attempt at connection is problematic for the Romantics, or that the Cartesian gap can never be bridged by any self-conscious strategy: James Averill traces the effect on Wordsworth of a literary tradition which emphasizes one's own intense feeling in the face of human suffering, arguing from this that once we recognize our own feeling, we can never hope to get back to an unself-conscious identification with the object in distress;62 in their discussions of painting and theatrical spectacle, Michael Freid and John Bender talk about qualities of self-conscious voyeurism that are intended to highlight the spectator's status as observer, as standing outside the actions of the artistic subject;63 William Patrick Day relates this selfconscious voyeurism to the dynamics of parody, which for him is the underlying mode of the Gothic and its distancing of the 
reader.64 While this debate is firmly established in criticism of the late eighteenth-century, I would suggest that it does not take into account the dynamics of imagining pain as I have outlined them above. Romantic fiction, in its fascination with pain and physical limitaticn, registers a crisis of sentimentalism which both engages and distances. Someone else's corporeal sentience always demands a sentient response from the spectator, yet it also always invokes the awareness of the limitations of that sentient response. In this sense, corporeal sentience is "aesthetic" in both aspects of the word: it points to a feeling of physical being-in-the-world at the same time that it disembodies and abstracts that physical being.

Up to this point, I have tried to explore the eighteenth century's fascination with pain in terms of the contradictions it presented. These contradictions--pleasure/pain, publicity/ privacy, sensibility/insensibility, sentimentality/stoicism--cut across a number of fields of enquiry, including the aesthetic, the ontological, and the political. Given this rich and complicated intersection of problems, I want to define as clearly as I can what I mean by "the politics of pain," the subtitle of this study.6s My definition is three-fold. The first is a cultural politics. In Romantic fiction, pain demonstrates a general bourgeois interest in constructing the individual self that is part of but separated from the larger society. This construction, I want to argue, is achieved by exploiting the vicissitudes that sympathetic pain embodies: pain signifies both 
a threat to hea!th--whose logical extension is death--and an assurance of healti--in that it guarantees that $s /$ he who is feeling it is not dead. By blurring the gap between the perceiving subject and the pained object, sentimental Romantic responses to pain create a community of shared pain. But, as I have already noted, pain is ultimately a completely individual experience which isolates the sufferer from all others. Pain elides Cartesian individualism only to end up re-inscribing it.

The second sense of the politics of pain comes from the first, and emphasizes the political implications of the breakdown in dualism. Given the slipperiness of a definition of pain, a definition of its politics becomes difficult to pin down. As I have already shown, medical theorists and physicians since the eighteenth century have discarded what David B. Morris calls the "Myth of Two Pains," the separation of nociception, or tissue damage, from the patient's culturally determined perception of it. While this mind/body relation must be assumed, it also presents political problems. To argue that pain does not exist but as it is perceived, and that cultural, class, and gender differences always shape the way pain is experienced, is to open up the possibility for differences in the political signisicance of pain. As Morris himself argues, racist whites in nineteenthcentury America assumed that black slaves were less capable than they of feelings of and responses to pain; thus, slaves could be whipped without the moral implications that accompany violence being inflicted on another human being (p. 39). By privileging 
the mind--and its alleged capabilities and incapabilities regarding the perception of pain--whites could then justify the oppression of the body. As I will demonstrate in chapter foll, this problem is replicated in Gothic discussions of torture, where the "criminal"'s body becomes useful to the degree that it can help to expose and to regulate the mind. Because the mind can be used to justify abuse on the body, I would argue that the interrelationship between mind and body, while intending to destroy mind/body dualism, actually risks reinforcing this dualism all the more. Politically induced pain--as in torture, war, or revolutionary violence--is intended to exploit the borly's connection to the mind, and to get at the mind by way of the body. In so doing, it ultimately attempts to reinstate the primacy of the mind as the site of truth, pain, subjectivity-in short, of "real life." Thus, I am proposing here a study of the body and physical pain as something not separate from the mind but also not able to be subsumed_by the mind, because the body is too often the site of pain in its political manifestations.

The third and final sense of the politics of pain is more partisan: depictions of pain in turn-of-the-century fiction often set the problems of pain within the context of the French Revolution (or historically distant revolutions which connote the French). These depictions use pain to exploit English responses and ambivalences toward events in France. Pain both enlists and destroys Revolutionary sympathies; it both engages the British subject (in both senses of the word) in the cause of liberation 
and isolates that subject from a Revolution that might spread to its own front yard. In other words, "politics" in this study evokes the contemporary debates about political affiliation, yet it is not meant to connote a coherent ideological position. Like pain itself, "politics" is meant to be paradoxical, selfcontradictory, and fragmented, yet at the same time real, forceful, and effective.

Thus, each of the chapters that follows raises a difierent theoretical question about the self's relation to pain, and then sets that relation within the context England's relation to revolutionary Europe. I have arranged these chapters in order of an increasing closeness to or intimacy with the pained body. Chanter two extends the framework that I have begun here by discussing the incompatibility of imagination and pain. Iike the "aesthetic" itself, this chapter talks about pain from a distance, as it is imagined in the disembodied other. Chapter three localizes the problem of imagination and pain by focussing on the English stage. At the turn of the nineteenth century, Romantic playwrights tried to construct and regulate responses to the Revolution by moving spectacles of pain off-stage, and by making the imagination the sire of revolution, or of reactionary response to revolution. The problematic response to the spectacle of suffering is then explored in a different context: the spectacle of judicial punishment. Chapter four focusses on the visibility of suffering in judicial torture, and on a crisis in sensibility that both engaged public sensibility and required 
utilitarian punishment. Torture in the Gothic novel is used to induce moral outrage against French barbarism, but only in order to isolate the individual who claims to feel the victims's pain. Torture, ultimately, confirms the sympathetic individual's isolation and safety. That confirmation of safety through the feeling of pain is explored in chapter five at pain's most intimate site--one's own sick or diseased body. In this chapter, pain is both confirmation and numbness; it is both a validation of the mind's consciousness of pain and an obliteration of that mind's power to perceive. The tenuous status which the mind enjoys here has particularly revolutionary overtones, in that "proper" political action is often determined by the degree to which the mind is controlling the body. Thus, in this final chapter we see how one's own medical, aesthetic condition is itself a political question. Each of these chapters, I hope, emphasizes the effect to which I referred earlier, that is, that pain is not only constructed by social discourses, but actually reconstructs the way discourses represent it. Pain contains the properties that precede and supplant discourse. It is not only spoken through culture; it is also the unspeakable within culture. This study attempts to show the cultural productions of that unspeakability.

Finally, a few words on what this study doesn't do. First, it does not claim to master the lives and works of authors it discusses. While I have tried to incorporate biographical and literary considerations into my analyzes of the novels, plays, 
and poems, I have not. tried to provide an arch-theory or master discourse which would offer the last word on the author in question. While in many cases the author's medical history offers striking parallels to the problem of pain in the work, my concern is the text, and the problems it raises on its own terms, and in the terms of the circulating discourses in which it was written. Second, I have not discussed all the Gothic novelists, nor all the Romantic poets. In fact, the words in chapter one which concern Blake and Keats are the last on them.66 Again, texts were chosen on the grounds of their applicability to the questions raised, and on my own personal interest in them, and not on their canonical status. And finally, this work does not treat all the questions it could about pain in the late eighteenth century; it is not the key to all pathologies. For example, there is no discussion of pain as it comes out of a protestant and Calvinist tradition--although such a discussion would no doubt illuminate the texts of Byron, Maturin, or James Hogg. Nor is there a chapter on gender politics, to which Wollstonecraft and Mary Shelley would contribute (and, I admit, which seems to be begged by the chapter on Radcliffe and Wordsworth). These deficiencies do not come out of a lack of interest, just a lack of space. All of which raises a final irony: Elaine Scarry suggests that intense pain destroys all words (pp. 19-20); conversely, it can also inspire too many. 
Notes

1.Edmund Burke, A Philosophical Enquiry into the origin of our Ideas of the Sublime and Beautiful, ed. James T. Boulton (London: University of Notre Dame Press, 1958), p. 39.

2. Mario Praz, The Romantic Agony, trans. Angus Davidson (New York: Oxford University Press, 1970), p. 27.

3. Donatien Alphonse de Sade, The Complete Justine, Philosophy in the Bedroom, and other writings, trans. Richard seaver and Austryn Wainhouse (New York: Grove Press, 1965), p. 252.

4.Lord Byron, Byron's Letters and Journals Vol. III, ed. Leslie Marchand (New York: Alfred A. Knopf, 1957), p. 109.

5.Jchn Keats, The Letters of John Keats, ed. Maurice Buxton Forman (Toronto: Oxford University Press, 1935), p. 336.

6.Samuel Taylor Coleridge, Biographia Literaria, or Biographical Skethces of My Literary Life and Opinions, ed. George Watson (London: Everyman's Library, 1987), p. 20.

7.John Locke, An Essay Concerning Human Understanding, ed. Peter Nidditch (Oxford: Clarendon Press, 1988), II, 20, i; emphasis original.

8. Joseph Addison, Richard Steele and Others, The Spectator Vol. III, No. 418, ed. Gregory Smith (New York: Everyman's Library, $1967)$, P. 298 . 
9. Charles Robert Maturin would agree that observed suffe-ing teaches us to value our own position, but he disagrees that such pleasure must be far removed. In Melmoth the Wanderer, one of his villains explains,

It is actually possible to become amateurs in suffering. I have heard of men who have travelled into countries where horrible executions were to be daily witnessed, for the sake of that excitement which the sight of suffering never fails to give, from the spectacle of a tragedy, or an auto da fe, down to the writhings of the meanest reptile on whom you can inflict torture, and feel that torture is the result of your nwn power. It is a species of feeling of which we can never divest ourselves,--a triumph over those whose sufferings have placed them below us, and no wonder,-suffering is always an indication of weakness,--we glory in our impenetrability. (Maturin, Melmoth the Wanderer: A Tale, ed. Alethea Hayter, [Markham, Ont., : Penguin Books, 1984], pp. 284-285.)

10.Walter Benjamin; Il uminations, ed. Hannah Arendt (New York: Schocken Books, 1969), p. 101.

11. Terry Eagleton, The Ideology of the Aesthetic (Oxford: Basil Blackwel1, 1991), p. 13 . 
12.John Beer, Wordsworth and the Human Heart (New York: Columbia University Press, 1978), p. 11.

13. For discussions of this process see Charles Taylor, Sources_of the Self: The Making of the Modern Identity (Cambridge, Mass: Harvard University Press, 1989), p. 331; Michel Foucault, Discipline and Punish: The Birth of the Prison, trans. Alan Sheridan (New York: Vintage Books, 1979); and Pietre Spierenburg, The Spectacle of Suffering: Executions and the Evolution of Repression from a Preindustrial Metropolis to the European Experience (New York: Cambridge University Press, 1984).

14. Contrary to its name, however, the guillotine was not invented by Guillotin. As Dorinda Outram notes, the guillotine was already a popular tool of execution in fifteenth-century Italy, and appears frequently in art from the period. The guillotine sinply became more popular in France because it was more foolproof and less messy than the axe (especially if that axe were in the hands of a reluctant executioner, who might flinch at the last minute). See Outram, The Body and the French Revolution: Sex, Class, and Political Culture (New Haven: Yale University Press, 1989), pp. $106 f f$.

15. Indeed, according to the OED, "guillotine" also became in the late nineteenth-century the name for a surgical tool used to remove the tonsils or the uvula. 
16. Michel Foucault, The Birth of the Clinic: An Archeology of Medical Perception, trans. A.M. Sheridan Smith (New York: Vintage Books, 1975), P. xii.

17.Foucault, $\underline{\text { clinic }}$ and David B. Morris, "The Marquis de Sade and the Discourses of Pain: Literature and Medicine at the Revolution," in The Lanquages of Psyche: Mind and Body in Enlightenment Thought, ed. G.S. Rousseau (Berkeley: University of California Press, 1990), p. 297.

18.Wilbert E. Fordyce, "Learning Processes in Pain," in The Psychology of Pain, ed. Richard A. Sternbach (New York: Raven Books, 1986), p. 49.

19. David B. Morris, The Culture of Pain (Berkeley: University of California Press, 1991), p. 9.

20. See Doreen R.G. Browne, "Ritual and Pain," in The History and Management of Pain from Early Principles to Present Practice, ed. Ronald Mann (Park Ridge, New Jersey: Parthenon Books, 1988), p. 40; H. Merskey, "The Nature of Pain," in Pain: Meaning and Management, ed. W. Lynn Smith et al. (New York: SP Medical and Scientific Books, 1980), P. 71; Richard A. Sternbach, "Clinical Aspects of Pain," in sternbach, Psychology, p. 226; and Morris, culture.

21. Quoted in Elaine Scarry, The Body in Pain: The Making and Unmaking of the World (New York: Oxford University Press, 1985), p. 33 . 
22. Diana Fuss, Essentially Speaking: Feminism, Nature, and Difference (New York: Routledge Publishing, 1989), p. 52.

23.L.J. Rather, Mind and Body in Eighteenth-Century Medicine: A Study Based on Jerome Gaub's "De regimine mentis" (London: William Clowes, 1965), p. 57.

24.R.K. French, Robert whytt, the Soul, and Medicine (London: St. Ann's Press, 2969), p. 152.

25.Robert Whytt, "Observations on the Nature, Causes, and Cure of those Disorders which are Commonly called Nervous, Hypochondriac, or Hysteric," in The Works of Robert Whytt. (Edinburgh: Balfour, Auld, and smellie, 1768), Preface.

26.R.F. Brissenden, virtue in Distress: Studies in the Novel of Sentiment from Richardson to Sade (New York: Barnes and Noble, 1974), P. 42 .

27.John Mullan, Sentiment and. Sociability: The Language of Feeling in the Eighteenth Century (Oxford: Clarendon Press, $1988)$, p. 230 .

28. Dorinda Outram describes this work, carried on by Theolphile de Bordeu, in The Body and the French Revolution, pp. 54-55. 29. Foucault, Birth; and Hermione de Almeida, Romantic Medicine and John Keats (New York: Oxford University Press, 1991), p. 46. 
30.L.J. Jordanova, "Guarding the Bedy Politic: Volney's Catechism of 1793," in 1789: Reading, Writing, Revolution--Proceedings of the Essex Conference on the Sociology of Literature, July 1981 , ed. Francis Barker et al. (Essex: University of Essex Press, 1982), p.16.

31. Brissenden, Virtue, pp. 42-43.

32. Brissenden, virtue., P. 31.

33. Mary Poovey, "Ideology and The Mysteries of Udolpho,"

Criticism 21 (1979): pp. 307-330; and Stephen D. Cox, "The Stranger within Thee": Concepts of the Self in Late EighteenthCentury Literature (Pittsburgh: University of Pittsburgh Press, 1980).

34.Adam Smith, The Theory of Moral Sentiments, ed. D.D. Raphael and A.L. Macfie (Oxford: Clarendon Press, 1976), p. 9.

35.David Marshal1, The Surprising Effects of Sympathy: Marivaux, Diderot, Rousseau, and Mary Shelley. (Chicago: University of Chicago Press, 1988), p. 169.

36. Burke is more suspicious than shaftesbury's school of the propensity of human beings to act disinterestedly. For Burke, human self-interest and aggression must be curbed by society and tradition, which is his chief starting point in Reflections on the Revolution in France. Whereas the Moral school begins with an assumption of benevolent primitivism which assures human 
community and orderly behavious, Burke, like Hobbes, assumes that we act in self-interest, and that our primitive tendencies must be curbed by a social contract.

37. The ability to enter fully into someone else's experience is not only assumed by the Gothic, but it is also feared by it. In Between Men: English Literature and Male Homosocial Desire (New York: Columbia University Press, 1985), Eve Kosofsky Sedgwick locates "homosexual panic" in this ability at the end of the eighteenth century. For her, homosexual panic in novels like Caleb Williams, Private Memoirs and Confessions of a Justified Sinner, and Erankenstein proceeds from the male protagonist's fear that another man is haunting him, that another man is inside him. This invasion of the inside by the other is the bleak Gothic rendition of what was, for Burke, the moral source of community.

38. Gerald Bruns, "Wordsworth at the Limits of Ronantic Hermeneutics," The Centennial Review 33 (1989), pp. 402-403. 39. De Almeida argues that "the Romantic physician and Keats's poet were expected to have a dual consciousness of pain--as a patient and a physician--and healing knowledge, and the comprehending imagination of disease was tied to the actuality and actual experience of pain. As Keats said to his friend Reynolds in May 1818, Until we are sick, we understand not - ." (56-7). De Almeida reads this to mean that when we are sick, we automatically know how other sick people feel. I'm not 
sure that our own illness can guarantee this knowledge. Robert Whyt"'s studies began: precisely because people experienced pain differently and, as I've already noted, there are innumerable studies to suggest the class, gender, and religious differences which intrude into the experience of pain, not to mention the linguistic differences in the expression of that pain. When we are sick, we know how we feel; I'm not sure we can generalize from there.

40. Frances Ferguson, "Malthus, Godwin, Wordsworth, and the spirit of Solitude," in Literature and the Body: Essays on Populations and Persons, ed. Elaine Scarry (Baltimore: Johns Hopkins University Press, 1988), p.106.

41.For Eagleton, Mary Poovey, and C.B. Macpherson, this simultaneous sociality and autonomy is linked to the rise of bourgeois capitalism. It defines what Macpherson calls "possessive individualism", in that it gives one a sense of ownership of one's own body, but ownership that then allows one to sell that body's labour or contribute in other ways to the social marketplace of trade. See The Political Theory of Possessive Individualiss: : pbbes to Locke (Oxford: Oxford University Press, $196: ;$ p. 215.

42. Cesare Beccaria, On Crimes and Punishments (Dei Delitti e delle Pene), trans. Henrr ra-lucci (New York: Bobbs-Merrill Publishers, 1963), p. It 
43. Carl Woodring, Politics in English Romantic Poetry (Cambridge, Mass.: Harvard University Press, 1970), p. 330.

44. Jean-Jacques Rousseau, "On the Social Contract, or Principles of Political Right," in Jean-Jacques Rousseau: Basic Pol itical

Writings, trans. Donald A. Cress (Indianapolis: Hackett Press, 1988), pp. 203-204.

45. Taylor, Sources, p. 370 .

46. See Poovey, "Ideology," p. 316.

47. de Sade, "Philosophy in the Bedroom," in Complete, p. 303.

48.William Wordsworth, The Fourteen-Book Prelude, ed. W.J.B. Owen (Ithaca: Cornell University Press, 1985), IX, 511-520.

49.Ronald Paulson, Representations of Revolution $(1789-1820)$ (New Haven: Yale University Press, 1983), p. 42.

50.For a description of this, see Edmund Burke, Reflections on the Revolution in France (Markham, Ont.: Penguin Books, 1986), p. 164 .

51.On the dual meaning of "revolution" and its significance for the end of the eighteenth century, see Paulson, Representations, pp. $49-50$.

52. Janet Todd, Sensibility: An Introduction (New York: Methurn Publishing, 1986), p. 130 . 
53. William Wordsworth, "A Letter to the Bishop of Llandaff on the Extraordinary Avowal of his Political Principles Contained in the Appendix to his late Sermon by a Republican," in The Prose Works of William Wordsworth Vol. I, ed. W.J.B. Owen and Jane Worthington Smyser (Oxford: Clarendon Press, 1974), 2:52-62.

54. William Godwin, An Enquiry Concerning.Political Justice (Markham, Ont.: Penguin Books, 1976), p. 635.

55. Thomas Paine, The Rights of Man (Markham, Ont.: Penguin Books, 1984), pp. 49-50.

56. In fact, for Immanuel Kant, reliance on the ojjecs world obfuscated one's moral alignments as well--that is, the grounding of moral conduct totally within the self, without reference to Nature or political ideology to authenticate behaviour. See Taylor, Sources of the SelE, p. 363.

57. Quoted in Outram, p. 9.

58. Prelude $x, 379-80$.

This same classicism that Outram sees ill Jacques Louis David, I would suggest, underlies the depiction of a number of Gothic villajins who, in Paulson's analysis, represent the French revolutionary and who are condemned by their conservative authors for their passions. Ambrosio in Lewis's The Monk, Montoni and Schedoni in Radcliffe's The Mysteries of Udo) ? and The Italian respectively, and even that much laker but equally potent threat to British purity, Count Dracula, all share the dubious honour of 
a classical physical description--with aquiline nose, mysterious visage, dark complexion, cool, reserved but stately demeanour, and so forth. And what makes their descriptions even more interesting in regard to Norbert's notion of the homo clausus is their consciousness of the people who are watching them, and the way they respond to being watched. Both Ambrosio and Schedon,, for example, refuse to allow their spectators' gaze to penetrate into their being: they constantly force the onlooker to behold the surface, and the surface only.

59.M.H. Abrams, Natural Supernaturalism: Tradition and Revolution in Romantic Literature. (New York: Norton Publishing, 1971), p. 215.

60. Rene wellek describes European Romanticism as "a revival of Neoplatonism, a pantheism (whatever its concessions to orthodoxy), a monism which arrived at identification of God and the world, soul and body, subject and object." See "The Concept of 'Romanticism' in Literary History," Comparative Literature 1 (1949): pp. 147-172. This quotation appears on p. 150 .

61. [Henry] john [Franklin] Jones, The Egotistica] Sublime: A I!istory of Wordsworth's Imagination (London: Chatto ard windus, 1954), pp. 6-7.

62. James Averill, wordsworth and the Poetry of Human suffering (Ithaca: Cornell University Press, 1980), p. 30; A.D. Nuttal makes a similar point about wordsworth and Hume in A Common sky: Philosophy and the Lite:ary Imagination (Berkeley: University of 
California Press, 1974), p. 136.

63. See Michael Fried, Absorption and Theatricality: Painting and Beholder in the Are of Diderot (Berkeley: Universit? of California Press, 1980); and John Bender, Imagining the Penitentiary: Fiction and the Architecture of Mind in EighteenthCentury England (Chicago: University of Chicago Press, 1987).

64.William Patrick Day, In the Circles of Fear and Desire: A Study of Gothic Fantasy (Chicago: University of Chicago Press, $1985)$.

65. I am borrowing the title of Helen Neal's 1978 book The Politics of Pain (New York: McGraw-Hill Publishing, 1978). In this work, Neal discussed the various ways in which political considerations determine the pain treatment ore receives. 66. For an excellent study on Kea'; and pain, see de Almeida, Romantic Medicine and John Keats. 
Chapter Two: Imagining Pain

\begin{abstract}
I
We had not travelled long ere some mischance Disjoined me from my Comrade, and, through fear Dismounting, down the rough and stcny Moor I led my horse, and, stumbling on, at length Came to a bottom, where in former times A murderer had been hung in iron chains. The Gibbet mast had mouldered down, the bones And iron cage were gone, but on the turf Hard by, soon after that fell deed was wrought, Some unknown hand had carved the Murderer's name.l
\end{abstract}

This spot seemed the very haunt of banditti, and Emily, as she looked down upon it, almost expected to see them stealing out from some hollow cave to look for their prey. Soon after an object not less terrific struck her,--a gibbet standing on a point of rock near the entrance of the pass, and immediately over one of the crosses she had before observed. These were hieroglyphics that told a plain and dreadful story.2

In 1793 Wordsworth travelled across Salisbury Plain, where he had the experience that would provide the "spot of time" for the section of The prelude quoted above. ${ }^{3}$ The same year, Ann 
Radcliffe published not her first, but certainly her most popular and critically successful novel, The Mysteries of Udolpho. With their contemporary history comes a shared mode of expression: Radcliffe is, of course, the "mother" of the English Gothic - avel, and debatably its most famous practitioner; Wordsworth began his career in the Gothic mode with poems like The vale of Esthewaite and the unfinished "Gothic Tale," which are conventionally sensational in tone and subject matter. Indeed, The vale of Esthewaite sounds like a Radcliffe novel in verse.1 Moreover, the scenes quoted above depict a common subject matter: they both depict a spectator who comes upon a place which has been the site of someone's intense physical pain, and they record the spectator's reaction to that place. Finally, both descriptions are produced during a time when England is preoccupied with a sensational and graphic site of suffering: the 1793 Reign of Terror in France. I propose here to read these contemporaries together to see how Radcliffe and the young Wordsworth handle their gothic framework, a framework which incorporates physical pain as it is imagined by the spectator, and to speculate on what the political implications of that treatment might be.

Wordsworth's original depiction of the gibbet experience in his 1793-94 A Night on Salisbury Plain undergoes radical revisiun before becoming a boyhood memory in the prelude. In the early version of salisbury Plain, the traveller finds an existing gibbet wherein "In clanking chains a human body hang [and]/ A 
hovering raven oft did round it fly" (115-116). In the second version of the poem, Adventures on Salisbury plain, the traveller is a murderer, and so the gibbet symbolizes a direct physical threat to him. The boy of The Prelude, on the other hand, sees only "monumental Letters . . inscribed/ In times long past" (XII, 241-242); thi landscape poses no real danger for him.s And it poses even less danger for the adult poet looking back on this childhood incident. Similarly, Emily reads the "plain and dreadful story" of the gibbet as posing the threat of murderous banditti who imprison their victims, yet this story's status as "hieroglyphics" helps to distance it in the past, to make it less personally threatening, despite the terror it inspires. In fact, even though Emily associates the gibbet with great personal danger--she expects to see banditti steal out and attack her--the danger is, like most others in Udolpho, greatly exaggerated by the excesses of the imagination and, in the end, poses no real personal threat.6 Emily and her caravan reach their destination of Rousillon with hardships no greater than tired mules and windblown clothing.

Both Radcliffe's depiction of Emily's terror and Wordsworth's softening of the gibbet's punitive implications reduce a "dreadful story" of past physical suffering to a benign scene of reading. In so doing, the authors betray their mutual suspicion of the mode in which they are writing: both writers advocate restraint in the way such a scene as the gibbet should be looked at. Wordsworth's early descriptions border on the 
"application of gross and violent stimulants" which are the property of those "frantic novels, sickly and stupid German Tragedies, and deluges of idle and extravagant siories"7 that the older Wordsworth so intensely disliked, and which the later Prelude tries to tame. Similarly, Ann Radcliffe was suspicious of the potentially excessive passions of contemporary literature. The best-known spokesperson for this suspicion is Emily st. Aubert's father who, as he lies on his death bed, warns against the excesses of the literature of Sensibility (the novelistic mode in which, paradoxically, his character appears). He tells Emily,

Abnve all,. . do not indulge in the pride of fine feeling, the romantic error of amiable minds. Those who really possess sensibility, ought early to be taught, that it is a dangerous quality, which is continually extracting the excess of misery, or delight, from every surrounding circumstance. And, since, in our passage through this world, painful circumstances occur more frequently than pleasing ones, and since our sense of evil is, I fear, more acute than our sense of good, we become the victims of our feelings, unless we can in some degree command them.

While there may be important differences here between the German sturm und Drang, which Wordsworth condemns, and the novel of Sensibility, which is Radcliffe's subject, the warnings are the 
same: literature seeks to move us through intense stimulation, but that stimulation can be dangerously excessive. It can make us slaves of our own imaginings.

A common interest of Wordsworth and Radcliffe, then, is in how the ingenuous spectator imagines a scene of physical suffering. This shared interest comes out of a developing fascination with the aesthetics of physical pain in the late eighteenth century. As I discussed in the previous chapter, the relationship between imagination and pain came under the dissecting knife of philosophical speculation in the latter half of the century. The increased fascination with pain brought with it speculation on the role of pain as it relates to pleasure, and with how Locke's pain/pleasure structure constitutes both the aesthetic and the social being. Given this interest, I want to discuss the scenes of imagining pain in Wordsworth and Radcliffe as the moments in which the authors face a difficult but potentially fruitful task. The Gothic convention of imagining pain, I hope to show, is what gives the Gothic hero his/her place in a social community. However, the degree to which one imagines pain in the Gothic is the degree to which one finds that pain unimaginable and, therefore, the act of imagining pain is what isolates him/her from any possiblitty of community.

The most famous theoretician of imaginatzon and pain in the eighteenth century, and the one to whom wordsworth and Radcliffe are most indebted, is Edmund Burke. In Burke we find one of the must sustained discussions of the relationship between 
imagination, pain, and society. In chapter one, I discussed how, according to David Marshall, imaginative sympathy in Marivaux and Smith was a construction that always suggested its own artificiality and limitation. One could never know how another person felt. In Burke's Enquiry into.... the sublime and Beautiful, however, pain could be a potential source for community, in that the observer put himself in the place of the actual sufferer of pain. This substitution is itself an act of imagination, but without the seeming boundaries imposed by consciousness; in Burke, the subject's body is imaginatively interchangeable with the victim's body. In fact, imagined pain-what Burke calls "fear" or "terror"--behaves in exactly the same way as "real" or experienced pain. To illustrate this point, Burke imagines "a man in great pain [who] has his teeth set, his eyebrows are violently contracted, his forehead is wrinkled" and so on. For the observer looking on,

[f]ear or terror, which is an apprehension of pain or death, exhibits exactly the same effects, approaching in violence to those just mentioned in proportion to the nearness of the cause, and the weakness of the subject. . . The only difference between pain and terror, is, that things which cause pain operate on the mind, by the intervention of the body; whereas things that cause terror generally affect the bodily organs by the operation of the mind suggesting the danger; . . they agree likewise in everything else. (p. 131) 
In the experience of terror, the mind imagines a certain physical experience which it then reproduces on the body as the experience of pain. It then transmits that pain to the part of the anatomy where it was located in the observed object experiencing pain. In other words, we feel the "wound" in our limbs or organs through a kind of sympathetic identification, one produced by the imagination. In Burke, the direction of the sentient process (mind to body, body to mind) is what distinguishes physical from imagined pain, but the ultimate effect in the mind is the same. The body becomes a communally shared property. 9

However, Burke is emphatic that pain can never be a pleasure, only a delight, by which he means that observed pain can only be pleasurable because it is characterised by distance, by the fact that the pain is not the observer's. Pain and danger are delightful--and possibly sublime--only to the degree that they are removed from one's immediate experience. Absolute physical pain, says Burke, is "always odious" (p. 37), and the affliction we suffer as observers "has no resemblance" to it. If pain "press[es] too nearly" (p. 40) or "too close" (p. 46), it freezes the sensibilities and closes us off from any feeling whatsoever. We think only of ourselves and our selfpreservation. (This phenomenon, as I shall discuss, Radcliffe calls "horror," as opposed to "terror.") Thus, while pain is identical to that which can be imagined, the imagination depends upon the spectator not really coming into contact with physical pain. It would seem that Burke is basing his discussion of 
imagination and pain on a conizadiction in the observing or imagining spectator. On the one hand, we feel and are capable of imagining another's pain so tha'c that pain (which, in the victim, is unquestioningly present) behaves in the same way as the observer's pain (which, by definition, is absent or distanced). But when we do feel that pain, when we substitute ourselves for the victim and mentally make the pain our owr, we close ourselves off and protect our interests. Burke lauds the power of the imagination to create the experience of pain, yet he does not follow through on the implications of what imagined pain might mean for the observing subject who then feels that pain.

As I had noted in chapter one, Burke is trying to negotiate a complex terrain of privacy and publicity in the Enquiry. For Burke, the imagination makes us public beings, and the potential for public interconnection is all the more present when we imagine ourselves into another's pained body. However, this body, which opens up the possibility of community, also threatens to foreclose upon community. If the imagination allows us to substitute ourselves for another, then it risks that odious experience of pain, the experience which forces us to close in upon ourselves and destroys the very community it claimed to construct. Thus, Burke's imagined pain must be carefully regulated: it must exhibit "exactly the same effects" as real pain, yet bear no resemblance to it. In order to constitute the social fabric, the imagination of pain must have limits imposed. To understand more fully the social and political 
implications of those limits, I want to turn to Elaine Scarry's The Body in Pain as a framework to discuss imagination and pain in the Gothic. In one way, Scarry re-inscribes the distinctive incompatibility of imagination and pain--of mind and body--that philosophers of Sensibility like Burke were attempting to destroy. In her analysis, pain is differentiated from any other state of consciousness because, she says, it is totally interior in its referentiality. To explain:

Contemporary philosophers have habituated us to the recognition that our interior states of consciousness ¿ro regularly accompanied by objects in the external world, that we do not simply "have feelings" but have feelings for somebody or something, that love is love of $\underline{x}$, fear is fear of $y$, ambivalence is ambivalence about ?. (p. 5)

But the experience which is least likely to have an external referent is pain, because pain needs no object to give it meaning;

physical pain--unlike any other state of consciousness --has no referential content. It is not of or for anything. It is precisely because pain takes no object that it, more thain any other phenomenon, resists objectification in language. (p. 5)

Thus, in pain we are usually incapable of imagining anything other than our own bodies. Pain eradicates the external world and proclaims the primacy and irreducibility of hurting. 
sut if pain foregrounds the body's imnediacy, then the imagination depends upon the body's distance, and upon the body's making no demands upon the imagination, demands which might distract it from its functioning as imagination.

The only state that is as anomalous as pain is the imagination. While pain is a state remarkable for being wholly without objects, the imagination is remarkable for being the only state that is wholly its objects. There is in imagining no activity, no "state," no experienceable condition or felt occurrence separate from its objects: the only evidence that one is "imagining" is that imaginary objects appear in the mind. (p. 162)

From this lack of external referent, scarry reasons that all imagined materialities are by definition immaterialities. The imagination "may well provide an object for other forms of sentience, an imaginary object of hearing. . . or an imaginary act of touch. . . but the object it provides is never provided for any experienceable form of sentience unique to itseif" ( $p$. $162)$.

In Scarry's discussion, pain and the imagination are the "extreme conditions" of our consciousness; when we are in pain, we are aware of nothing but the existence of our bodies, and when we imagine, we are aware of anyli:ing but the body, whatever: external objeit uccupies the imagination at a given moment (even if that object is an imaginative reconstruction of the body 
itself). Pain and imagination become for scarry the "framing events' within whose boundaries all other perceptual, somatic, and emotional events occur; thus, between the two extremes can be mapped the whole terrain of the human psyche" (p. 165). At one level, these extremes appear to recapitulate a rather discomforting Cartesian dualism in which all experience rests on a battlefield between res cogitans (here, the imagination) and res extensa (the body in pain). Moreover, it explains the problem of sympathy which David Marshall located in Marivaux: if one cannot imagine one's own pain, then one is certainly in no position to imagine someone else's. But scarry's framework stresses the istermediary status of imagination and pain as a complex negotiation between the t:vo extremes. In her scheme, the imagination and pain are mutually constitutive, in that the imagination always responds to some perceived lack in bodily necessity: we imagine things in order to imagine airay some physical limitation or disturbance. Yet significantiy, we imagine precisely to increase our physical sentience, our feeling of being in the world. Thus, imagination is "aesthetic" in the two senses I described earlier: it is both embodied and disembodied in a way that is reminiscent of Edmund Burke. Society as it is defined by Burke is a tapestry of attempts to imagine someone else's physical sentience, and to imagine ourselves outside of our own skins in order to do so. Yet, the attempt is always overshadowed by a regulator within itself: imagination must always remain at some disiance from pain if it 
is not to be destroyed by it. Imagination and pain are mutually dependent, but the mechanics of this dependence become all the more tenuous when we recognize that these framing extremes can be potentially mutually exclusive when the threshold of pain becomes too great. Pain can both interact with the imagination and destroy it.

\section{I I}

The distinction between the imagination and pain is significantly similar in structure to Ann Radcliffe's distinction between terror and horror. This now famous definition originally appeared in the New Monthly Magazine (vol. 7, 1826) in a dialogue essay called "On the Supernatural in Poetry." Here Radcliffe, through the character of Mr. W---, explains:

They must be men of very cold imaginations with whom certainty is more terrible than surmise. Terror and horror are so far opposite, that the iurst expands the soul, and awakens the faculties to a high degree of life; the other contracts and freezes, and nearly annihilates theni. I apprehend that neither shakespeare nor Milton by tisir fictions, nor Mr. Burke by his reasoning, anywhere looked to positive horror as a source of the sublime, though they all agree that terror is a very high one; and where lies the great difference between terror and horror, but in uncertainty and obscurity, that accompany the first, respecting the dreader evil? 10 
In the first part of this passage, terror is that Burkean quality of experience that can lead to the sublime. It "expands the soul, and awakens the faculties to a higher degree of life," an awakening which for Burke was characteristic of the passions which lead to society. Such is Emily's experience in The Mysteries of udolpho; for her, "a terror of this nature, as it occupies and expands the mind, and elevates it to high expectation, is purely sublime, and leads us, by a kind of fascination, to seek even the object, from which we appear to shrink" (p. 248). Terror, then, is that carefully regulated aesthetic experience that can use intense feeling to seek objects in the world, objects which can include people in distress. Conversely, horror "contracts, freezes, and nearly annihilates" the passions which lead to community, and forces the horrified spectator to enclose and protect the self. Horror behaves for Radcliffe in the same way that absolute pain behaves for Burke: both render us antisocial and self-protecting. For Radeliffe, then, the distinction between terror and horror is analogous to the larger distinction between society and solitude. Terror situates us in the social world, the world of the outside, while horror freezes us within the self.

Significantly, Radcliffe's distinction between terror and horror is also a distinction between imagined and corporeal sentience. "Terror," the OED tells us, comes from the Latin terrere, meaning "to frighten." As a distinctly emotional condition, it is "the state of being terrified or greatly 
frightened; [of being in] intense fear, fright, or dread." In scarry's terminology, it is the imaginal, emotional condition of fearing an object in the external world, or of the danger it potentially provides. The tentativeness of this fear, its particularly imaginative status, is what Matthew Lewis found so disappointing about Radcliffe's novel; for him, she refused to take her sensations far enough.11 There was in a Radcliffe novel no real pain, nothing graphic, nothing of the horrible. Horror is particularly physical. It proceeds from the latin horrere, meaning "to bristle or shudder." And in its attendant definitions, it usually zefers to things corporeal: "roughness or nauseousness of taste such as to cause a shudder or thrill; a shuddering or shivering, now especially Medical as a symptom of a disease; a painful emotion compounded of loathing or fear" (OED). Whereas the socializing agency of terror, by the OED's definition, relies upon imaginative stimulation, the selfpreserving agency of horror appeals to and exploits the sentient body. Not content with the imaginative state of terror, horror seeks to invoke the corporeal state of pain.

Radcliffe incorporates this distinction into her novels by contrasting the effects of terror and horror on h:r heroines. These heroines often imagine someone else's pain in scenes which demonstrate their great selflessness and concern for others. In the 1791 novel The Romance of the Forest, Adeline de st. Pierre is being held captive by her rakish, villainous suitor, the Marquis de Montilt. As she pines for her lover and potential 
liberator Theodore, whom the Marquis has wounded and imprisoned, Adeline iecomes sensitive to the fact that Theodore has sustained his wounds wille defending her:

That the very exertions which had deserved all her gratitude, and awakened all her tenderness, should be the cause of his destruction, was a circumstance so much beyond the ordinary bounds of mercy, that her fcrtitude sunk at once before it. The idea of Theodore suffering--Theodore dying--was for ever present to her imagination, and frequently excluding the sense of hel own danger, made her conscious only of his.12

As Burke had described it, imagined pain here effects an enptying out of self that allows the imaginer to exchange places with the sufferer, and to be totally taken up with the plight of another. Indeed, it is what constitutes moral virtue in the novel. In The Mysteries of jdolpho, the heroine takes her fear of the wounded body to its extreme, to a fear of murder. Emily is so preoccupied with "the image of her aunt murdered" that she gives up all thoughts of self and self-preservation to search out Udolpho's turrets until she finds her (p. 323). This search is not undertaken without a great deal of trepidation, but Emily is so overpowered by the "groans of [a] wounded person" ( $p .318$ ) and a trail of blood ( $p$. 323) that she takes the risk numerous times. Like all Radcliffe's heroines, Adeline and Emily are motivated by the "horrid spectacles" (Udolpho, 323) which replace their own endangered bodies and become the centres of their conscious 
activities. But I want to stress the significance of the fact that those spectacles--those wounded, dying, or dead bodies--are imagined; their pain is always distanced by image, by fear, and by hypothesis. These painful bodies are emphasized as imaginative constructions.

If these communal moments of selflessness distance the suffering or dead body, they are not the only moments in a Radcliffe novel to do so: much of a Radcliffe plot centres on the imaginative invocation of a mutilated body which nover then seems to materialize. The Romance of the Forest, for example, has at the centre of its plot the discovery of a manuscript which recounts torture and pain. Adeline has had a series of dreams in which she first sees a man "convulsed in the agonies of death" (p. 108). In a later dream, she sees the same figure dead, and with blood gushing from his side (p. 109). When she awakes, she discovers in the abbey a room exactly like that where her dream had represented the dying person; the remembrance struck so forcibly upen her imagination, that she was in danger of fainting; and looking round the room, almost expected to see the phantom of her dream. (p. 115)

What she finds, however, is not a convulsed and wounded body, but rather a manuscript written many years ago. The characters of this manuscript are often obliterated, as is the character who wrote it: he writes, "your pity now is useless: long sinc, have the pangs of memory ceased; the voice of complaining is passed 
away" (p. 128). But while the pangs may long have ceasec', Adeline, like all devoted readers of the Gothic, cannot put tine manuscript down for long. It "awakened a dreadful interest in the fate of the writer, and called up terrific images to her mind" (p. 128). The "wretched writer appealed directly to her heart; $t=$ spoke in the energy of truth, and, by a strong illusion of fancy, it seemed as if his past sufferings were at this moment present" (p. 132). These sufferings, made to seem real by the force of Adeline's fancy, are of course never present; the wounded, afflicted body is always only imagined. And those sufferings become all the more poignant when Adeline discovers that the author is her dead father, killed by his brother the Marquis de Montalt. The father's pained body here becomes the medium for an "anguish and herror of her mind [which] defied all control" (p. 347), but this body is also mere imagination, record, memory (pp. 346-347), whose immediacy the novel avoids. Similarly, The Mysteries of Udolpho both invokes and avoids the immediate suffering of the mutilated body. As Emily searches for her aunt, in the scene I discussed earlier, she finds a heap of bloody clothes in a room. Assuming them to be her aunt, she instead uncovers " 3 heap of pikes and other arms" (p. 323). Likewise, the body behind the veil, "the human figure of ghastly paleness, stretched at its length, and dressed in the habilements of the grave... . the face [that] appeared partly decayed and disfigured by worms, which were visible on the features and hands" ( $p .662$ ), is a wax representation and not a mutilated 
human body at all. This representation, furthermore, Emily assumes to be the body of the "late" Laurentini, whose story Emily's father has forbidden her to hear. But instead, it is yet another swerve away from the presentation or mutilation, as it is a momento mori, an agent of instruction. Finally, we remember Vivaldi, the hero of The Italian, who is abducted by the Inquisition and is about to be put to the question, that is, he is about to be tortured. As he is led out of the room, the narrative focus switches to Ellena, his beloved, and we are forced to wait for almost 100 pages before we find out whether Vivaldi is wracked in pain from torture!13 Repeatedly, Radcliffe's novels invoke physical mutilation, suffering, and even death to stimulate great emotional activity, but to emphasize that this emotion is imaginatively generated. For all the Gothic terror, there is very little Gothic horror.

These imaginative constructions in the absence of real pain represent the heroine's ability--or inability--to deal with pain in others when it does finally occur. When Theodore first received the wounds which Adeline reconstructs in memory, her frightened sensibilities made her sympathy for him tenuous and liminal. At the original scene of battle,

The blood gushed from the wound; Theodore, staggering to a chair, sunk into it, just as the remainder of the party entered the room, and Adeline [who, conveniently, "had fainted almost at the beginning of the dispute"] unclosed her eyes to see him covered with blood. She 
uttered an involuntary scream, and exclaiming, 'they have murdered him', nearly relapsed. (p. 176)

Adeline looks for wounded bodies, but faints when she finds them. In fact, while the ability to imagine and to sympathize with pain constitutes virtue in the novel, Adeline rather consistently swoons in the face of real wounds and real groans. When she hears Theodore in another fight over her honour, she is roused to action by "the image of Theodore, dying at the hands of the Marquis," and she makes "a desperate effnrt to force open the door, and again [call] for help." significantly, it is the image here which invigorates Adeline and forces her to act. But when she hears the "loud shriek" and "deep groans" of actual physical wounding, the "confirmation of her fears [deprives] her of all her remaining spirits, and growing faint, she [sinks] almost lifeless into a chair near the door" (p. 196). In the Gothic, sinking into a chair signifies overwhelming physical agitation; as Burke had said, the observer's body mimics the sufferer's, as here Adeline collapses like the wounded, bleeding Theodore. But it does not. suggest, as Burke would have it, that the experiences of imagined and fleshly pain are the same thing. Even in Adeline's dreams--moments of pure imagination without material correlative--she entertains visions of Theodore in distress, "convulsed in agonies of death" (p. 108) or "in chains, struggling with the grasp of ruffians" (p. 259). But the visions terminate the moment they become too physical, the moment, in Burke's phrase, they "press too nearly." In the dream which I 
noted above, the conjured victim "suddenly stretched forth his hand and, seizing her's, grasped it with violence: she struggled in terror to disengage herself. . [and] the effort she made to save herself. . awoke her" (p. 108). In a later dream, she "saw him led, amidst the dreadful preparations for execution, into the field: she saw the agony of his look and heard him repeat her name in frantic accents, till the horrors of the scene overcame her, and she awoke" (p. 259). At precisely the moment in which imagined pain threatens to become physical--when it is about to assume its status as "horror"--the imagination halts its own projective capabilities. When consciousness comes face to face with its object, it freezes. The socializing force which constitutes the construction of community--the force which R.F. Brissenden calls "virtlue in distress"14--is halted at the moment of the perceiving sibject's threatened violation and danger. But more to the point, that perceived threat lies at the threshold of the sentient, corporeal body.

That the sentient body should refuse the sentience it sympathetically wants to feel is only logical, since the body is moving from a state of imagined pain into one of "horror," in which "real" pain is inscribed upon the body by its claims to imaginative projection. This claim--and its limitations-fascinate Radcliffe. Again in The Myster-es of Udolpho, sine delineates the subtle aesthetics of imagined pain. In the following vignette, Emily is exploring the castle for some clue 
as to what has happened to her abducted aunt. As she searches a distant turret, she comes upon a curious room in which

she perceived no furniture, except, indeed, an iron ring, fastened in the center of the chamber, immediately over which, depending on a chain from the ceiling, hung an iron ring. Having gazed upon these, for some time, with wonder and horror, she next observed iron bars below, made for the purpose of confining the feet, and on the arms of the chair were rings of the same metal is she continued to survey them, she concluded, trey were instruments of torture, and it struck her, that some poor wretch had once been fastened in this chair, and had there been starved to death. She was chilled by the thought; but what was her agony, when, in the next moment, it occurred to her, that her aunt might have been one of these victims, and that she herself might be the next! An acute pain seized her head, she was scarcely able to hold the lamp, and, looking around for support, was seating herself, unconsciously, in the iron chair itself; but suddenly perceiving where she was, she started from 2 t in horror, and sprung towards a remote end of the room. (p. 348)

Up to a point, this episode echoes Burke: first, Emily gazes in wonder; this gaze produces pity for "some poor wretch" whose body was condemned to the horrors of torture; this imagined attack on 
the body induces its own agony as Emily, the next potential victim, responds in identification and substitution, to the point of placing herself in the chair in which the victim died.ls At this point Emily is the virtuous moral heroine whose experience with the imagined victim replays the contemporary cliche, "I know how you feel." But when the "chilling" thougints of pain become "agony" and "acute pain," she not only loses her ability to imagine another person, but actually is forced to flee to a safe distance and to protect herself. To know how one feels is to feel it oneself, to allow pain into the body, to have it press too close. And imagined pain, once inscribed $n$ the imaginer's body, is horror, which cuts off the community it sought to create. Sympathy, the imagining of another's pain, claims here to be a kind of disempowerment where the subject feels the same physical intensities as the victim--hence, the weakenings, the swoonings, the falling into chairs. But in so doing, this imagination severs the subject/object relationship which effected the weakening and actually empowers the perceiving subject; it escorts her to a remote side of the room.

The kind of empowerment I am describing here has implications for the construction of society. In Radcliffe, the evil threats to the social order-Montalt, Montoni, Schedoni--are always defined by selfishness, by acting completely within their own self-interest to further their economic stature and power. The heroes and heroines, conversely, are selfless and generous: at the level of their sensitive bodies, they respond to others in 
the social community. But it is at the moment of physical sentience that the body's communal possibilities are destroyed. Near the end of Romance of the Forest, disempowering sensibility actually keeps the heroine outside the scene of distress. Adeline has pianned to visit Theodore in prison, but her melancholy imagination represented Theodore at the place of execution, pale and convulsed in death; she again turned her lingering eyes upon him; but fancy affected her sense, for she thought as she now gazed that his countenance changed, and assumed a ghastly hue. All her resolution vanished, and such was the anguish of her heart, that she resolved to defer her jourrey till the morrow... . (p. 336)

Sensibility, as it works itself out in the Radcliffe novel, is a physical weakening to the point of disempowerment: her sensitive characters, especially her women, are included in a coinunity in which all sensitive characters are victims, subject to the perfidies of the villains. But that disempowerment contains the seeds of its own self-protection; Adeline's hypersensitivity here works to keep her away from the scene of hyperstimulation. Similarly, Emily's sensitive soul responds to the bodies of other women, such as Madame Montoni, Laurentini, and the Marchioness de villeroi. But while the novel moves toward identification among these women--indeed, at one point Emily even dresses and looks like the Marchioness--this sensitivity can only go so far. All of these women die horribly, and so Emily must disassociate 
herself from them in order to protect herself from sharing their fate. Extreme sensitivity to another's body in pain exaggerates the heroine's reaction to such a degree that she isolates herself in a swoon, an escape, a self-preservation. The fainting spells are ofter defense mechanisms to keep from feeling too acutely an unpleasant experience. Adeline's and Emily's "individuality" is the logical end of their sensitivity, enclosing their ostensibly socialized bodies within their own private spaces.

Thus we see in Radcliffe's novels a certain ideological configuration that is, in the end, political. When the imaginer of pain imagines herself into a community of others, she isolates herself by finding that imagined community impossible to sustain. In other words, she plays both sides of the solitude/society binarism that the eighteenth century was trying to negotiate. For April Londen, this imagination/isolation structure is essential to the novel's definition of identity. In her materialist reading of The Mysteries of Udolpho, London argues that the imagination in Radcliffe is limitless--indeed, Emily's father was making much the same point in the warning already quoted--and so acts of human will and self-assertion are the only ways to mark the boundaries of a self that otherwise risks being diffused by a free-floating imagination.16 For London, the villainous selfishness of Montoni becomes a model for defining self-presence, one which the other characters must to some degree adopt. While I agree that the novel is intent on marking the boundaries of the self, I disagree that the imagination is 
responsible for the erosion of those boundaries; the imagination in these novels is not limitless. In Radcliffe, as in Burke, the imagination is bounded by the limitations of the sentient body. The moment it projects itself into pain, it finds itself incompatible with the pain being imagined. Thus, while I disagree with London's premise, I agree with her conclusion, one she shares with Mary Poovey, 17 that Radcliffe's novels are ultimately about the empowerment of the individual in a bourgeois sense. But whereas London and Poovey locate that empowerment in the maintenance of private property (ie. Adeline inherits Montalt's estate; Emily returns to her beloved ia Vallee), I would suggest that it is affirmed at a more basic site, the one at which Locke originally located it: in the protagonist's body.18 "For property in the bourgeois sense," writes C.B.

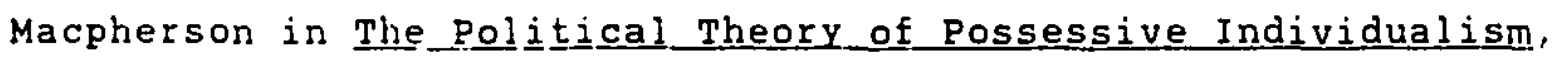
"is not only a right to enjoy or use; it is a right to dispose of, to exchange, to alienate" (p. 215). The body in Radcliffe is property in the sense that it is private in its sentience and public to the degree that it exchanges its sentience with that of another. It reconciles the citizen with the possessive individual.

If maintaining the privacy of the sentient body exists concurrently with the maintaining of private property at the heart of Radcliffe's novels, then Radcliffe's critique of sensibility takes on a particularly material tone. The material threat to both body and property in the novel has been the 
subject of feminist criticism (as I have just indicated), yet it has been lost to those critics who see the novel as satiric. I noted above the critical commonplace that these novels do not go anywhere. Nelson C. Smith, writing on The Mysteries of Udolpho, says that "nothing very terrifying really happens. All that happens, indeed, results from Emily's being a high-strung heroine susceptible to the dangers of sensibility."lg Nothing terrifying happens if we are willing to discount violence, murder, wifebattering, and attempted rape as terrifying. And in a way, they are not terrifying: rather, they occupy the category of the horrible, in which physical pain signifies more strongly than any possible imaginative mitigation of it (mitigation which would consign it to the category of "terror"), and more strongly than the excessive imagination which Radcliffe is satirizing. This satire, I believe, is not only the satire of error that arises from feeling strongly. Rather, Radcliffe admonishes in her heroines the tendency to imagine oneself into states of unconsciousness--into states of horror--when there are real threats circling about them. The object of her lesson is the sensibility which weakens Emily st. Aubert as she flees from the potential rape of Count Morano, or as she faints at the feet of Bernardine, who may have murdered her aunt. It is the sensibility of Adeline st. Pierre as she faints from fear of her oppressors at the beginning of Romance of the Forest, and thus puts herself totally at their mercy. In other words, Radcliffe attacks the sensibility which imagines immediate pain but in so 
doing, makes the imaginer more vulnerable to the violent aggression which might cause that pain.20 she attacks the imagination that uses pain to destroy its connection to the outside world, a world of greed, danger, and oppressive villainy. For it is this imagination, through its fascination with pain and its inability to sustain that fascination, which ultimately puts at risk the real private property: the corporeality of the body. Radcliffe's validation of the body as private property is political in a cultural sense, but it carries overtones of partisan politics as well. At the heart of a Radcliffe novel is the contest between noble, virtuous human nature and material self-interest; between ordered stability and rapid change; between the protected security of the private estate and the usurpation of that estate by pretenders to new wealth. The terms of this contest as I have just laid them out are the same terms that Burke used in 1791 (three years before udolpho) to figure the revolution in France and its effect on England. For Burke, the revolution was a gross attempt to re-empower the middle class at the expense of aristocratic tradition and landed property. It was a demonstration of how personal greed could overwhelm a country's respect for property and propriety, and for the legitimate transfer of wealth. In Ann Radcliffe's novels, the sensitive body replays that antijacobin, Tory position. The sensitive body is made vulnerable to the violence and power of the selfish pretenders, yet it ultimately returns to its protected, secluded estate, isolated irom the outside world's 
tribulation. Moreover, the body transcends self-interest by imaginatively entering into the physical concerns of others, by becoming part of the whole; the body, in other words, becomes part of the republic. Yet, the very potency of its sensitivity keeps it from becoming too fully associated with that whole, too fully a republican. Like the Tory on-looker, the Radcliffe heroine both demonstrates human virtue and isolates that vulnerable virtue from a fallen revolutionary world.

IV

If Ann Radcliffe is the mother of the English Gothic novel (a title she got from Keats), then wordsworth is surely one of its children. As I mentioned earlier, Wordsworth's career began in experimentations with the Gothic--as well as with landscape models provided by Drayton and Milton--and exemplifies many Gothic conventions and images. Among the clearest examples of this influence are the "Fragment of a "Gothic Tale"" (c.1791) and The Borderess (1795-6). According to Paul Sheats, the Gothic was an essential step in Wordsworth's developing conviction that poetry had to indulge the irrational, and that reason and truth were not its sole province.21 However, in this early praise of irrationality there is also another Gothic fixation: the focus on the suffering body. Enid Welsford notes that the beginnings of the Salisbury Plain poems can be located in Wordsworth's childhood fascination with the gibbet, and in the circulating stories of a murderous sailor.22 This interest in the pained body goes beyond mere sensationalism: Sheats argues that it is a 
crucial aspect of a period in Wordsworth's life when he temporarily abandons his interest in transcendental Nature in preference for "ordinariness," for the flesh and blood concerns of the Lyrical Ballads (pp. 40-41). Moreover, Sheats says that a poem like Salijbury Plain marks a momentary suppression of his meditations on the self, and treats the object as object, and not as "something far more deeply interfused" with his own imagination.23 But the concern with pained bodies, we must remember, is a temporary concern. Wordsworth is moving toward the presentation of a "Sorrow that is not sorrow, but delight, / And miserable love that is not pain/ To hear of . . " (Prelude XIII, 245-247). Somewhere in Wordsworth's development as a poet, sorrow becomes delight (in the Burkean sense of absent pain), and we are left to wonder: what has happened to the Gothic body in the transformation?

To the degree that the Salisbury plain series is indebted to the Gothic, it contains those corventional Gothic images of pained bodies. In all of its incarnations, it is the story of a traveller, crossing the plain near stonehenge, who meets a poverty-stricken Female Vagrant in a deserted spital. This woman relates her story of hardship, illness, and her family's death in war-torn America, where she has been forced to follow her husband, press-ganged into service there.24 After his and their children's deaths, she returns to England to find her city ravagad by poverty, disease, and pain, a pain that magnifies her own. By moving through images of ancient barbarism--involving 
both American primitivism and Druidic sacrifice--and contemporary suffering brought on by war, the poem charts the effects of pain on human consciousness. Ultimately, it argues that the most intense suffering comes from "memory of pleasure flown" (ight. 21), and that a consciousness of happiness lost is the greatest hardship one can endure.

In the first version of the series, A Night on salisbury Plain, the Vagrant's pain is foreshadowed by a hypothetical description of an American native, a description which will contrast sharply with her own. The poem opens with a rather stark depiction of a "hungry savage," "naked and unhouzed, And wasted by the long day's fruitless pains..." (1-3). However, for the savage, suffering represents a kind of nobility, of a battle against the elements. Besides, he knows nothing different:

For happier days since at the breast he pined He never knew, and when by foes pursued With life he scarce has reached the fortress rude, While with the war-song's peal the valley's shake, What in those wild assemblies has he viewed But men who all of his hard lot partake, Repose in the same fear, to the same toil awake?

Just as Ann Radcliffe makes tableaux of social bonding out of pained bodies, so does Wordsworth find a virtue in suffering. The savage's pain actually connects him to a group of men "who 
all of his hard lot partake"; there is community here because everyone knows how everyone else feels. In fact, the savage is lucky because he is probably not as hard done by as many others: "how many thousands weep," proclaims the narrator, "Beset with foes more fierce than e'er assail/ The savage without home in winter's keenest gale" $(34-36)$. No matter how much pain he has suffered, his comrades in pain have suffered more. With a curious $\operatorname{logic}$, the poem immediately establishes pain as the unifying principle in a community of sufferers. As the observer felt a connection to Burke's hypothetical victim, a.d as the Radcliffe heroine shared the sufferings of the virtuous, so does the Wordsworthian savage feel comnected to others in pain.

The barbarous treatment that the savage felt at the wrath of nature is replayed by the treatment that other human being have received at the hands of the Druids on Salisbury Plain. This overwhelming pain connects the traveller to history as he hears a voice speak from the mountain, a voice warning him not to go there, lest he shoula partake of "endless tortures" (89) and "human moans" (94). Here again pain has a communalizing property, one which underlies the traveller's relationship to the Female vagrant as well as to the previous travellers on the Plain. When the traveller finds her in the spital, now named "the dead house of the plain" (126) because of its inability to support humas life, she has obviously been victimized by years of poverty, illness, and malnutrition. However, it is the purpose of the poem to have her tell her story and, in so telling, to 
publicize her physical afflictions. The medicinai value of this talking cure is made evident both in Nature and on the Vagrant's body:

While thus they talk the churlish storms relent;

And round those broken walls the dying wind

In feeble murmurs told his rage was spent.

With sober sympathy and tranquil mind

Gently did the Woman gan her wounds unbind.

$(199-203)$

The implications of this monologue are important. In Ann Radcliffe, suffering was made public property through the imaginative construction of image, through painting a mental portrait of how someone else feels. In Wordsworth, suffering is publicized through language, through the ability to tell one's story. As Elaine scarry has argued, language is itself an imaginative act, one that is intended to make known, among other things, our physical sentience:

though there is ordinarily no language for pain, undel the pressure of the desire to eliminate pain, an at least fragmentary means of verbalization is available both to those who are themselves in pain and to those who wish to speak on behalf of others. (p. 13) The Vagrant's tale is intended to let the traveller and us know how she feels.

But while language may be intended to externalize the internal, it occupies here that contradictory function that I identified in Burke and Radcliffe: on the one hand, language, as 
an act of imagination, attempts to embody physical suffering and make it social, but on the other hand, it replaces physical feeling as a way of communicating what is otherwise a totally internal, centripetal experience. Scarry's caveat that "there is ordinarily no ianguage for pain" is important here, as it is in Virginia Woolf's inability to describe a headache, or in a torture victim's inarticulate screams. Language as an imaginative act is often incompatible with pain as a physical experience, scarry argues, and therefore, language cannot communicate pain.2s This incompatibility expresses itself in a number of ways throughout the Vagrant's story. First, as she begins to catalogue the physical ailments that befell her and her family among America's war-torn "streets of want and pain" (301). she is brought up short in a significant preterition:

"The pains and plagues that on our heads came down, Disease and Famine, Agony and Fear, In wood or wilderness, in camp or town, It would thy brain unsettle even to hear. All perished, all in one remorseless year, Husband and children one by one, by sword And scourge of fiery fever: every tear Dried up, despairing, deselate, on board A British ship I waked as from a trance restored." $(316-324)$ The hardships here are swallowed up by a tactful silence-."It would thy brain unsettle even to hear"--and reported with an 
almost journalistic detachment. Neither her pains nor those of her family are given a language; in this new, contemporary America, the one much like England, pain is not socialized.26 Moreover, the private, nonverbal quality of this experience undermines the entire community of pain with which the poem opened. As the woman recounts her return to England, she describes herself in the context of a city in pain, a description which clearly invites us to compare it with the opening stanza describing the savage's community of pain. But this ona is quite different:

"Of noysome hospitals the groan profound, The mine's dire earthquake, the bomb's thunder stroke: Heart sickening Famine's grim despairing look:

The stormed town's expiring shriek that awoke Far round griesly phantoms of the dead, And pale with ghastly light the victor's human head.

"Some mighty gulf of separation passed I seemed transported to another world... ."

$(361-371)$

Gone is the poem's conviction that all sufferers are bonded; gonf is the Burkean optimism that we all share another's pain; gone is the blest assurance, suggested by the unself-conscious savage, that pain is insignificant as compared to that of others. Instead, the poem argues that, in pain, the self is rendered absolutely solitary and all-consumed. Pain splinters society 
into atoms of individual consciousness: "my only wish," admits the vagrant, was "to shun where man might come" (378).

A standard psychoanalytic reading of the argument in $\mathrm{A}$ Night on Salisbury plain would suggest that the solitariness of the Vagrant's experience is counteracted by her desire to teil the story and to have it be heard. Jacques Lacan has argued that our "desire finds its meaning in the desire of the other, not so much because the other holds the key to the object desired, but because the first object of desire is to be recognized by the other."27 For John Williams, the only redemptive possibility in Salisbury Plain is the "instinctive response of one desoluted human being for another," that by telling and hearing the story, the interlocutors diminish their terror in a bond of compassion.20 After all, the vagrant's story does remind us and the traveller that "He too had withered young in sorrow's deadly blight" (405). But how this young, healthy traveller can be said to have withered, in contrast to the woman, is not clear, and this shifting of the focus to his problems seems somewhat intrusive and selfish. Moreover, the poem makes clear that her very lack of desire to communicate with the other is the greatest hardship she has had to endure, in that she has lost that greatest of Wordsworthian virtues, hope. And while she does communicate to him a history of what she has gone through, she makes it clear that the pain she has endured is incommunicable; and desire to tell the story of her body is rendered superfluous. The imagination here has no language to speak its bodily pains. 
Therefore, it is significant that the poem's plot ends by the traveller and vagrant each about to take a "several road" with the benediction: "Adieu ye friendless hope-forsaken pair!" (415). The friendlessness, that unexpected interruption of community, ultimately proceeds from the inability to know another's suffering. Language, as issued forth by the imagination, is renciered unable to socialize one's physical experiences: storytelling does not. let me know how you feel. If the poem began with a highly sentimentalized depiction of the communality of the body in pain, it ends with a resignation to solitude.

Imagination and pain remain incompatible.

Pain's destruction of hope--and any other salvific force the imagination is capable of producing--is not confined to the individual sufferer in this poem. It is also political. By his own testimony, wordsworth conceived Salisbury Plain while trying to come to terms with England's declaration of war against France in 1793.29 Thus, there is a conscious political agenda underlying the Vagrant's story. To close A Night on Salisbury. Plain, the narrator--similar in tone to the young Jacobin Wordsworth--condemns English foreign policy for expanding its empire and fighting battles abroad while its people are starving at home (and indeed, it has been this irresponsible foreign policy, like the declarations of war against American and France, that has been directly responsible for the woman's poverty): The nations, though at home in bonds they drink The dregs of wretchedness, for empire strain, 
And crushed by their own fetters helpless sink, Move their galled limbs in fear and eye each silent link. $(447-450)$

That the body politic should sink helpless in fetters and fearfully move in galled limbs puts it directly in the same relationship to pain that Wordsworth was exploring in the woman's story. John Williams argues that Wordsworth uses Gothic imagery in this poem in order to condemn disasters incurred by political stupidity: the use of monstrous and grotesque images suggests an unnatural war waged by greed (p. 40). Eut the use of Gothic imagery also invokes the problems associated with pain in the body: the nation is "crushed," it moves "silently," oblivious to the external empires who indirectly cause its suffering. As in the individual body, the body politic is unable to experience anything but its own pain, and to sink helplessly under that pain.

The Gothic imagery in this passage also invokes the problems associated with viewing the Gothic body--that which is both sentimentaliy charged and in extreme pain. Just as the vagrant's pain isolated her from the community of sufferers, just as viewing pain and carnage cut her off from its political implications, so will Wordsworth use it to freeze and isolate the sensitive English citizen, the member of the body politic. Evoking the violent primitivism of Druidic savagery--a primitivism from which England has presumably progressed--the narrator asks: 
Though huge wickers paled with circling fire

No longer horrid shrieks and dying cries

To ears of Daemon-Gods in peals aspire,

To Daemon-Gods a human sacrifice;

Though Treachery her sword no longer dyes

In the cold blood of Truce, still, reason's ray,

What does it more than while the tempests rise,

With starless glooms and sounds of loud dismay,

Reveal with still-born glimpse the terrors of our way?

$(424-32)$

While the history of England may be one of civilization, of a move from barbarous human sacrifice to sophisticated parliamentary procedure, Wordsworth argues against English smugness for its progress. The ray of reason should illuminate the country's progress, both in its domestic and foreign policies. But instead, it simply illuminates a "still-born glimpse" of terror. The more reasonable and clear-sighted we become, the more we are able to see the pain and carnage we inflict. And so, the image of the "still-born" is fitting: the glimpse promises optimistic progess, but it is rendered powerless and lifeless by the magnitude of the carnage it reveals. Pain freezes us from political activity by cutting us off from a starless, gloomy, dismayed community, a community which English history has sought in vain to liberate from a barbarous past. The afflicted human body has been transported from Druidic 
sacrifice into contemporary government sacrifice, and with it comes the isolation and disempowerment of the political imagination.

When pain's vicissitudes throw into question the possibilities of community, and when the pains are redoubled by France's "horrid shrieks and dying cries," the result is for the poet to retreat further from the political implications of the body's immediacy in pain.30 such retreat is sounded in the 179599 Adventures on Salisbury Plain, which differs from its predecessor in a number of important ways. First, whereas the earlier poem focusses on an immediate relation of a tale of suffering, the later one displaces this immediacy by introducing an old sailor as the hearer of the woman's tale. And while the traveller of the previous poem seemed to be a mere sounding-board for the woman's story, the sailor is a much less ingenuous audience. He has murdered a man, and so the landscape, the gibbet, the painful bodies, and the reflections on justice have a particular impact on him. As his sense of guilt regulates the way he hears the story, we see what stephen Gill argues as the main effect of the revision: whereas the former poem was a meditation on the Vagrant's suffering, this poem is a meditation on a meditation on suffering.31 The Vagrant's hardship is of interest to the degree that it affects the sailor's emotional reaction to it.

The second major change deals with the way the painful body does or does not create community. In the earlier poem, we were 
presented with a suffering traveller who, like the savage, had tried to identify with another sufferer--indeed, with all sufferers--on the plain. In this poem we are introduced to an old man who is in pain--his "legs from slow disease distended were" (4), and his "withered arms" and "faltering knee" are a constant reminder of his mortality--but the communal suffering is not there. In this poem, the sailor does not share in the society of sufferers, but rather his "strong and stout" form is contrasted to the soldier's (14). And in this poem, pain thoroughly isolates the soldier; unlike the former traveller's, it is an experience only the sufferer can know. We remember that when the former traveller comes upon stonehenge, he has a sense of some historical connection to other sufferers. The sailor in Adventures has no such society:

Thou hoary Pile! thou child of darkness deep And unknown days, that lovest to stand and hear The desert sounding to the whirlwind's sweep, Inmate of lonesome Nature's endless year; Ever since thou sawest the giant Wicker rear Its dismal chambers hung with living men, Before thy face did ever wretch appear, Who in his heart had groan'd with deadlier pain Than he who travels now along thy bleak domain?

Suffering here, both physical and emotional, does not create the kind of community for which Burke, Radcliffe, and the earlier 
traveller had hoped: like the Vagrant's pain in the earlier version, it is private and ineffable.

On the one hand, then, Adventures increases its emphasis on the contemplation of suffering, while on the other it decreases the sociability of the body doing the suffering. The body, as it exists gua body, is depicted with increasing distance and isolation. As Mary Jacobus argues, wordsworth puts the phenomenon of suffering--and any significance it might have-squarely within the imagination, outside the purview of the shared community.32 This movement, I believe, explains the third major change Wordsworth makes in the Salisbury Plain series, that is, the addition of three vignettes at the end of Adventures. Whereas the previous poem ends with a propagandistic diatribe against the politics of war, this poem ends with three meditations on human suffering, and on what can be learned from them. The first vignette depicts a father's physical abuse of his disobedient child. The scene concludes with the father gazing upon the cuts and bruises he had administered, and such sight the father of his wrath beguil'd;

Relenting thoughts and self-reproach awoke; He kiss'd the boy, so all was reconcil'd. (653-5) It's that easy. But more to the point, the scene reminds the Sailor of his own violent past. As he looks on the boy's headwound, he makes a train of associations that take him back to the murder he had committed: "The head with streaming blood had dy'd the ground,/ Flow'd from the spot where he that deadly wound/ Had 
fix'd on him he murder'd" (643-645). For both the father and the Sailor, the wounded body is evoked solely for the way it can engage the salvific force of an internal conscience: suffering is somehow justified if it can induce guilt.33 Similarly, the second vignette presents a dying woman lying "spent and gone" with "wasted limbs" $(698,702)$. This woman, it turns out, is the sailor's wife, whom he had abandoned after the murder and who has suffered in poverty ever since. The sight of her dying body, coupled with the agitation and "correspondent calm" he had felt at the sight of the abused child (666), induce him to make a full confession. But at her death bed, it is he who appears to be in the greater agony. He requests, "O bless me now, that thou shoulds't live/ I do not wish or ask: Eorgive me, now forgive!" (773-774) Once again, the dying body is viewed only for what it can invoke inside the observer. And finally, in the last vignette, the sailor is hung in a gibbet to become a spectacle for "dissolute men, unthinking and untaught" (820). But, we are told, we should not flinch at the pain he undergoes here any more than he sympathized with the previous victims, because some good may come of it: some potential criminal may come, "Upon his swinging corpse his eye may glance/ And drop, as he once dropp'd in miserable trance" (827-8). In the spectator's "miserable trance" the criminal's pained body is invested with a redemptive potential. Indeed, all three of these added moments use the body to elicit a purification of the observer. But in so doing, the sentimental process they employ enacts a division 
between the body and the observer, in that the body is seen and then ignored in favour of a privileged, internal conversion. The miserable trance becomes the psychological space in which the pained body is displaced by an imaginative process whose object is itself.

In the third and final version of the poem, Guilt and Sorrow: or Incidents upon Salisbury Plain, which Wordsworth published in 1841, the ending scene undergoes yet another significant revision. In this version, the sailor is again captured by the townspeople, after making a full confession. But whereas before they hung him in a gibbet as an inspiration to other criminals, this time

His fate was pitied. Him in iron case (Reader, forgive the intolerable thought)

They hung not:--no one on his form and face Could gaze, as on a show by idlers sought; No kindred sufferer, to his death-place brought By lawless curiosity or chance, When into storm the evening sky is wrought, Upon his swinging corse an eye can glance, And drop, as he onse dropped, in miserable trance. (658-666, emphasis original)

That the poet here is expounding pity over justice is unlikely: "no kindred sufferer" is to reap the benefits of this punishment by pitying the pained body. But such a pity would have been distateful to Wordsworth by the time this poem was published: the 
same year that saw the publication of Guilt and sorrow also produced Wordsworth's Sonnets Upon the Punishment of Death, in which he argued against the whig law reforms, and advocated capital punishment in cases of treason and murder. Rather, Wordsworth seems to be shying still further away from presenting the pained body, and he is doing so, I would suggest, in order to increase its effect on the imagination. We are told to "forgive the intolerable thought," which assumes that we are supposed to have such a thought; we are supposed to imagine the criminal body and the suffering it is going through. (Otherwise, there would be no point in bringing up the scene of the gibbet, since, unless one has read the prior Adventures., one would have no reason to expect the sailor to be hung in the first place; without an image of the suffering body already in our imaginations, this stanza makes no sense, and is out of place.) Then, we seem to be instructed, via negativa, on how to respond to the body we imagine. We are supposed to fear the punished body which we imagine; we are to take a lesson from our own conscience, a lesson that exploits the pained body while at the same time avoiding the freezing, the Radcliffean horror, the "miserable trance" that an actual presentation of that body might produce.34 In the following two chapters, I will discuss more fully the role of the imagination in state regulation and jurisprudence, and the move toward what Foucault calls the "gentle way of punishment." For now, suffice it to argue that, by removing the image of the pained body from the end of Guilt and Sorrow, Hordsworth seems to 
want us to conjure it all the more. The "intolerable thought" seems much more tolerable--and much more effective--than an actual pained body.

The Salisbury Plain series, then, is among other things a response to the problem of socializing a pained body through an act of the imagination--a body which cannot be imagined. This hermeneutic problem, and the strategies which Wordsworth uses to circumvent it, earned him Hazlitt's condemnation that he "takes on a subject or story merely as pegs or loops to hang thought and feeling on,"3s so that the real lives and pains of Wordsworth's characters become nothing but convenient ciphers through which to propound doctrine. (And, pace Paul sheats, the object is not treated as object, but as a source of imaginative speculation.) Furthermore, by the publication of The Excursion in 1814, that intense feeling borders on becoming what Hazlitt calls "the God of [Wordsworth's] own idolatry" (p. 216). This condemnation of Wordsworth's egotism finds its contemporary voice in David Ferry, who initiated the current critical strain that wordsworth is unable to sympathize with another person without egocentrically assuming center stage in the process. Indeed, Ferry says it is easy to see Wordsworth "not as a great lover of man but almost as a great despiser of him."36 such a condemnation, however, begs the theoretical question as to what language wordsworth should have used to portray physical suffering. If he presents pain directly, with Gothic graphicness, can he not be condemned for exploiting that pain for sensational ends?37 or, might he not be 
exploiting pain in order to demonstrate his own sensitivity, as does the sailor in Adventures? But on the other hand, if he avoids speaking of pain directly, does this not show a marked insensitivity to the experiences of others? Either way, Wordsworth can be condemned, if one should want. 38 But if we add to this scarry's argument that there is no language to describe pain, then we may see the driving force behind Wordsworth's revisions of his Gothic past in those early years. If Wordsworth tropes his characters' sufferings into something else, it is because he may have been facing a lexical impossibility, one that proceeds directly from the impossibility of imagining--and hence, of imaqing--pain.

This linguistic impossibility has "political" implications in two senses of that word. First, it isolates the individual within a context of others, an isolation which, in Ann Radcliffe, was effected by the imagination's inability to sustain a figure of pain. Like Radcliffe's heroines (although with considerably more censure), Wordsworth uses pain to isolate, rather than to socialize his ego. Second, like Radcliffe, the problem is political in the sense of Wordsworth's own reaction to the carnage of the French Revolution. In 1792, just before beginning the Salisbury Plain series, Wordsworth returned to Paris, cheered by the thoughts that the violence had ended (Prelude $x, 48$ ). But what he found in the square of the Place de Carrousel disheartened and confused him: he found a heap of dead and dying bodies, which he looked upon 
as doth a Man

Upon a volume whose contents he knows

Are memorable, but from him locked up,

Being written in a tongue he cannot read;

So that he questions the mute leaves with pain,

And half-upbraids their silence. ( $x, 58-63)$

Like the bodies in the London of Salisbury Plain, the victims of war here are incomprehensible, unimaginable--they elide a hermeneutic by which to understand the magnitude of the carnage. David Gervais argues that Wordsworth was all too aware of how excessive passion could be anesthetizing and self-thwarting: "Too much feeling might become none."39 As in the earlier poem, the spectator remains outside an imaginative framework which can make sense of such pain. It is not until wordsworth is in his hotel room, alone and at a distance, his emotion recollected in tranquillity, that he can feel anything more distinct than confusion; and this feeling is not "wholly without pleasure" $(\mathrm{x}, 68):$

With unextinguished taper I kept watch, Reading at intervals; the fear gone by Pressed on me almost like a fear to come.

I thought of those september massacres, Divided from me by one little month, Saw them and touched; the rest was conjured up From tragic fictions, or true history, Remembrances and dim admonishments. (X,70-77) 
The textuality of suffering and death is not new to us: we have seen it before in Adeline st. Pierre, who had read the fractured MS. of her father's fractured body; we have seen it in Emily, who read the "plain and dreadful story" of the hieroglyphics at the gibbet site; and we have seen it in the young wordsworth, who read the monumental letters on the heath of the Plain. And like those former experiences with imagining pain, wordsworth's experience of the Revolution required that he fictionalize the body in order to comprehend it. The strong emotion elicited from him by these dead and dying bodies is a strong emotion which he has demonstrated elsewhere he is incapable of feeling, without the help of some saving intermediary.

Wordsworth's experience of the Revolution initiated in rim a crucial first step in the construction of a political conservative. By exploring the limitations of the body in pain, Wordsworth was forced to read meaning into that body, even if it meant displacing it from its status as subject to its status as object. By becoming object, the body acts as a place for Wordsworth to begin a individualizing process which, in turn-ofthe-century politics, is a conservative one. As Graham Pechy puts it,

Wordsworth represents a moment of withdrawal in which the aesthetic is detached from the political and a new aesthetic radicalism is founded upon the category of 'feeling'; in the space vacated by politics a transhistorical community is projected.10 
Which brings us back to Burke, and to Ann Radcliffe. When Burke argued that the pleasure of pain required a certain distancing in order to be pleasurable at ald, he established an essential structural principle that would underlie his Reflections on the Revolution in France. For Burke, France's horrors came far too close to England for comfort, and his "aesthetic" required that they be kept at a distance. But this aesthetic is the fear embodied by a political conservative, one who is ultimately interested in protecting the imagination from foreign influence, one who fears, more than anything else, an identification with the suffering of the French body politic. In Ann Radcliffe's Gothic, this aesthetic took the form of a dialectic of imagination, in which one sympathetically identified with a community of sufferers in order to isolate onsele more fully from them. Aesthetic distancing was inscribed at the very site of aesthetic experience: the sympathetic human body. In wordsworth, that distancing is reified even more strongly, and made into an intellectual, poetic system. The sacred space which is the site of poetic genius is also the space to be kept free from the emotionally charged suffering of the other-the other as it is so dangerously figured in the suffering French revolutionary. 
Notes

1. Wordsworth, The Fourteen-Book "Prelude", Book XII, 231-240.

2.Ann Radcliffe, The Mysteries of Udolpho (New York: Oxford University Press, 1986), p. 54 .

3. The description of the gibbet as appended to the first MS., A Night on Salisbury Plain, reads as follows:

Yet though to each sympathy inclined

Most trivial cause will rouse the keenest pang

of terror and oerwhelm his mind

For then with scarce indistinguishable clang

In the cold wind a sound of irons rang.

He looked and saw on a bare gibbet nigh

In clanking chains a human body hang

A hovering raven oft did round it fly

f grave the was beneath which he could not descry.

See William Wordsworth, The Salisbury Plain Poems of William

Wordsworth, ed. Stephen Gill (Ithaca: Cornell University Press, 1975), P. 116 .

4.According to John Williams, James Beattie's The Minstrel was Wordsworth's most important model during the mid-17s0s, when he was experiencing Salisbury $\mathrm{Plain}$ and writing about it (see Wordsworth: Romantic Poetry and Revolutionary Politics [New York: Manchester University Press, 1989], p. 71). The Minstrel is also the poem to provide numerous chapter epigraphs for Radcliffe's 
novels.

5.James $H$. Averill notes that the gibbet scene in The prelude focusses on what isn't there--bones, iron, a wooden mast; there is only a tuft of grass which might exist anywhere. See Wordsworth and the Poetry of Human Suffering, p. 245 .

6. It is now a critical commonplace that one of Udolpho's most outstanding characteristics is that nothing happens in it.

supernatural events are all exposed as having natural causes, and perceived dangers are mostly constructions of Emily's frenzied imagination. For discussions of these non-events, see Nelson Smith, "Sense, Sensibility, and Ann Radcliffe," ștudies_in English_Literature 12 (1973): pp. 557-570; D.L. Macdonald, "Bathos and Repetition: The Uncanny in Radcliffe," Journal of Narrative Technique 19 (1989): pp. 197-204; and Day, Circles. 7.William Wordsworth, "Preface to Lyrical Ballads," in prose Vol. I, p. 128 .

8. For a discussion of Radcliffe's debt to Burke, see Coral Ann Howells, Love, Mystery and Misery: Feeling in Gothic Fiction (London: Athlone Press, 1978). On Wordsworth's debt to Burke's Enquiry, see W.P. Albrecht, "Tragedy and Wordsworth's sublime," The Wordsworth Circle 8 (1977): pp. 83-94; Patrick Holland, "Wordsworth and the sublime: Some Further Considerations," The Wordsworth Circle 5 (1974): pp. 17-22; and w.J.B. Owen, "The sublime and the Beautiful in The Prelude," The Wordsworth Circle 
4 (1973): pp. 67-86. On the influence of Burke's Reflections on Revolution, see Mary Jacobus, "That Great Stage where Senators Perform': Macbeth and the Politics of Romantic Theatre," studies in Romanticism 22 (1983): pp. 353-387; and James K. Chandler, Wordsworth's Second Nature: A Study of Poetry and Pol itics (Chicago: University of Chicago Press, 1984).

9. Burke's sympathetic connection is echoed by the nun olivia in Radcliffe's The Italian. She says to Ellena:

- . I think I could endure any punishment with more fortitude than the sickening anguish of beholding such suffering as I have witnessed. What are bodily pains in comparison with the subtle, the exquisite tortures of the mind! Heaven knows I can support my own afflictions, but not the view of those of others when they are excessive. The instruments of torture I believe I could endure, if my spirit was invigorated with the consciousness of a generous purpose; but pity touches upon a nerve that vibrates instantly to the heart, and subdues resistance. Yes, my child, the agony of pity is keener than any other, except that of remorse, and even in remorse, it is, perhaps, the mingling unavailing pity, that points the sting. (The Italian, or The Confessional of the Black Penitents: $A$ Romance [New York: Oxford University Press, 1986], pp. $127-128$ ) 
10. Quoted in Bonamy Dobree's Introduction to Udolpho, p. ix.

11. Devendra Varma, The Gothic Elame (New York: Russell and Russell Ltd., 1966), p. 145.

12. Ann Radcliffe, The Romance of the Forest (New York: Oxford University Press, 1986), p. 228. All further quotations from the novel will be cited in parentheses in the text.

13. It is such playful narration that Mark M. Hennelly Jr. writes about in "The slow Torture of Delay': Reading The Italian," Sludies in the Humanities 14 (1987): 1-14. Another example of imagining pain--pain which doesn't exist--occurs when Ellena and Vivaldi have been locked in the prison by Jeronimo. As the level-headed Vivaldi tries to procure a means of escape, Ellena. . Erequently looked round the chamber in search of some object, which might contradict or confirm her suspicion, that this was the death-room of the unfortunate nun. No such circumstance appeared, but as her eyes glanced, with almost phrenzied eagerness, she perceived something shadowy in a remote corner of the floor; and on approaching, discovered what seemed a dreadful hieroglyphic, a mattress of straw, in which she thought she beheld the death-bed of the miserable recluse; nay more, that the impression it still retained, was that which her form had left there. (p. 140) 
14.Brissenden uses the OED definition of virtue as "refined and elevated feeling" to discuss the moral crisis which such feeling underwent in a fallen material world. His thesis is that the sentimental response to virtue in distress ultimately collapsed into a pejorative connotation of virtue as ""indulgent, superficial emotion" because that virtue was too ambitious. "The sentimental tribute of a tear exacted by the spectacle of virtue in distress was an acknowledgement at once of man's inherent goodness and of the impossibility of his ever being able to demonstrate that goodness effectively" (ㅁiue, p. 29). In Radcliffe's case, the physical response to imagined pain is the "sentimental tribute", but one which must fall short of its goal because of its self-destructive potential as horror which freezes the very sensibility which invited it.

15. Emily's substitution of herself for the victim, replayed at the phenomenal level by her actually sitting in the torture chair, is borrowed by Bram stoker and reproduced almost verbatim in a short story called "The squaw." In this story, a company of observers visit a museum of torture and one, in sympaiby with the pain that must have been suffered, seats herself in the torture chair. It is not clear whether stoker's use constitutes plagiarism or parody, since the Gothic is so highly indebted to both. 
16. April London, "Ann Radcliffe in Context: Marking the Boundaries of The Mysteries of Udolpho," Eighteenth-Century Life $10(1986):$ p. 46 .

17. "I deology".

18. See John Locke, "Two Treatises on Government," in The Works of John Locke Vol IV (Darmstadt: Scientia Verlag Aarlen, 1963), pp. 353-354.

19.Smith, "Sense, Sensibility, and Ann Radcliffe," p. 583.

20. For this reason, Jane Austen's rebuke of Radcliffe in Northanger Abbey has always seemed to me slightly unfair. Austen argues that "it was not in [Mrs. Radcliffe's] works perhaps that human nature. . was to be looked for.." (The Complete Novels of Jane Austen [New York: Random House, n.d.], p. 1176), an argument repeated in Emma where Harriet Smith is satirized for reading The Romance of the Forest. Rather, Catherine Morland is instructed to look for real problems, not to invent them through imagination. st. Aubert counsels Emily in something very similar, and Radcliffe is as concerned as Austen about reinstating the value of sense over sensibility. Furthermore, both authors tie that sense into the right to hold land and power. Austen is as horrified as Radcliffe at the thought that one should marry far beneath or above her, and "proper" marriages in Austen always legitimate the owning of estates and lands. 
21.Paul Sheats, The Making of Wordsworth's Poetry, 1785-1798 (Cambridge, MA.: Harvard University Press, 1973), p. 8.

22. Enid Welsford, Salisbury Plain: A study in the Development of Wordsworth's Mind and Art (Oxford: Basil Blackwell, 1966), pp. 68 .

23.William Wordsworth, "Lines Written a Few Miles Above Tintern Abbey," in The Oxford Authors: William Wordsworth, ed. Stephen Gil1 (New York: Oxford University Press, 1989), 1. 97.

24. This sto:y, changed very little in revisions, becomes "The Female Vagrant" in Lyrical_Bal lads.

25.For Eve Kosofsky Sedgwick, this unspeakability is a Gothic convention. She traces in Melmoth the Wanderer examples of preterition--that rhetorical device of claiming not to be able to describe something--and concludes that language is "a sort of safety valve between the inside and the outside which being closed off, all knowledge, even when held in common, becomes solitary, furtive, and explosive". To speak, therefore, would be to transgress an artificial barrier that would collapse the outside world of listeners into the inside world of the sufferer. This collapse, in the Gothic, signals chaos. See The Coherence of Gothic Conventions (New York: Methuen, 1986), Pp. 16-22.

26. In his personal life, Wordsworth was aware of how pain could inhibit the production of language. In 1798 he wrote to Coleridge from Goslar, Germany: 
As I have had no books I have been obliged to write in self-defence. I should have written five times as much as I have done but that I am prevented by an uneasiness at my stomach and side, with a dull pain about my heart. I have used the word pain, but uneasiness and heat are words which more accurately express my feeling. At all events it renders writing unpleasant. Reading is now become a kind of luxury to me. When I do not read I am absolutely consumed by thinking and feeling and bodily exertions of voice or of limbs, the consequence of those feelings. (Ernest de selincourt [ed.], The Letters of will iam and Dorothy Wordsworth.

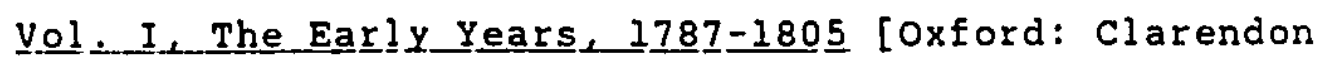
Press, 1967], p. 236)

The pain in the stomach and side were no doubt occasional; unlike most other writers of Romantic fiction, Wordsworth did not seem plagued by chronic ill-health. But the link in the final sentence between imagination and sentience is interesting: thinking and feeling (what becomes recollection and emotion in The Prelude) are physically exhausting. Bodily exertions of voice and limbs are their consequence. Thus, literary endeavors overstimulate the body and tire--or even hurt--it, making writing impossible. Here, the imagination of pain seems to destroy itself in the way it did with Radcliffe's heroines. 
27.Jacques Lacan, "The function and field of speech and language in psychoanalysis," in Ecrits: A Selection, trans. Alan Sheridan (New York: พ.W. Norton and Company, 1977), p. 58.

28. Romantic Poetry, pp. 78-79.

29. See the Advertisement to Guilt and Sorrow: or. Incidents Upon Salisbury Plain, in Gill, Pp. 215-217.

30.For Enid Welsford, Wordsworth's retreat from the body is inspired by a Radcliffe-like sense of decorum: "The pruning away of much--not by any means all--of the 'Gothic' horror of MS.I may be due to Wordsworth's increased reverence for matter-of-fact as well as the natural development of good taste" (Salisbury Plain: study, p. 28).

31."Introduction" to The Salisbury plain Poems, pp. 12-13. 32." That Great Stage'."

33. This is a theme which Wordsworth shares with Coleridge, with whom he co-published part of this poem as one of the Lyrical Ballads. For a discussion on Coleridge and the politics of guilt, see the discussion on Osorio and Remorse in the next chapter.

34.Seraphia D. Leyda argues that, in the Sonnets Upon the Punishment of Death, Wordsworth is combining a doctrine of love with a doctrine of fear:

Blending the 'several powers' of Love and Fear implies 
some imaginative power and clearly challenges any overreliance on deductive reasoning from a set of utilitarian principles. Man responds to love, but fear is often stronger. Wordsworth, in this sense, is urging the lawgivers to legislate for the "real" world by retaining for the state the last alternative of Life or Death" ("Wordsworth's Sonnets Upon the Punishment of Death," The Wordsworth Circle 14 (1983), p. 50 .

35.William Hazlitt, "Mr. Wordsworth," in Lectures on the English Poets.s and spirit of the Age. or Contemporary Portraits (New York: Dutton Publisining, 1967), p. 253.

36. David Ferry, The Limits of Mortality: An Essay on Wordsworth's Major Poetry (Middleton, CT.: Wesleyan University Press, 1959), p. 52. Edward Bostetter argues that the French Revolution made Wordsworth aware of the social and political causes of suffering, and so his glossing over them in The Ruined cottage and "The Discharged soldier" can have no ethical justification (The. Romantic Ventriloquists: Wordsworth, Coleridge, Keats, Shelley, Byron [Seattle: University of Washington Press, 1963], p. 53). Bostetter has in mind that contentious line near the end of The Ruined_Cottage when the old Man, having just related the sufferings of Margaret, concludes, "I turned away/ And walked along my road in happiness" (in Gill, oxford Authors, 11. 524525 ). 
37.For James H. Averill, this is precisely what Wordsworth did not want to do, and his contemplation of his own ego at the centre of others' suffering is Wordsworth's way around the problem. See Wordsworth and the Poetry of Human Suffering.

38. Averill argues that Wordsworth's increased unwillingness to contemplate human suffering results in his sterility and decline as a poet (ㅂuan suffering, p. 283). Conversely, Karen Swann suggests that Wordsworth takes distance from suffering bodies in order to avoid "the gothic, sensational limits that take a reader in completely" ("Suffering and Sensation in The Ruined Cottage," PMLA 106 [1991], p. 87).

39.David Gervais, "Suffering in Wordsworth," The Cambridge Quarterly $16(1987)$, p. 12 .

40.Graham Pechy, "1789 and After: Mutations of 'Romantic' Discourse," in Barker et al (eds.), 1789: Reading,Writing, Revolution, p. 62. Andrea Henderson writes that the poem presents the poet as on a threshold; it

reflects a first and ultimately unworkable response to Wordsworth's personal and political disillusionment. The poem presents a world frozen mid-change, incapable of moving towards an enlightened future or recovering an unfallen past. Wordsworth, finding no clear place for himself, makes himself central in the world of the poem by constructing the poet as the one who restores wholeness by self-consciously aleinating what is at 
present only partially alienated. ("A Tale Told to be Forgotten: Enlightenment, Revolution, and the poet in 'Salisbury Plain'," studies in Romanticism 30 [1991], p. 72) 
Chapter Three:

Spectacular Pain: Politics and the Romantic Theatre

The phrase "Romantic theatre" seems somewhat of an oxymoron. If we take Percy Bysshe Shelley's The Cenci as an example, we are faced with the impossible task of putting on stage a Romantic idea. On the one hand, shelley wanted to present in Beatrice's story a "sad reality," "that which has been." This realism was to part from his previous, more idealistic works, those "visions which impersonate my own apprehensions of the beautiful and the just."l on the other hand, shelley sought in The cenci to "increase the ideal, and diminish the actual horror of the events," so that the pleasure of the poetry might "mitigate the pain of the contemplation of the moral deformity from which they spring."2 shelley's problem is one of presenting acts of extreme violence--in this case, rape and parricide--without succumbing to the Gothic excess which characterized the stige in the early nineteenth century. Unlike Prometheus unbound, whose first three acts preceded the writing of The Cenci in 1819, Shelley's foray into realism was firmly intended for the stage. Shelley wrote to his publisher Charles Ollier, on 13 March 1820, that, although The Cenci had been refused by Drury Lane, it was "expressly written for theatrical exhibition. . . . I believe it singularly fitted for the stage."3 But while this "fitting" for the stage is the representation of characters as they "really 
were," it is also haunted by the desire to idealize the reality, and to make the "Imagination.. . [an] immortal God which should assume flesh for the redemption of human passion."s The theatre here is to assume flesh, to represent material, bodily fact, only in order to transcend that materiality, and to elevate human passion into shelleyan idealism.

While shelley tried to revolutionize the stage by transforming the poetry of dramatic tragedy, his contemporary playwrights Coleridge and Byron entertained no such grand claims. Coleridge momentarily hoped to make a living by writing for the stage, but he had to admit that "I have no genius that way,"6 and as such did not honestly expect his playwrighting to be a success. In a letter to John Thelwall of 16 October 1797 , Coleridge christened his new play, Osorio: "oh, my Tragedy! it is finished, transcribed, and to be sent off today, but I have no hope of its success, or even of its being acted."7 (Coleridge was not disappointea: Osorio was rejected by Drury Lane and not produced until 1813, when it resurfaced as the revised Remorse.) Byron had even fewer pretensions to theatrical revolution. In the "Preface" to his Marino Faliero, Doge of Venice, he claimed, "I have had no view to the stage; in its present state it is, perhaps, not a very exalted object of ambition... . "8 on 23 August 1821, he wrote to John Murray about his joint publication of Sardanapalus and The Two Foscari,

I admire the old English dramatists--but this is quite another field-- 8 has nothing to do with theirs--I want 
to make a reqular English drama--no matter whether for the stage or not--which is not my object--but a mental theatre-- - -9

Byron does not explain what he means by a "regular" drama, but he clearly does want it to exist internally, to be read in the closet and to be performed on the stage of the mind. spectacle is not his interest.

While Coleridge and Byron share little of Shelley's design for the theatre, they do share with him a disdain for the state of the stage at the present time. With the success of bloody Gothic melodramas like Matthew Lewis's The Castle Spectre (1798) and Charles Robert Maturin's Bertram; or. The Castle of Aldobrand (which Byron actually liked, to but Coleridge panned), the stage had become the site of excessive violence, fevered emotion, and special effect.12 In Lewis's The Castle spectre, for example, a ghost is haunting the castle to avenge her murderer. And with the taste for the graphic which Lewis loved to indulge, her murdered body appears on stage to increase the shock of the crimes committed against her. The stage direction reads:

The folding-doors unclose, and the oratory is seen illuminated. In its centre stands a tall female figure, her white and flowing garments spotted with blood; her veil is thrown back, and discovers a pale and melancholy countenance; her eyes are lifted upwards, her arms extended toward heaven, and a large wound appears on her bosom. 12 
This ostentatious display of the wounded body occurs again when, at the concluding and climactic scene, the ingenuous heroine Angela dispatches the villain. She "springs suddenly forwards, and plunges her dagger in Osmond's bosom, who falls bith a loud groan. . ." (p. 98). Similarly, Bertram and Aldobrand, the rival characters in Maturin's Bertram, both die on stage, each succumbing to a thrust of the poniard and expiring in a pool of his own blood. These dramas seem to express a nostalgia for the days of Jacobean drama in which the staging of bloody murders was commonplace, days before Restoration tragedians like Dryden and otway cleaned up all traces of excess from the stage. But more to the point, Gothic dramatists like Lewis and Maturin always had their eye on the main chance: stage violence was immensely popular in both Covent Garden and Drury Lane, and the packed houses would net a playwright like Lewis an impressive $£ 18,000$ for The Castle Spectre's three-month run.13

When Shelley, Coleridge, and Byron take their places on--or off--the stage, they choose as their subject matter extreme and volatile situations: political revolution, murder, rape, torture -tyrannies both political and domestic. But they choose these subjects with a conviction not to contribute to the immensely popular Gothic theatre that defined public taste.14 For shelley, the mitigation of pain and horror was intended to teach "the human heart, through its sympathies and antipathies, the knowledge of itself...". . . Coleridge hoped in osorio to capitalize on "the anguish and disquietude arising from the self- 
contradiction introduced to the soul by guilt, a feeling which is good or bad according as the will makes use of it. . . " 6 And finally, "What I seek to show in 'the Foscari's'," wrote Byron, "is the suppressed passions--rather than the rant of the present day."l In all cases, these komantic playwrights seek to move the excess of spectacle off-stage and make the real site of theatre a more internalized, mental, pedagogical one.lB As Mary Jacobus argues, the Romantic theatre banished from the stage the image of violence because it sought to relegate it to the imagination, where it could be worked upon, formed, and controlled.19

The Romantics' suspicion of theatrical excess illuminates a political ambivalence. On the one hand, theatre is the most embodied of literary art forms. As shelley's Preface indicates, in the theatre the imagination assumes flesh, a flesh which lives, breathes, and is subject to political forces, oppressions, and pains. But on the other hand, this embodiment carries with it the possibility of ideological, rhetorical force. I noted in chapter one that the presentation of pained bodies could induce sympathy either for wordsworth's hunger-bitten girl, or with Burke's Louis XVI. Moreover, that rhetorical force could itself be a form of tyranny. Shelley dedicated The Cenci to Leigh Hunt because of the latter's "patient and irreconcilable enmity with domestic and political tyranny and imposture."20 strictly speaking, "imposture" is a feigned representation of self which is then enforced upon other people; it is an act of theatre. For 
Shelley, it is also an act of political tyranny: it is the assumption of false authority, as the tyrant claims a power to which he has no legitimate claim. As Jonas Barish suggests in his discussion of the "antitheatrical prejudice," 1 theatre represents the ambiguous boundaries of legitimate selfrepresentation, in which one can present "the facts" or in which one can impose upon those facts an ideological agenda. The "imposture" of theatre, then, can either expose of replicate the imposture of a tyrant like Francesco Cenci. I want to suggest here that these problems in representation not only inform the work of Romantic playwrights, but actually bring into sharp focus the problem of spectacle's rhetorical effects in that most prominent of theatrical tyrannies, the French Revolution.

As John David Moore points out, drama in the early nineteenth century came to be seen "in terms of an opposition between a high art blessed by tradition and a vulgar popular art - ." (p. 444). This "popular" art, as Foucault and Paulson have demonstrated, was associated with popular political movements and, albeit in a fantastical way, represented the struggles of the middle-class hero over the aristocratic tyrant, the nouveau over the ancien regime. 22 For a writer such as Coleridge (in his later, conservative years, after 1797), popular theatre was "identified with Jacobinism, which rose up from below and threatened the life of the more dignified tradition." 23 In a letter published in the second part of The Friend, Coleridge 
lashes out at Gothic and Sentimental playwrights who make it their business to transform moralists into villains, criminals into heroes, the poor into the rich, and the rich into the poor: the whole system of your Drama is a moral and intellectual Jacobinism of the most dangerous kind, and those common-place rants of Loyalty are no better than hypocrisy . . . For the whole secret of dramatic popularity with you, consists in the confusion and subversion of the natural order of things in their causes and effects, in the excitement and surprize, by representing the qualities of liberality, refined feeling, and a nice sense of honour (those things rather, which pass among you for such) in persons and in classes of life where experience teaches us least to expect them; and by rewarding with all the sympathies that are the dues of virtue, those criminals whom Law, Reason, and Religion, have excommunicated from our est eem!24

By "representing"--or rather "misrepresenting"--virtue, Gothic theatre enacts for coleridge a destruction of the moral order. The theatrical is always political, and the Gothic, to coleridge, subversive.

Conversely, the political is also theatrical. At the end of the eighteenth and beginning of the nineteenth centuries, says Moore, the "events of the French Revolution, that period's prototype of social upheaval, were described and analyzed by Tory 
and Jacobin alike in terms of a stage drama. The Revolution was theatre" (p. 446).23 For Edmund Burke, the storming of Versailles on 6 october 1789 was an "atrocious spectacle" ( $p$. 175), what Moore calls a "tragedy succeeded by the hideous burlesque of the populace" (p. 446). As Burke describes it in Reflections on the Revolution in France, the Revolution has all the characteristics of the Gothic theatre that the Romantics profoundly loathed. In his famous attack on Richard Price, whose speech at the old Jewry helped to crystallize the Jacobin movement in England, Burke equates Jacobin enthusiasm with the Gothic theatre:

Plots, massacres, assassinations, seem to some people a trivial price for obtaining a revolution. A cheap, bloodless reformation, a guiltless liberty, appear flat and vapid to their taste. There must be a great change of scene; there must be magnificent stage effect; there must be a grand spectacle to rouze the imagination, grown torpid with the lazy enjoyment of sixty years security, and the still unanimating repose of public prosperity. The Preacher [Price] found them all in the French revolution. This inspires a juvenile warmth through his whole frame. His enthusiasm kindles as he advances; and when he arrives at his peroration, it is in full blaze. (pp. 156-157)

Burke's antitheatrical prejudice here is one he shares with Rousseau, whose Letter to $M$.'Al embert on the Theatre argues 
that the theatre is nothing but an attempt to fill an otherwise empty life with amusement.26 But it is not just any theatre that Burke condemns here: it is the theatre of excess, of violent assassinations and massacres, spectacular pain which comprises "magnificent stage effect" and "grand spectacle." Burke notes with horror how, following the raid on the bedchamber, two of the King's gentlemen, "with all the parade of an execution of justice, were cruelly and publickly dragged to the block, and beheaded in the great court of the palace. Their heads were stuck upon sticks, and led the procession..." (pp. 164-165). The theatre of revolution here is detestable because it is extreme, violent, and public. Revolutionary sympathy, Burke implies, proceeds from the same bad taste that buys tickets to Matthew Lewis--the taste, dulled to torpidity, that can only be excited by excessive, bloody spectacle.

Burke's disdain for the public spectacle of violence is, at another level, a disdain for the public spectacle of the body. Civilization, he argues, is a tasteful clothing of society in proper behavior and sentiment, but in the Revolution, "All the decent drapery of life is to be rudely torn off" (p. 171). Burke's fear that the decent drapery be torn of $f$ is most clearly expressed in his treatment of Marie Antoinette who is, for him, the victim in this Gothic spectacle. When he had first seen her sixteen years prior, she had presented herself in a kind of theatrical glory: "I saw her just above the horizon," he writes, "decorating and cheering the elevated sphere she just began to 
move in,--glittering like the morningstar, full of life, and splendor, and jny" (p. 169). Here the Queen's body was draped, adorned, and, moreover, distanced, bathing in the glory of a spectacle as she moved above the crowd. But in the Gothic spectacle of the Revolution, her body is denuded and rendered immediate. As the bedchamber is invaded,

this persecuted woman had but just time to fly almost naked, and through ways unknown to the murderers had escaped to seek refuge at the feet of a king and husband, not secure of his own life for a moment. ( $p$. 164)

For Burke, the crime here is that Marie Antoinette's body is rendered both visible and vulnerable. She is threatened with becoming that female figure which Matthew Lewis would stage so successfully, the figure whose veil is thrown back, whose arms are extended in display and supplication, and who shows a large wound upon her bosom. Gothic spectacle, by indulging its love of the gratuitously violent and spectacular body, strips the Queen of human decency. That ain't no way to treat a lady.

Against the Gothic love of spectacular effects Burke proposes a different reading of the scene. Rather than beholding the assaults on the Queen with the cheering of a Yahoo, Burke finds in the scene "natural" and "melancholy sentiments" regarding "the unstable condition of mortal prosperity, and the tremendous uncertainty of human greatness." In the fall, he says, 
we learn great lessons; because in events like these our passions instruct our reason; because when kings are hurl'd from their thrones by the supreme Director of this great drama, and become the ubject of insult to the base, and of pity to the good, we behold such disasters in the moral, as we should behold a miracle in the physical order of things. We are alarmed into reflection; our minds (as it has long since been observed) are purified by terror and pity; our weak unthinking pride is humbled, under the dispensations of a mysterious wisdom. (p. 175)

Burke's ideal spectator here is one who feels pity, fear, and intellectual engagement, one who eschews the spectacle of frorol for its own sake, and educes from it a subtler, more delicat: sensibility. The ideal spectator would reclothe the naked body and soften the horror of the scene. He would provide "all the super-added ideas, furnished from the wardrobe of a moral imagination, which the heart owns, and the understanding ratifies, as necessary to cover the defects of our naked, shivering nature, and to raise it to dignity in our estimation . ." (p. 171). Burke's conservative response to the Revolution argues a restrained reclothing of the afflicted body over the Gothic indulgence of the naked one. The "aesthetic" theatre of the mind is evoked in preference to that other, intensely threatening aesthetic: the glorification of the vulnerable body made into a theatre-piece. 
Burke's vision of the Gothic theatre as the model for Jacobin conduct, and his return to delicate sentiment as its corrective, are criticized by his adversary, Thomas Paine. In his response to Burke's Reflections, Paine's 1791-2 Rights of Man demystifies Burke's interpretation of the events of the Revolution. One of those interpretations is the theatre of violence as Burke ciepicts it. For Paine, Burke's Reflections is itself nothing more than "a dramatic performance, and he must, I think, have considered it in the same light himself, by the political liberties he has taken of omitting some facts, distorting others, and making the whole machinery bend to produce a stage effect" (p. 59). Burke had accused his enemy of producing a stage effect which would cause the spectator to forget the real victim, but Burke himself, Paine charges, has produced the same show, 27 only the problem is that Burke assumes the natural response to be sympathy with the aristocrat. The tears which Burke would educe by his classical representation of Louis and Marie Antoinette affect him, in Paine's words, "not - . by the reality of distress touching his heart, but by the showy resemblance of it striking his imagination. He pities the plumage, and forgets the dying bird" (p. 51). By Burke's reasoning, argues Paine, we would end up pitying othello for his downfall, rather than condemning him for murder. In other words, Paine uses against Burke that conservative disdain for a theatre which promotes sympathy for criminals; the only difference is 
that, for Paine, it is the aristocrat, and not the revolutionary, who is the criminal.

From such admonishment Paine concludes, "Mr. Burke should recollect that he is writing History, and not Plays; and that his readers will expect the truth, and not the spouting rant of hightoned exclamation" (p. 50, emphasis original). To write History, for Paine, means not to order events according to rules of classical decorum and neoclassical sentiment, but to show everything as it is, with a realism that underlies a Jacobin novel like Godwin's Caleb Will writes:

It is to be observed throughout Mr. Burke's book, that he never speaks of plots against the Revolution; and it is from those plots that all the mischiefs have arisen. It suits his purpose to exhibit the consequences without their causes. It is one of the arts of the drama to do so. If the crimes of men were exhibited with their sufferings, stage effect would sometimes be lost, and the audience would be inclined to approve where it was intended they should commiserate. (p. 60 , emphasis original)

Although Paine continues a strain of antitheatricality here, he himself draws on spectacle for rhetorical strategy: atrocities and tyrannies, he argues, should be exhibited. The drama of the French Revolution is to be staged in its entirety if it is to be staged at all. Fnd such exhibition would do two things: first, 
it would destroy the "stage effect" of Burke's delicate sentiment (pity and fear for the tragic hero) by stripping away the false feeling we should have for the king and Queen of France. And second, such display would exploit the spectacle of suffering to demonstrate who is the victim in the drama and who is the villain. Whereas Burke advocated clothing the body in order to minimize the potential for sympathy for the commoner, Paine advocates its display. Despite his suspicion of theatre, Paine does not argue for the destruction of theatrical representation here (as had Rousseau) so much as he advocates the representation of everything, of both the causes and effects of tyranny. The truth of politics depends upon presenting crimes and their attendant pains, and by reading the bodies that Burke would have shrouded in decorum.

This representational theatre, furthermore, is made analogous to representational or representative government. Representational government, says Paine,

possesses a perpetual stamina, as well of body as of mind, and presents itself on the open theatre of the world in a fair and manly manner. Whatever are its excellences and defects, they are visible to all. It exists not by fraud and mystery; it deals not in cant and sophistry; but inspires a language, that, passing from heart to heart, is felt and understood. (p. 182) Paine's desire for an open theatre harks back to the great directors of the French Revolution itself. As Joseph Butwin 
notes, Maximilien Robespierre attempted to stage the National Assembly in a theatre, which required finding a space large enough to accommodate "the entire nation"." Butwin quotes Robespierre:

"A vast and majestic edifice, open to 12,000 spectators, should be the meeting place of the legislature. Under the eyes \{sous les yeux \} of so many witnesses neither corruption, intrigue nor perfidy would dare show itself; the genera\} will \{la voolonté generale\} would then be consulted, the voice of reason and the public interest would then be heard." ( $p$. $1 4 5 \longdiv { 2 0 }$

In Burke's theatre and politics, representation should be veiled, selective, and discrete; by avoiding excessive, uncontrollable emotion and gratuitous spectacles of pain, it should affirm human sentiment and pity for the fallen. In Paine's production of history, on the other hand, everything must be brought on stage. Politics, like theatre, is comprised of excessive, tyrannical powers. The only way to combat these powers is to see them, and to commit them to the public gaze.

To see or not to see: that is the question that underlies Romantic drama, both in the political representation of the French Revolution and in the playwrights' designs for drama. In the dialogue between Burke and Paine, we see the tension which Byron, coleridge, and shelley will inscribe in their writings about their plays. On the one hand, their "aesthetic" 
sensibilities demanded that they avoid Gothic excess, that the ideal and the delicate, the intellectual and the mental be cast in the principal role, one which upstages the horror of political tyranny and violent physical pain. But on the other hand, the dedication to a Painite, Jacobin vision of things as they are--a dedication to representing the politically downtrodden by representing the condemnably tyrannical--constantly tempted Romantic playwrights to stage their violence, and to explore the politics of this spectacle. To return to shelley's The Cenci for a moment, we find that the original story of the cenci tragedy was wrapped up in secrecy. "The Papal guvernment," writes shelley, "formerly took the most extraordinary precautions against the publicity of facts which offer so tragical a demonstration of its own wickedness and weakness; so that the communication of the MS. had become, until very lately, a matter of some difficulty."29 Here the Catholic Church (itself a rep esentative of theatre and theatrical imposture) hides the facts of the story in a cover-up which implicates it in an act of tyranny. Through the imposture of its own self-dramatization as innocent, the Church commits another imposture, that of hiding the "true story" of Beatrice's sufferings and crimes, a story which shelley wants to uncover, expose, and represent on stage. Given this ambivalence, I want to argue that in Byron's Marino Faliero, Coleridge's osorio (and its later version, Remorse), and Shelley's The Cenci, we are faced with a problem: while the playwrights preferred the sentiment: of Burke's disembodied, 
aesthetic drama, their political allegiance to Paine's representational government continually drew them toward the presentation of the aesthetic in its physical, empirical sense. Burke's and Paine's aesthetics reflect Burke's and Paine's politics, and their political differences centre on the distinctions in the meaning of the "aesthetic": Burke's aesthetic is a disembodied intellectualism, wsile Paine's is a political materialism. And so, Romantic playwrights must grapple with a mode of representation that avoids the Gothic excess of bodily immediacy, yet also avoids the conservative Burkean distortjons of the real.

\section{I I}

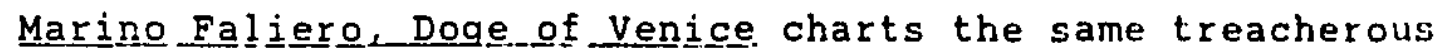
landscape that Byron himself was always trying to traverse--the landscape of aristocratic privilege and the subversion of that privilege. Written in 1820, published in 1821, and produced at. Drury Lane that same year (despite Byron's wishes to the contrary $3^{\circ}$ ), Marino Fali iero concerns the Doge, himself a member of the ruling class, conspiring against the ruling class for freedom. Faliero is outraged by Michael steno, a naughty nobleman who has carved on the ducal throne some lascivious wisecrack (which we never get to hear) about the Doge's wife. steno is reprimanded by the senate, who sentence him to one month under house arrest. Faliero, who had hoped for the death penalty, quickly transfers his rage for steno onto the senate who have allowed him and his wife to be "tainted by the accusing 
breath/ of calumny and scorn" without proper retribution (I,i,189-190). Faliero joins with Israel Bertuccio and a band of plebeian rebels to massacre the senate, but the plot fails when Bertram, one of the band, weakens in his resolve and warns a Senatorial friend to flee for his life. The band is captured, the plebeians are executed in full view of the assembled crowd, and Faliero is decapitated in a private execution. Thus, in this play Byron presents the failure of a revolution, and explores the possible reasons for that failure with the ambivalence of an aristocrat advocating republican empowerment.

Integral to this revolutionary failure is the inevitable inflicting of pain and murder, and the construction of a Gothic spectacle. When Faliero commits himself to the revolution, he is willing to destroy the amorphous body of Senators, to "strike, and suddenly,/ Full to the Hydra's heart" (III,ii,237-238). However, when theory becomes practice and he must imagine the attack on individual bodies, he expresses a reluctance to see the bloody business through:

All these men were my friends: I loved them, they Requited honourably my regards;

We served and fought; we smiled and wept in concert;

We revell'd or we sorrow'd side by side:

We made alliances of blood and marriage;

We grew in years and honours fairly,--till

Their own desire, not my ambition, made Them choose me for their prince, and then farewell! 
Farewell all social memory! all thoughts

In common! (III, $i$ i, 319-328)

Faliero, the man who would not be doge, cannot fully shake off his allegiances to his former aristocratic circle, even though they have shaken theirs to him. His response to the thoughts of revolution is, as Burke would have it, to move from an abstract political vision to a personal, individual pity: Faliero is alarmed into reflection by the imagined physical suffering of his old friends. He asks, "can I see them dabbled o'er with blood?/ Each stab to them will seem my suicide" (III,ii,471-472). As Carl Woodring has argued, Faliero is a man of feeling, not of action, and therein lies his tragedy.31 Faliero prepares to inflict pain and suffering, but is plagued by aristocratic, sentimental vestiges of his past.

spectacular pain, such as the revolution will produce, generates in the erstwhile aristocrat those humane sentiments of which Burke was so enamored. However, as Burke suggests, these sentiments need not--and must not--be the sole property of the old order (although that order naturally has them by heredity), but must also be the moral guardian of the plebian, or the sansculotte. The democratizing of this sentiment is embodied in the play by Bertram. Bertram is the sympathetic soldier, the man of sensibility for whom the spectacle of pain is intense and moving. In Bert:am, says Calendaro, There is a hesitating softness, fatal To enterprise like ours; I've seen that man 
Weep like an infant o'er the misery

of others, heedless of his own, though greater;

And in a recent quarrel I beheld him

Turn sick at the sight cf blood, although a villain's.

$$
\text { (II, i i, 68-73) }
$$

By his own admission, Bertram has "not/ Yet learn'd to think of indiscriminate murder/ Without some sense of shuddering; and the sight/ of blood which spouts through hoary scalps is not/ To me a thing of triumph. . ." (III,ii,64-68). In a way, Bertram is a study in Romantic heroism and sensitive pacifism; like Faliero, and Byron's Sardanapalus, he refuses to inflict pain where it is unnecessary, or to indulge in horror for its own sake. And like Faliero, Bertram too is the sympathetic spectator as defined by Burke, the spectator for whom the spectacle of pain leacis to a contemplation of the tragedy of human greatness and the fragility of life. In Bertram, then, Byron enfranchises the lower classes with a Burkean reverence for authority, order, and the dignity of the private human body, but by doing so, Byron also plants the seed for the revolution's failure.

Bertram's dilemma is similar to Faliero's in that both men are troubled by sympathy for the individual bodies they intend to destroy. But while this sympathy is the undoing of the revolution (because it makes Bertram a stool pigeon), it is also the central force that empowers the lower-class rebels and, paradoxically, furthers the revolutionary cause. This empowerment comes through Byron's treatment of the debate waged 
by Burke and Paine over victimization in the Revolution. When Burke had argued that the spectacle of suffering, if tastefully presented, would induce a moral sympathy from his audience, he had in mind the particular sufferings of Louis XVI and Marie Antoinette. In so doing, Burke cast the oppressors in the role of the oppressed. But if to see is to sympathize with the victim of oppression, then any victim whose pain is made visible is potentially worthy of sympathy. This is an important point for Paine's attack on the Reflections, and provides the means by which Byron moves sympathy from the Burkean aristocracy to the Painite commoner. Fe'iero's sensibility makes him not only the ideal conservative aristocrat, but, as Israel Bertucci describes, the ideal rebel:

[Faliero is] so full of human passions, That if once stirr'd and baffled, as he has been Upon the tenderest points, there is no Fury In Grecian story like to that which wrings His vitals with her burning hands, till he Grows capable of all things for revenge; And add to, that his mind is liberal, He sees and feels the people are oppress'd And shares their sufferings. (II,ii,168-176, emphasis added)

Faliero will be a revolutionary because the spectacle of suffering makes him sympathize with the oppressed--and in Venice, the oppressed is not the senate, but the commoner. What Byron 
picks up on here is the flaw in Burke's logic that opened up the space for rebellious sentiment: any kind of tragedy is capable of inspiring pity, and so it is difficult to regulate how and to whom the spectator will respond.32 Faliero is a tragic hero in Liat he recognizes his allegiance to an old order which must pass away, but he is a revolutionary hero in his willingness to die while destroying that order.

In an attempt to reduce the possibility of sympathizing with the wrong person, Burke rar Gothic spectacle--and its depictions of violence against criminals--off the stage; he reclothed the vulnerable, naked body in decorous draperies, and held it at a distance from revolutionary violence. Gory spectacle, he wrote, was to be rejected on the modern as it was on the classical stage (p. 176$)$, and "personated tyrants" demanding sympathy were to be censored. In Byron's positioning within the debate over what can and cannot be shown, such censorship is itself shown to be a form of tyranny. The Senate, like Burke, express a panic by their attempt to keep Faliero's execution out of the public eye and away from the public ear. It has ordered the execution of the plebejans to take place "upon the balcony/. . . in the place of judgment, / To the full view of the assembled people!" (V,i,9297). Bodies are put on public display, but not without precautions: Benintende, the Chief of the Ten, decrees, "lest they should essay/ To stir up the distracted multitude--/ Guards! let their mouths be gagg'd even in the act/ of execution" $(v, i, 100-103)$. As Jerome Christensen argues, "Faliero is tried 
and executed within the palace, where there is no possibility that his words or demeanour could incite the volatile populace - . ."33 Similarly, as Faliero is led away to the chopping block, he is warned, "Think not to speak unto the people; they/ Are now by thousands swarming at the gates, / But these are closed" ( $V, i, 549-552)$. Like Burke, the Senate recognizes the dangers inherent in publicizing one's pain, and like Burke, it does all in its power to keep suffering off-stage.

That Faliero should be executed "in private" indicates forcefully the senate's tyrannical hold on the city. For Byron, as for Thomas Paine, political tyranny is defined by what goes; on off-stage, outside the view of the public. He creates this feeling through an accretion of images of privacy. As the play op zns, Faliero is waiting for some indication of the senate's decision on Steno's sentence, but none can be had: "you know," says Vincenzo, "The secret custom of the courts of Venice" (I,ii,24-25). This "secret custom" surrounds the senate, whose dealings are never made known to the public, and in which the public has never had input. Byron's condemnation of this secrecy is made even more evident in The Two Foscari, where "The Ten"-the select, executive group of government--performs with such discretion that one of the senators crmplains: "the secrets/ of yon terrific chambers are as hidden/ From us, the premier nobles of the state,/ As from the people"; "men know as little/ of the state's real acts," says the senator, "as one of the grave's/ Unfathom'd mysteries."31 This secrecy is akin to what Foucault 
describes as a "gentle way of punishment" in the eighteenth century, in which tis forms of intimidation moved out of the public gaze (that is, away from the spectacle of the scaffold) and behind the threatening closed doors of private punitive spaces.3s Like Paine, for whom a representative government had the responsibility of exposing its acts to the public for accountability, Byron condemns the aristocratic conservative tendency to conduct its business in secret. The play exposes the secrets of government to public view, and reclaims a Painite openness for the political theatre of Venice.

This senatorial secrecy, however, is more than just an obvious tactic of deviousness. For Foucault, moving punishment behind closed doors was an effective means of public regulation not because of the way secrecy allowed the ill-treatment of bodies in prisons and asylums, but because it made the public at large wonder what really went on in these places. In short, the "gentle way of punishment" transferred the site of regulation from the body to the imagination. That very site which, for Burke, was capable of feeling all the pangs of fallen grandeur was also the faculty most prone to easy and insidious ideological manipulation. Given this paradoxical function of the sensitive imagination, Byron's reclamation of the public gaze appears to be more than simply an expression of allegiance to paine and Robespierre's "open theatre" of politics. He is as well reclaiming the epistemological assumptions that open theatre 
makes. When Faliero is checked on his periodic sympathies for the soon-to-be-murdered aristocrats, he explains,

It was ever thus

With me; the agitation came

In the first glimmerings of a purpose, when

Passion had too much room to sway; but in

The hour of action I have stood as calm

As the dead who lay around me.... (IV,ii,93-98)

The further he is from the spectacle of pain the weaker he is in his resolve. The imagination, that space associated both with Burke's theatre and with aristocratic tyranny, is in Faliero the source of doubt and wearriess--the source of the sentimental tears one would shed for the tyrant. But to get the revolution under way, one must be strong, stoic, ready for the spectacle of pial, and not weakened by it.

In the final scene of the play, the political power invested in spectacality--what Foucault reifies as "the gaze"--is wrested from the Senatorial tyrants and given to the Painite revolutionaries. Whereas the aristocrats hitherto had paralyzed the city by their "spies, the eyes/ of the patricians dubious of their slaves" (III,ii,234-235), they now accede to the public "gazers" who, Faliero brags, will crowd around his tomb to read his epitaph. But before they get to reading gravestones, they are far more interested in the execution. I indicated earlier that Faliero's execution occurs off-stage in order not to incite public feeling. But it isn't quite that simple. The stage 
direction for the final scene of Marino Faliero shows us "people in crowds gathered round the grated gates of the Ducal ralace, which are shut" ( $v, i v)$. They have come to get a glimpse of the suffering, or to "hear at least, since sight/ Is thus prohibited unto the people" ( $v, i v, 4-5)$, or perchance even to "catch the sound" (, iv, 14)--of what we aren't told, but presumably the axe. At one level, this is probabiy Byron's critique of the Gothic audience and its taste for spectacle. Like theatrical spectators straining their necks to catch a full view, the townspeople await--and even hope--for violence. But at another level, this prurience is not for its own sake. As one spectator reports seeing the deed done, the entire spectacle takes on a political directive:

Third.cit. Then they have murder'd him who would have freed us.

Fourth_cit. He was a kind man to the commons ever. Fifth cit. wisely they did to keep their portals barr'd. Would we had known the work they were preparing Ere we were summon'd here--we would have brought Weapons, and forced them! (V, iv, 20-23)

Despite the Senate's best attempts to hide the murder, despite their best attempts to keep the violence off-stage, the spectacle is given to a public which, when made aware of the senate's business, indicates its harsh disapproval of it. As the curtain lowers, Byron destabilizes senatorial power by using spectacality to engage public anger. The plebian masses here are given an 
open view of aristocratic tyranny, and they vow to fight that tyranny. We are left with a vision of the open theatre of politics, one which empowers the republican cause.

But the presentation of public power here is, at best, ambivalent. I began my discussion of Byron by noting that his political landscape was always one made treacherous by mixed allegiances.36 And so it is here. Byron's revolutionaries have seen it all, but they have seen it too late. They can only speak in the conditional tense of what they would have done, had they seen this execution in time. The power which is granted them by the spectacle of violence is, at the same time, rendered impotent by the senate which committed the violence.37 Moreover, this is only one of a series of degradations of the entire rebellion. After all, Marino Faliero's noble revolutionary sentiments art often upstaged by his petulant desire to avenge a slight to his pride. His entire place in the revolution begins in response to a schoolboy prank against his wife Angelina who has long since forgotten the matter, leaving steno's punishment to be his own loss of respect resulting from the insult. And finally, the text. gives us numerous examples of the generosity and benevolence of the aristocrats (indeed, their crime against Faliero is that of being too kind to steno). The revolution may have failed, but it also may not have been worth fighting in the first place.

The ambiguity which underlies the commoners' spectatorship at the end of the play is also, to some degree, ours as readers and members of an audience. Even though the crowd is given the 
spectacle--the very staging of which carries potentially enormous political weight--the theatre audience is not. In the printed text--perhaps the only representation Byron wanted us to see--we see the power of the open theatre being tentatively affirmed in the service of revolution. But at the level of stage spectacle, we are made acutely aware that this open theatre, in which all is seen, is not ours. We merely watch the crowd watching the violence. If seeing empowers the revolution, even minimally, then it is significant that we do not get to see. Byron seems to want us not to sympathize wholeheartedly with the revolution. Spectacality often awakens a political energy, but that energy can be misplaced or, like Wordsworth's in the previous chapter, "still-born," unable to be productive. Political theatre has its boundaries, ones which seem not to go beyond the wings of the Byronic stage.

\section{IV}

The ambivalence that Byron explores in his representation of open theatre is presented more fully by Samuel Taylor Coleridge. Although Coleridge's 오으응 does not deal directly with the French Revolution, its subject matter is still both intensely political and theatrical.38 The play is set during the "reign of Philip II, just at the close of the civil wars against the Moors, and during the heat of the persecution against them . . . "39 The titular character represents the tyrannical nature of this persecution, both in his public and in his private life. In the public world, he is responsible for the murder of the Moresco 
Ferdinand. Privately, he entertains a fanatical love for Maria, the betrothed of his supposedly dead brother Albert. When Maria refuses his advances, he stages a seance to recall Albert's spirit and thereby to prove that Albert is dead. The seance is unsuccessful because the sorcerer enlisted to perform it is Albert himself, dressed as a Moresco and in hiding, trying to determine whether a) Osorio was responsible for his "murder," and b) Maria has been unfaithful to him by marrying osorio. (The former is true, the latter is not.) When the seance collapses, Osorio suspects Ferdinand of treacherous interference and kills him, thereby bringing together his private and his political tyrannies. Although Albert and osorio are finally reunited-Osorio begging his brother's forgiveness--Osorio's tyranny has set the stage for his own disaster. Alhadra, Ferdinand's widow, enlists a band of renegade Morescoes to avenge her dead husband by slaying the Christian tyrant who murdered him. Thus, the play registers the concern with the sources and motives of political revolution, a concern still very much alive for coleridge as he wrote osorio in 1797.10

Coleridge's treatment of radical politics in this play centers most clearly on the character of Alhadra. The obvious revolutionary force in the playil, Alhadra, a Spanish Moor, has been cruelly imprisoned by the Christian church (in the guise of the Dominican Inquisitor Francesco, but represented also by osorio). She described the racially motivated suffering she has undergone: 
They cast me, then a young and nursing mother, Into a dungeon of their prison house. There was no bed, no fire, no ray of light, No touch, no sound of comfort! The black air, It was a toil to breathe it! I have seen The gaoler's lamp, the moment he enter'd, How the flame sunk at once down to the socket. o mise: able, by the lamp to see My infant quarrelling with the coarse hard bread Brought daily . . . (I,208-217)

As a result of this imprisonment, Alhadra wants revenge: "To have leapt upon [Francesco] with a Tyger's plunge/ And hurl'd him down the ragged precipice,/ 0-- it had been most sweet!" (I, 196198). Moreover, like a true Jacobin, she perfidiously attempts to incite Maria to similar acts of revenge: "Know you not/ What Nature makes you mourn, she bids you heal?/ Great evils ask great passions to redress them. . ." (I, 229-231). At this point in the play, Alhadra commands our sympathy. She is the innocent victim of the play, the object of tyrannical abuses of power. In her Coleridge gives voice to the last vestiges of Jacobin sympathy of which he was capable in 1797.

Alhadra's prison, without light, sound, or human contact, is like the prisons and state institutions of Byron's history plays: it exercises its tyranny in secret, outside the public view. This secrecy, furthermore, characterizes the climactic act of violence and tyranny in the play, Osorio's murder of Ferdinand. 
Osorio lures the Moor to a dark, isolated cave, one that has a chasm which "never thirsty pilgrim blest, which never/ A living thing came near" (IV,45-46). They fight, and osorio throws him into the chasm, remarking how the secrecy of the place enables him to murder: "Now--this was luck! No bloodstains, no dead body!" (IV,150). Like Byron's senate, and like the tyrant in Paine's vision of the French Revolution, Osorio acts in secrecy here, capitalizing on the lack of public spectacle that might otherwise testify against him. Once again, secrecy promotes tyranny.

Osorio's faith in his good luck, however, is unjustified: he is seen. Alhadra, who first watchei" Ferdinand enter "the mouth of yonder cavern," then "saw the son of Velez [that is, osorio]/ Rush by with a flaring torch; he likewise entered" (IV,387-389). After Osorio leaves, she says, "I crept into the cavern" and "I look'd far down the pit":

My sight was bounded by a jutting fragment, And it was stain'd with blood! Then first I shriek'd! My eyeballs burnt! my brain glew hot as fire!

And all the hanging drops of the wet roof

Turn'd into blood. I saw them turn to blood!

And I was leaping wildly down the chasm

When on the further brink I saw his sword,

And it said, Vengeance! (IV,414-422)

Here, Osorio's tyranny has left just enough telltale signs to inform Alhadra of what has happened. The landscape marked in 
blood, combined with Ferdinand's dying groan, provide enough sensual stimulus for her imagination to complete the picture, and she determines to be avenged. Despite Osorio's best attempts to keep the murder secret, it is exposed to public view--both through what Alhadra has seen, and through what she then tells her fellow revolutionaries. Tyranny, albeit equated with secrecy, is wrenched into the public view.

When Alhadra sees the bloody precipice on which her husband died, she wants a revenge which itself taikes the form of public demonstration. As the representative of Coleridge's Jacobin sympathies, she wants to expose tyranny to public accountability. For example, when Francesco is finally apprehended for his persecution of the Morescoes, he is dragged into the centre of the crowd. Here his case is debated between two Moors: Maurice, acting as defense attorney, and a more blood-thirsty old man acting as prosecutor. Both of these men address their cases to the Moresco band, and to the penetrating eye of Alhadra. "Here!," Francesco is told as Alhadra looks on, "in her presence --" $(V, 70)$ he will probably be given the death penalty. He is only saved from murder by the fact that Alhadra is waiting for a bigger, more grandiose spectacle, the execution of Osorio: "none shall die" she declares, "Till I have seen his blood!" (V,97-99). And it is this que: - blood, this desire to expose Osorio's guilt, that constitutes the final act of the play, in which Osorio is killed. Revolutionary action here is conducted within a public forum where $e$ hing is open to be seen. To the 
degree that the play engages a revolutionary sympathy, one which Coleridge shared in the early 1790s, it demonstrates that public accountability and justice depend on what Paine called the "open" representation of things as they have happened.

However, Alhadra's call to see Osorio's blood borders on an excessive, hyperbolic passion, one which coleridge, with his own antijacobin ambivalence, clearly wants his audience to resist. In order to assist in that resistance, Coleridge does not indulge the violent srectacle which Alhadra had imagined. At the play's close, Alhadra orders that Osorio be led away from the delicate Maria to be murdered, because "b:hy should this innocent maid/ Behold the ugliness of death?" (V,301-302). Osorio is escorted off-stage, where he will be murdered and Ferdinand avenged. And like Maria, we are not given a chance to be repulsed by the graphic, Gothic spectacality that Burke so abhorred. Instead, Alhadra is given the last word, which is a word on justice:

I thank thee, Heaven! thou hast ordain'd it wisely, That still extremes bring their own cure. That point In misery which makes the oppressed man

Regardless of his own life, makes him too Lord of the oppressor's. Knew I an hundred men Despairing, but not palsied by despair, This arm should shake the kingdoms of the world; The deep foundations of iniquity should sink away, earth groaning from beneath them; The strong holds of the cruel men should fall, 
Their temples and their mountainous towers should fall;

Till desolation seem'd a beautiful thing,

And all that were and had the spirit of life

Sang a new song to him who had gone forth

Conquering and still to conquer. (V, 307-320)

Coleridge's hopes for the revolution, like Byron's, are dubious at best: miserable, despairing people become so unconcerned for their own lives that they have nothing to lose by rising up against their oppressors. Yet, there is some revolutionary hope here: the spirit of life goes forth and sings a new song, rising out of the ashes of a desolate and despairing world. And what hope there may be in transforming the desolate into the beautiful is embodied in Maria. It is she who was spared the spectacle of misery and violence; it is she who remains untainted by murder"s rhetorical effects. The play does allow the possibility of a new world order, as long as it is based on innocence as well as justice.

What seems clear from this treatment of the Jacobin cause is the playwright's marked restraint in depicting the spectacle of suffering. While Alhadra--and presumably, any Jacobins in the audience-wanted to see osorio's blood, and have it be seen as part of the poetic justice due the tyrant, Coleridge withdraws the privilege. He does not allow the radicals in his audience to feast upon Osorio's tyrannic blood. Nor, however, does he allow the spectacle of a blond-bath to sully his revolutionaries, and to open them up to a conservative condemnation of barbarity. 
Rather, Coleridge avoids dramatizing the ghastly punishment inflicted on osorio so that we will maintain the proper response (here, a response of Burkean sympathy) for Alhadra and her cause. Despite the Painite sympathies which the play espouses, Coleridge adheres to $a$ Burkean theatrical sentiment, one which keeps Jacobin violence and Gothic excess off-stage. And the result is the kind of restrained, intellectual theatre wh: ch the Romantics so strongly wanted to espouse.

This restraining of the tendencies of Gothic spectacle works with another character as well: Albert. Like Alhadra, Alhert too is a victim in the play, but unlike the Moresco Mohammedan, Albert is a white Christian, a symbol of aristocratic goodness and order. Thus, it is not surprising that while Alhadra wants blood publiciy to flow, Albert wants to induce a more internal, non-violent revolution in the conscience of Osorio.12 In disguise, Albert recounts to Maria and Alhadra a dream in which he had been given over by a "friend" and an "idolized maid" for assassination. Having escaped, he sought no revenge, but rather "Pray'd that Remorse might fasten on their hearts,/ And cling, with poisonous tooth, inextricable/ As the gor'd lion's bite!" (I,319-321). As Carl Woodring has argued, Albert counters Alhadra in that he represents the play's private, metaphysical purpos:-the internal sentiment of remorse as a revolutionary force-over the more public, Jacobin issue of the opposition to tyran.ly.43 The trajectory from Alhadra to Albert, like that from Paine to Burke, reprosents the trajectory from where Coleridge 
had reen, as a Jacobin, to where Coleridge was going as a Christian and a metaphysician: toward an interest in the revolution of the mind.14

I would like to suggest here that coleridge's purpose in his depiction of Albert is not only co counter a materialist political revolution with a metaphysics of sentiment, but also to point to an ambiguity in the revolutionary possibilities of Gothic spectrit. This ambiguity occurs through coleridge's contradictory lepresentation of Albert. While Albert is the Burkean propounder of sentiment, he is also the Gothic dramatist par excellencs He hopes to induce the all-important remorse in osorio by means of a spectacle--a spectacle of suffering. For some reason--psychotherapy perhaps--Albert has painted a picture for his friend Maurice of his own assassination at the hands of osorio's henchmen. During the seance, Albert intends to conjure smoke, music, and theatrical paraphernalia, at the end of which he will expose the portrait as th "soul" of the decersed Albert. In so doing, he hopes to induce in Osario the guilt that will convert him:

That worst bad man shal' find

A picture which shall wake the hell within him, And rouse a fiery whirlwind in his conscience!

( I I , i , 323-325)

Now this is Gothic spectacle if ever there was one; this is exactly the kind of thing Burke hated: special effects, violence, excess, melodrama. Moreover, Albert conjures images of a "cold 
corse . . / with many a stab from many a murderer's poniard" (III, i,81-82), an image which greatly moves osorio prior to Albert's presenting of the portrait. Like Paine, Albert hopes to "uncover all concealed things" (III, $i, 9$ ) and, by use of Gothic spectacle, to expose tyranny and to bring the tyrant to account for himself. But unfortunately, Osorio is too stupified by all the Gothic stage business to notice the portrait at all. The spectacle fails miserably and with it, Paine's theatre of politics is turned upon itself: Gothic excess induces no change of heart, but rather is destroyed by its own gimmicks. As Coleridge explores the antirevolutionary aspect of inis play, he undermines both Jacobinism and the efficacies of Gothic theatre.

If Osorio registers Coleridge's political ambivalence in 1797, his later dramatic work is far more unambiguously conservative. In the few years preceding 1807 , wher a revisted Osorif was staged at Drury Lane as Remorse, Coleridge's antijacobin sentiments hardened into a firm Tory position, one which Coleridge advocated with a fierceress bordering on selfdelusion.43 Thus, there are significant changes to osorio in Coleridge's later dramatic offering, changes which reflect a more antijacobin agenda. Unlike Osorio, Remorse does not give the final word to the oppressed Jacobin rebel. Rather, Alhadra is eclipsed in the final scene by Alvar (Albert from osorio), who gives the closing speech. And rather than espousing a theory of political justice, as Alhadra had done, Alvar, like Albert before 
him, apostrophizes the conscience as the real site of political change :

In these strange dread events

Just heaven instructs us with an awful voice,

That Conscience rules us e'en against our choice.

our inward Monitoress to guide or warn,

If listered to; but if repelled with scorn,

At length as dire Remorse, she reappears,

Works in our guilty hopes, and selfish fears!

still bids, Remember! and still cries, Too late!

And while she scares us, goads us to our fate.46

Here we see the intellectual project of Coleridge and indeed all Romantic drama, despite its political allegiance-to make the theatre a site for mental drama, to make us think rather than see, to validate the conscience and the mind, rather than gory stage spectacle, as the real site of politics. The internalized, mental position which Albert advocated in Osorio, but which was countered by the play's sympathy for Alhadra, here metamorphoses into a peroration which implicitly condemns Gothic excesses, excesses that are identified with Jacobin ideology.

However, the ambivalence which spectacle produced in osorio shows up, under a different guise, in Remorse: the revision may be more Burkean in its politics, but conversely, it is more Painite in its spectacle. In this version, Ordonio (Osorio is the original) is killed on stage. Having just reconcilea inimself to his wronged brother Alvar and having proclaimed the 
everlasting majesty of conscience and remorse, ordonio is then murdered. This murder we are to see, and to see as senseless and unnecessary. Staging the murder, I would suggest, does two things: first. it pleases the crowd by catering to the very taste for stage-violence that Coleridge abhorred (and does so successfully: Remorse ran for twenty-eight nights and netted at least $£ 300$, whereas osorio was never produced); and second, it uses Paine's desire for spectacle to condemn Paine's own apostle. Alhadra. When Alhadra hustled the violence off-stage in osorjo, she not only prevented Maria from exposure to a horrific spectacle, but she (Alhadra) also made us less likely to condem her by giving us no direct image of her barbarity. By watching Alhadra commit violence in Remorse, we know we are to condemn her. At the end of the play, ordonio is plagued by everlasting remorse (and Coleridge knew what punishment that could be), and so he hardly needs further punitive measures. Alhadra's (and the play's) violence is gratuitous and therefore condemnable. Thus, the Burkean conservatism which more clearly underwrites this play damns Painite politics, but to do so it uses the very Gothic excesses which ii hates, and which Paire's theatre demands. Coleridge's treainent of the spectacle of violence here is ultimately a question of instruction: we see Alhadra committing violence in order that we may condemn her. In Foucault's terms, Alhadra's tyrannic action is submitted to the public gaze in order that such action can be diagnosed and evaluated. Moreover, the spectacality of violence here actually evokes a certain 
ideological allegiance: by seeing acts of violence, we are asked to align our sympathies with the victim of that violence--the victim in this case being osorio. Thus, Coleridge obscures the boundaries established by Paine and Burke. For Paine, as for Foucault, the lower classes are always the oppressed, the aristocracy always the oppressor; for Burke, it is the aristocracy which should command our sympathy. But while Paine and Burke have opposing views on who was the victim in the French Revolution, Coleridge is much more anxious about keeping distinct the categories of victim and tyrant. Coleridge's attempts at drama are attempts to align himself with one political theatrical-position, only to be plagued by the other (the Jacobin Osorio required Burkean restraint, whereas the Burkean Remorse. found it necessary to spectacalize violence). In Coleridge's use of the Painite, Gothic spectacle, there is a nostalgia for the clear political directives that come with that spertacle, directives that Paine cutlined in Rights of Mar.47 At the same time that the spectacle of violence is being ejected from the stage (squelched by Burke in the theatre of politics and by the Romantics in the politics of theatre), it is being desired as a form of political instruction. Violence is always pedagogical and, here, it is an unacknowledged legislator of the theatrical effect.

\section{v}

The unacknowledged legislation of violence and pain is perhaps most fully explored in that voice of literary idealisni, 
Percy Bysshe Shelley. If, as Shelley telis us in Prometheus. Unbound, "the deep truth is imageless,"48 so then is pain. The Cenci is about rape, parricide, and torture, all of which occur off-stage. As we have already seen, The Cenci was shelley's attempt to portray "the impartial development of such charactels as it is possible the persons represented really weit, togetlin: with the greatest degree of popular effect to be produced by such a development."19 This is to be a theatre of mimetic representation, not "a mirror which makes beautiful that which is distorted" (as is the function of poetry in "A Defence of Poetry"so), but rather a demonstration of the "perfect mirior of pure innocence/ . . [being]/ Shivered to dust" (V,iv,130132).31 But in that representational, mimetic theatre, shelley has to invoke the imagination so that poetry will "mitigate the pain" and teach the human heart a knowledge of itself. Shelley speaks of the private space of the imagination as the space where the effects of spectacular pain occur, but I want to argue that that site is more problematic than shelley's "Preface" allows. In shelley, the beautifying mirror and that which is shivered to dust are often rendered the same thing by the destructive agencies of pain and spectacle.

Like Byron and Coleridge, Shelley was aware of the ambiguities that the spectacle of pain could present for his viewers, and keeping pain off-stage was an attempt to minimize those ambiguities. While we are clearly meant to condemn the tyrant-father Francesco Cenci, 32 for examble, we are not so sure 
that we should want to kill him. In shelley's depiction, he is at least partially sympathetic. Olimpio and Marzio, his murderers, express this tenuous sympathy as they describe hovering over his deathbed, unable to kill him. Olimpio says,

We dare not kill an old and sleeping man;

His thin grey hair, his stern and reverent brow, His veined hands crossed on his heaving breast, And the calm, innocent sleep in which he lay, Quelled me. Indeed, indeed, I cannot do it...

(IV, i i , 9-13),

to which Marzio adds,

And now my knife

Touched the loose wrinkled throat, when the old man stirred in his sleep, and said, "God! hear, o, hear, A father's curse! What, art thou not our father?" And then he laughed. I knew it was the ghost of my dead father speaking through his lips, And could not kill him. (IV,iii,16-22)

Like Byron's Faliero and Bertram. Shelley's cutthroats find abstract tyranny easy to kill, but real bodies, especially paternal ones, are another matter. The sight of Cenci's Duncanlike vulnerability is enough to soften the resolve of the most hardened criminals, who become willing to spare Cenci, despite his villainy. This temporary reticence is intended to introduce to the spectators the possibility of a sympathy for Cenci, one which would be heightened to dangerous levels if his murder were 
to appear on stage. After all, if hardened criminals are hesitant to kill the body that lay before them, then how should a sensitive audience respond? Similarly, if we were to witness the rape and violent abuses perpetrated on Beatrice, our sympathy would increase with her markedly through the direct visual image of her suffering. We would react with the same incensed horror that motivated Burke in his account of the attack on the Queen. Thus, like Burke, might we fall prey to what shelley fears, "the restless and anatomizing casuistry with which men seek the justification of Beatrice. . . ."53 In Paine's open theatre, representations of violence demonstrated through clear cause and effect who was tyrant and who was victim. In shelley's theatre, representations of violence would obfuscate that distinction all the more.

Shelley's reluctance to stage the play's violence points not only :o a concern for dramaturgy and audience manipulation, but to a larger problem of the representation of tyranny in general. Like Burke, who also preferred the tasteful, discreet theatre, Shelley associates tyranny with the love of gratuitous violent spectacle. Early in the play, Cenci defines human nature thus:

All men delight in sensual luxury,

All men enjoy revenge; and most exalt

Over the tortures they can never feel--

Flattering their secret peace with others' pain. But I delight in nothing else. I love 
The sight of agony, and the sense of joy,

When this shall be another's, and that mine.

$$
(I, i, 77-83)^{54}
$$

If human nature loves to see agony in order to triumph over it, then the slight on lovers of the Gothic theatre could hardly have gone unfelt here. But tyranny is aot simply limited to sadistic (or Addisonian, for that matter) delight in seeing someone else suffer. Tyranny actually uses the public status of theatre to increase its own effects. Cenci is repeatedly represented as revelling in the public gaze: Cardinal Camillo tells him that the Pope is aware of the manifold and hidsuss "deeds/ Which you scarce hide from men's revolted eyes" ( $1, i, 13-14)$. Moreover, when Cenci wishes to announce the death of his sons Rocco and Christofano, he throws a banquet, invites his friends (?!) and kinsmen, provides entertainment, food, and raiment--in short, constructs an entire spectacle to make himself look carefree and benevolent--only to anrounce that he has murdered his own children. Cenci uses theatre to heighten the impact of his announcement, and thereby to increase the fear he induces in his family and guests. As he intimates later, theatrical spectacle increases publicity, and increased publicity means increased power over a world which is "Loud, light, suspicious, full of eyes and ears" (II,i,I79). Rather than avoiding the public gaze, as Paine had argued tyrants do, Cenci revels in it as a medium of power. And this desire for publicity is the final torture he can inflict upon Beatrice: 
I will drag her, step by step,

Through infamies unheard of among men:

She shall stand shelterless in the broad noon

of public scorn, for acts blazoned abroad....

(IV, $i, 80-83$ )

Cenci's power not only enjoys spectacle, but it actually proceeds from spectacle. In Shelley's depiction of tyranny, the

"imposture" I noted at the beginning of this chapter, cuts across both the political and the theatrical, as theatre itself becomes an ageni of abuse.

Yet, if Cenci's power depends upon publicity and theatre, so does it seem equally to depend upon privacy, secrecy, and silence. At the most obvious level, secrecy promotes tyranny as Cenci decides that the rape must take place in the remote castle of Petrella, as opposed to the public city of Rome. But this secrecy has empowered cenci all along. In the opening lines of the play, we see Cenci's power established by keeping his deeds off-stage: "That matter of the murder is hushed up," Cardinal Camillo tells him, "If you consent to yield his lioliness/ Your fief beyond the Pincian gate" ( $1, i, 1-3$, emphasis added). The last time "that matter" had been discussed, an architect in the employ of the Pope's bastara son had seen "the deed" and so cencj vows, "Henceforth, no witness--not the lamp--shall see/ That which the vassal threatened to divulge/ whose throat is now choled with dust for his reward" (I,i,21-23). Finally, as his guests rail over the announcement that the sons are dead, he 
counsels, "Beware! For my revenge/ Is as the sealed commission of a king/ That kills, and none dare name the murderer" (I,iii,96-98). This secrecy proceeds not only from a fear of the public gaze (from witnesses who might tell the Pope what the tyrant is doing, or "name the murderer"), but also from what Paine described as the medium of aristocratic tyranny: by not being exposed to public accountability, by not making a spectacle of himseif, the tyrant can exploit and fulfill his own desires at others' expense. Thus, while shelley on the one hand keeps violent excesses of stage, in the private, secret space of the imagination, he seems on the other to argue that secrecy and discretion are themselves agents of tyranny. In short, shelley attempts to expose how both secrecy and spectacle can contribute to barbarism and cruelty.

By rendering both spectacular violence and off-stage violence as endemic to the strategies of tyranny, shelley is actually addressing the site at which tyranny is most directiy understood: the spectator's imagination. Beforf Beatrice is raped, the beginnings of madness express themselves in her contemplation, in her imagining of Cenci's tyranny:

He comes;

The door is opening now; I see his face;

He frowns on others, but he smiles on me, Even as he did after the feast last night.

$$
\text { (II, ii, 18-21) }
$$

And moments later, Beatrice says, 
Oh! He has trampled me

Under his feet, and made the blood stream down

My pallid cheeks. And he has given us all

Ditch water, and the fever-stricken flesh

of buffaloes, and bade us eat or starve,

And we have eaten. - - He has made me look

On my beloved Bernardo, when the rust

of heavy chains has gangrened his sweet limbs,

And I have never yet despaired--but now. (II,ii,64-72)

None of this, of course, has really happened, and yet all of it has happened. It is a commonplace in criticism of the play thist Beatrice eventually becomes what her father cursed her to be, that her interral Eelf comes to imitate his tyranny.s3 By the logic of the play, the imagination joins with the body to experience degradaticn and tyranny. Beatrice's incipient madness here, that which will finally lead her to kill her father, is a product both of the pain of rape and of an imagination which becomes unable to recognize a difference between external stimulation and internal, imaginative constructions. Whether Beatrice actually saw Bernardo chained and gangrenous (which she didn't; Bernardo's is the only body in the play to remain unscarred) makes no difference to her experience of the horror she perceives in cenci. The impact of the play, and the tragedy it invokes, comes from shelley's depiction of the imagination as penetrable, rendable, corruptible. Whereas Burke had privileged the imagination over the degrading effects of spectacle, Shelley 
here actually makes spectacle an internal phenomenon: he depicts it as product of the active, sensitive imagination. Nothing exists but as it is perceived.56 In Romantic imaging, the distinction between the two is collapsed, and the infectious degradation of spectacle becomes imaginative and self-generated.

By breaking down the divisions between the imagination and spectacle, the play ultimately obscures the boundaries between privacy and publicity, between what we imagine ourselves to be and what others see us as being. Because of this obfuscation, Beatrice is unable to find a refuge from her affliction: she can retreat neither to a private world cut off from the tortures of the outside, nor to a communal sharing of her pains. Her health and sanity depend upon naming the crime of rape, of representing it publicly, to herself and others, in order to be able to control and understand it:

If I could find a word that might make known The crime of my destroyer; and that done My tongue should like a knife tear out the secret Which cankers my heart's core. . . (III,i,154-157) But to speak the crime, to make it a matter of public understanding outside th: zivacy of the self, is to make the experience of the crime even worse: "If I try to speak/ I shall go mad" (III, i, 84-85).37 Besides, she argues to Lucretia, "What are the words which you would have me speak?/ I, who can feign no image in my mind/ of that which has transformed me" (III,i,108109). Within the imagination is the need to represent the 
painful experience of violence-to feign an image in an act of theatre--and the inability to do so. For David Marshall, the theatricalization of the self in the eighteenth century was a way of hiding oneself from the gaze of the world at the same time as: meeting the demand to be on the stage of the world.5B For Beatrice, self-theatricalization is tantamount to selfannihilation, because to make the rape known is to destroy the self that experienced the violation; yet, at the same time, expression is necessary for distancing herself from pain, for giving her some framework to understand, process, and control it.s9 The private world and the world of spectacle are indivisible, and yet irreconcilable. While shelley's idealism asserts that the deep truth is imageless, The Cenci reminds us of another imagelessness: as Elaine Scarry has argued (and as I quoted earlier), pain and physical violation are also imageless, in that there is no language to express them, no image to represent and publicize thein. Without representation, pain destroys the salvific force of the imagination; it renders the two mutually constitutive and, like the "scorpions ringed with fire" (II,ii,70), mutually destructive.

In shelley, then, we find the clearest articulation of an anxiety that has been running through each of the plays I have discussed. Early in this chapter, I noted Mary Jacobus's point that the Romantics ran violence off the stage in order to consign it to the imagination where it could be controlled and worked upon. But while the imagination may be a private theatre, a 
place where the playwright might control the rhetorical implications of spectacular pain more fully, it is also feared as a potential space for the very violence it sought to control. Thomas Paine had written with a naive optimism that "It is the faculty of the human mind to become what it contemplates, and to act in unison with its object" (p. 109).60 Byron, Coleridge, and Shelley all contemplate a peaceful and just republic, even though the particular political structure for realizing that republic differs in each writer. But what they are each faced with is the possibility that violent revolution--itself a source of contemplation--may remain all too present in that republic, because it ultimately exists in the mind. For Byron, a revolution of the mind--that "mental drama" he so hoped for--was always plagued by self-delusion, by the possibility that a republic's liberation was never wholly desirable or controllable. For Coleridge, mental revolution could never be trusted to effect the kind of social control he thought was necessary: public displays of violence are still always necessary. And for Shelley, the mental revolution could never replace the public one, but rather only supplement it. Violence renders the salvific imagination itself a political stage, one whose vestiges of revolution frequently call upon the spectacle of violence to structure and define it. 
Notes

1.Percy Bysshe Shelley, "Dedication' to The Cenci", in shelley's Poetry and Prose, ed. Donald H. Reiman and Sharon B. Powers (Toronto: พ.พ. Norton and Co., 1977), PP. 237-8.

2."'Preface' to The Cenci," p. 239.

3. Percy Bysshe Shelley, The Complete Works of Percy Bysshe Shelley Vol. X, ed. Roger Ingpen (New York: Gordian Press, 1965), p. 151, emphasis original. Shelley so clearly envisioned this play as being performed that he wrote the principal part of Beatrice for the actress Eliza O'Neill. Not only was her style suited to the representation of Beatrice's passions, but her fame would help ensure the play's commercial success.

4. Ibid., p. 61 .

5. "Preface," p. 241.

6.Quoted in Oswald Doughty, Perturbed Spirit: The Life and Personality of Samuel Taylor Coleridge (Toronto: Associated University Presses, 1981), p. 123.

7.Samuel Taylor Coleridge, Letters of Samuel Taylor Coleridge Vol 1, ed. Ernest hartley Coleridge (London: William Heineman, 1895), p. 231 . 
8.Lord Byron, "Preface" to Marino Faliero, Doge of Venice, in Frederick Page and John Jump (eds.), Byron: Poetical Works (New York: Oxford University Press, 1987), p. 408. All further quotations from the play will be cited in parentheses in the text. 9.Letters, Vol. VIII, p. 186, emphasis original.

10. Byron served on the selection Comnittee for Drury Lane between 1815 and 1816, when he left England for Geneva. In that time he was inundated with Gothic theatre manuscripts which permanently soured his taste for the theatre. Ironically, the only one of his dramas to achieve any great stage success was Werner, which catered to the public taste for melodrama.

11. Earl Wasserman summarizes the history of explanations for the pleasure of tragedy, centering his essay on the question, "Why in the temple of pleasure do we erect the goddess of pain?" see "The Pleasure of Tragedy," ELH 14 (1947): pp. 283-307.

12. Matthew Gregory Lewis, The Castle Spectre (1798). (New York: Woodstock Books, 1990), p. 79.

13. Jonathan wordsworth, "Introduction to The Castle spectre (1798)." n.p.

14. For a discussion of Byron and Coleridge's dislike of the popular theatre, see John David Moore, "Coleridge and the "modern Jacobinical Drama': Osorio, Remorse, and the Development of Coleridge's Critique of the stage, 1797-1816" Bulletin ut 
Research in the Humanities 85 (1982): pp. 443-46i.

15. "Preface," p. 240.

16. Letters Vol. II, pp. 607-608.

17. Letters Vol. VIII, p. 218 .

18. The eighteenth century's suspicion of grand spectacle goes back at least as far as Diderot. As Michael Fried writes, - Diderot urged playwrights to give up contriving elaborate coups de théâtre (surprising turns of plot, reversals, revelations), whose effect he judged to be shallow and fleeting at best, and instead to seek what he called tableanu (visually satisfying, essentially silent, seemingly accidental groupings of figures), which, if nroperly managed he believed were capable of moving an audience to tise depths of its collective being. (Absorption and Theatricality: Painting and Beholder in the Age of Diderot [Berkeley: University of California Press, 1980], p. 78)

As shelley has already indicated, the point of this intense movement is to appeal to the audience's moral being. Mary Jacobus describes how, for Wordsworth, the theatre was threatening because it risked moving the audience too much, and too much excitement would impede the use of the imagination--a danger more likely in those "sickly German tragedies" which exploit so much graphic violence. See "'That Great stage'," pp. 
353-387. For a more general history of the problem, see Janet Ruth Heller, "The Bias Against Spectacle in Tragedy: The History of an Idea," The Eighteenth Century 22 (1982): pp. 239-255.

19. "Great Stage," p. 375.

20. "Dedication," p. 238 .

21.Jonas Barish, The Antitheatrical Prejudice (Los Angeles: University of California Press, 1981).

22. See Foucault, Discipline and Punish, p. 68 , and Paulson, Representations of Revolution.

23. Moore, p. 444 .

24. Samuel Taylor Coleridge, "The Friend II", The Collected Works of Samuel Tay lor Col er idge Vol. 4, ed. Barbara Rooke (Princeton: Princeton University Press, 1969), p. 220, emphasis original. Hoore also quotes this passage in his essay on coleridge and Jacobinical drama.

25. For a discussion of the Revolution as theatre, see Joseph Butwin, "The French Revolution as Theatrum Mundi," Research studies 43 (1975): pp. 141-152.

26. Jean-Jacques Rousseau, Letter to $M$. d Alembert on the Theatre, trans. Alan Bloom (Ithaca: Cornell University Press, 1968), p. 16. 
27. Paine too is drawing on an antitheatrical prejudice. And like Burke, Paine shares this prejudice with Rousseau. But this time, the prejudice is not just against theatre, but against the theatre of sentiment: "the heart," writes Rousseau, "is more readily touched by feigned ills than real ones, [and] theatrical imitations draw forth more tears than would the presence of objects imitated. . " (Letter, p. 25). For Rousseau, Paine and Burke, the problem with theatre is that imitations manipulate sentiments for immoral ends. Rousseau strongly objected to the eighteenth-century dramatic tendency (as in Racine) to make the villain sympathetic; such a ploy equates virtue with vice, and destroys the spectator's reason (p. 29).

28. Butwin is quoting Robespierre from Textes chroisis, ed. Jean Poperen, tome II (Paris: Editions Sociales, 1965), pp. 150-152. 29. "Preface", p. $239 n$.

30. On 12 January 1821, Byron wrote in his journal, "[John] Murray writes that they want to act the Tragedy of Marino Faliero;--more fools they, it was written for the closet. I have protested against this piece of usurpation (which, it seems, is legal for managers over any printed work, against the author's will) and I hope they will not attempt it" (Marchand, Letters VIII, pI. 2223). A month later, on 16 February, he wrote to John Murray and repeated the request.

There is a whole debate regarding Byron's intentions regarding the staging of the play, a debate to which I do not 
wish to contribute. For the classic outline of Byron's ambivalence regarding the theatre, see David Erdman, "Byron's Stage Fright: The History of His Ambition and Fear of Writing for the stage," ELH 41 (1939): PP. 219-243.

31. Politics.of English Romantic Poetry, p. 183.

32. David Marshall has identified this fear in Diderot as a fear of sympathy as contagion (Surprising Effects, pp. 91-99). But while Marshall discusses this phenomenon in terms of constructions of self and other, Byron's fear has a very real political element, one of partisan sympathies.

33. Jerome Christensen, "Marino Faliero and the Fault of Byron's Satire," Studies jin Romanticism 24 (1985), f.320.

34. Lord Byron, The Two Foscari in Complete Works, I,178-181 and $184-186$

35. Foucault, Discipline_and Punish, pp. 104-131.

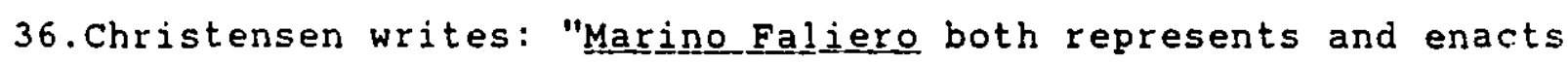
Byron's ambivalence about his own social status and about the possibility for effective political action in contemporary England" ("Fault of Satire," p. 321).

37. For Daniel P. Watkins, this ambivalence represents Byron's wish to "[plunge] beneath surface considerations such as episode and spectacle in an attempt to develop a coherent imaginative portrayal" of the "unifying principles" of political life 
(Watkins, "Byron and the Poetics of Revolution," Keats-Shelley Journal. 34 [1985], p. 104). But such ambivalence also makes a political statement of its own. What we see is an image of a peasant rebelition as somewhat prurient, slow, bombastic, and ineffectual.

38. For discussions of this question, see John David Moore, and Daniel P. Watkins, "In That New World': The Deep Historical structure of Coleridge's osorgio," Phil 으의ical Quarterly 69 (1990): pp. 495-515.

39. Samuel Taylor Coleridge, Osorio, in Ernest Hartley Coleridge (ed.), The Complete Poetical Works of Samuel Taylor Coleridge Vol. I (Oxford: Clarendon Press, 1957), p. 519. All further references to the play will occur in parentheses in the text. 40. Watkins, "In that New World"," p. 495. See also Elizabeth Sewell, "Coleridge on Revolution," Studies in Romanticism 11 (1972): pp. 342-359.

41. Moore, p. 453.

42. For a more complete discussion of the class determinants in the depictions of Alhadra and Albert, see Watkins, "Deep structure".

43. Carl woodring, Politics in the Poetry of Coleridge (Madison: University of Wisconsin Press, 1961), p. 204. 
44. After 1800, Coleridge focussed almost solely on a definition of politics and revolution as occurring internally, in the imagination, a definition which he explores more fully in the Biographia Literaria. For a discussion of this move and its implications for politics, see the group of essays "Coleridge: The Poljtics of the Imagination," ed. Carl Woodring, studies in Romanticism 21 (1982): pp. 445-474.

45. One aspect of this self-delusion was his condemnation of Maturin's Bertiam as a Jacobinical drama, a condemnation which comprises Chapter 23 of the Biographich Literaria. As Hazlitt was the first to point out, Coleridge's unfair review of Maturin was not only sour grapes (Maturin's play was produced while Coleridge's Zapolya, the play which followed Remorse, was rejected), but an obvious attempt to cover up his own Jacobin past by accusing Maturin of subversion. For a more complete discussion of this, see Alethea Hayter, "Coleridge, Maturin's Bertram, and Drury Lane" in Donald Sultana (ed.), New Approaches to Coleridge: Biographical and Critical Essays (Totawa: Barnes and Noble, 1981), pp. 17-37. For Coleridge's own account of his antijacobinism, and its debt to Burke, see chapter 10 of

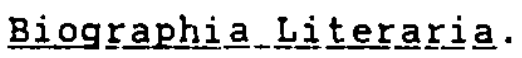

4ú. Remorse, in The Complete Poetical works, V, 286-294. The antijacobin nature of this change is noted by Moore, p. 463. 
47. For Moore, this nostalgia for Gothic spectacle is Coleridge's attempt to appropriate Gothicism for an attack against Napoleon. He argues that Coleridge's problem was not with spectacle, but with the Jacobin use of spectacle (p. 464). But Coleridge's problem is complicated by the anxiety over what constitutes "Jacobin" as opposed to antijacobin use, since the plays seem not quite clear on the distinction.

48. In Reiman, II, iv, 116 .

49. Letter to Thomas Love Peacock, July 1819, in Ingpen, Vol. X, p. 61 .

50.Reiman, P. 485 .

51.For stuart Curran, shelley inherits from Calderon the suspicion that everywhere you look is illusion--your own or someone else's--and that the drama can be a distorting perversion rather than a clarifying prism. See Curran, "Shelleyan Drama," in Richard Allen Cave (ed.). The Romantic Theatre: An International Symposium (Totawa: Barnes and Noble, 1986), p. 69 . 52.As Robert F. Whitman writes, "In Count Cenci. . Shelley was a symbol of that tyranny, whether domestic, social, political, or religious, which he felt it was his lifelong duty to attack." See Whitman, "Beatrice's 'Pernicious Mistake' in The Cenci," PMLA $74(1959)$, p. 250 .

53. "Preface," p. 240. 
54. This familiar position anticipates the quotation from Maturil which I have included in chapter one.

55. See for example stuart Curran, Shelley's "Cenci": Scorpions R Inged With Fire (Princeton: Princeton University Press, 1970); Earl Wasserman, Shelley: A Critical Reading (Baltimore: Johns Hopkins University Press, 1971); Ronald Tetreault, The Poetry of Life: Shel ley and. Literary Form (Toronto: Uriversity of Toronto Press, 1987). Curran and Wasserman also set up the classic debate, picking up from shelley's own statements on the "Preface," as to whether Beatrice is morally guilty in the murdel of her father.

56. This well-worn phrase, originating with Berkeley, re-emerges in Shelley's "A Defence of Poetry" as "All things exist as they are perceived. . ." (p. 505).

57.For Michael worton, this preterition marks "the essential paradox of the play: there is a consistent and deliberate refusial by the playwright to name the atalysing action within the tragedy. . . " Thus, when a character cannot find a languag: for thought, s/he will invariably "be forced to find expression in a non-verbal way--in action." See worton, "Speech and silence. in The Cenci." in Miriam Allott (ed.), Essays on Shelley (Totowa: Barnes and Noble, 1982), pp. 107-108.

58. The Figure of Theatre (New York: Columbia University Press, $1986)$, p. 18 . 
59. The connections between theatricality and self-annihilation are discussed by David Marshall in The Surprising Effects of sympathy.

60. Paine here is defending the National Assembly in France by arguing that it did not persecute its conspirators; rather, it was preoccupied with the contemplation of a constitution based on the authority and rights of the People. Paine's optimism seems rather misplaced in the light of event in 1793, a year after the publication of his tract. 
Chapter Four:

The Epistemology of the Tortured Body

I

A young boy has been murdered. His lacerated body has been discovered near his home, the Castle Frankheim. The suspect: a ne'er-do-well from the rival house of orrenburg. But the suspect, once apprehended, is reluctant to confess; the proper means must be taken to extort a confession. When Osbright, the victim's brother, learns that the "proper means" are the rack, and that until Frankheim "had recourse to torture, not a single word would [the suspect] utter, but assertions of his own and his: master's innocence," he is outraged. For Brother Peter, who had watched the scene and who now relates the details to Osbright, this was a moment of great sympathetic inspiration-he heartily pities the suspect. But for osbright, this is an enraging judicial stupidity. Osbright had been relieved by the belief that Gustavus, Count of Orrenburg was responsible for the young brother's death, but now

[t]hat belief grew weaker with every question, which he put to brother Peter; he found, that while in possession of his strength and faculties the supposed culprit had most strenuously denied all knowledge of the crime; that the excess of torture had forced from him the declaration, that Gustavus of orrenburg had ary concern in it; that the name cf Gustavus had been 
suggested by the prejudices of the suspicious and exasperated father; and that the whole confession was compressed in the mere pronouncing that name, when the speaker was seduced into uttering it by the certainty of immediate release from tortures most excruciating $\cdot . \cdot .1$

Osbright's doubt is prudent. The tortured victim had lied. Young Joscelyn was accidentally killed by a wolf. The extorted confession was simply what the torturers wanted to hear and so the confession proves nothing. And the moral of the story: "of all the defects of the human heart, there is none more encroaching, more insidious, more dangerous than mistrust: viewed through her distorted optics, there is no action so innocent, no every-day occurrence so insignificant, that does not assume the appearance of offence" ( $p .57$ ).

When Osbright rejects the evidence gathered under pain of the question, he indicates the ludicrousness of torture as a means of enquiry. And he is not alone in his outrage. In the last chapter. I discussed how violence was run off the stage of the Romantic theatre and was made the property of the imagination. At another venue, the same is true for the stage of the scaffold, and for public execution. As Edward Peters explains, by the late eighteenth century the use of torture was being abandoned by the courts of Europe as a remnant of the ancien regime. The use of torture--or the refusal to use it-became a symptom by which a nation could diagnose the state of 
its moral health.2 Michel Foucault has an even more interesting way of putting it: "At the end of the eighteenth century, torture was to be denounced as the survival of the barbarities of another age: the mark of savagery that was denounced as 'Gothic'."3 But such Gothic denunciation, I hope to show, connects to a larger problem in the Gothic novel: it actually registers an epistemological crisis that novels at the end of the eighteenth century had to explore.

Matthew Lewis's 1808 Romantic Tales articulates an outrage against torture, ard for two reasons. The first is the problem of uncertainty: as osbright knows, judicial torture proves nothing; it simply uses torture to affirm "the prejudices of the suspicious and exasperated father." While attempting to gather information, torture actually points to epistemological breakdown. Torture had always been in some way associated with the search for truth, ever since it was defined by ulpian, a third-century jurist, as "the torment and suffering of the body in order to elicit the truth"."4 And even though Cicero had known that torture was a self-contesting mode of enquiry, that did not stop Eurcpean courts from reaping the benefits of coerced confession. Throughout medieval jurisprudence, the tortured body was considered to offer direct access to guilt, and consequently to truth: tormentum (to torture) is even etymologically linked to torquens mentum--the "twisting of the mind" to wring out the truth. Elizabeth Hanson has analyzed how, in the Renaissance, Cartesian dualism wreaked havoc on the social institution of 
legal enquiry by reifying the schism between interior motivation --the "real" site of guilt--and the body that displayed this guilt.5 Renaissanze torture displayed not only a crisis in enquiry, in that the body couid no longer be counted on to speak the truth, but it also displayed a crisis in epistemology, in that it constructed the internal subjective space that it then could not violate ( $p .38$ ). The body could no longer be invested with the certainty it had been granted by, say, England's star Chamber or the Holy Inquisition (two notorious agents of torture), and had to be distanced from the legal procedure it was once so necessary to. And since recourse to torture was always a last resort in reaching a judicial conclusion, torture could only be used after all other time-consuming methods had been tried, and after the courts had been tied up for too long in costly litigations. Thus, some two hundred years later, Lewis's Osbright could take as commonplace the inefficacy of torture as a mode of enquiry.

But the tale objects to something other than the practical inefficacies of torture. When the castle of orrenburg attempts to avenge the slander perpetrated on Gustavus, it kills Frankheim's herald and nails his head to the gate. Gustavus is as outraged at this act as osbright had been, but for a different reason: "has my castle been polluted by so horrible an outrage?" he demands ( $p .74$ ). Whereas Osbright objects on judicial grounds to the persecution of the body, Gustavus responds to the debasement and suffering of the victim. And while, strictly 
speaking, the castle orrenburg has not committed torture, it has undertaken a villeul intrusion into the private human body. It is this invasinn that enlightenment judicial reformers lobbied so strongly against. Since the publication of Cesare Beccaria's extremely influential An Essay on Crimes and Punishments in 1764 , the question of torture became less a judicial and more a moral one. The rational concern for the judicial use--or uselessness-of torture that so clearly plagued the Renaissance lawmakers in Hanson's discussion was gradually replaced by what Pieter Spierenburg calls a "critical threshold of sensibility,"6 a sense that the spectators of torture actually identified with and shared the pain of the accused undergoing the question. This emphatic sensibility down-played the phenomenon of torture as a judicial, epistemological question and elevated it as a moral one, thereby privileging sensitivity over rationality, identification over disengagement, and in a larger sense, the inside over the outside. These binarisms arise in Beccaria's on Crimes and Punishments, ${ }^{7}$ but, as $I$ hope to show, are unstable and problematic to the reformist task. If Beccaria's essay is indeed the most influential text in judicial reform, then its curious mixture of rationality and sensitivity is a place to begin an understanding of the tortured body in the Gothic novel. Beccaria sets up the problem that writers of fiction--such as Lewis, Percy Shelley, and William Godwin--will have to face. 
I I

As the frequent citations in Blackstone's Commentaries demonstrate, Cesare Beccaria became the primary spokesperson for the enlightened eradication of torture from the courts. In an address to the reader in the second edition of An Essay on Crimes and Punishments, Beccaria asserts that his study of torture is "designed to ward of the unenlightened and excitable masses" from imitating the laws, those "dregs of utterly barvarous centuries," by which countries have sanctioned the use of torture (p. 4).9 There can be no room in jurisprudence for irrational and unbridled passions. Beccaria sought to replace these highly superstitious models with an enlightened judicial procedure that would be thoroughly rational: all penalties should be evaluated on purely utilitarian grounds. Punishments must be useful, necessary, just, and effective (p. 10). Only through this rationality would legal reform ensure "the greatest happiness shared by the greatest number" (p. 8), a slogan the British associate with Jeremy Bentham but which Bentham probably first read in Beccaria. The linchpin of Beccaria's logic, one that goes as far back as cicero, is the conflict of interest to which torture submits the body:

it tends to confound all relations to require that a man be at the same time accuser and accused, that pain be made the crucible of truth, as if its criterion lay in the sinews of the wretch. (p. 31) 
rineteen years later, Sir William Blackstone would footnote Beccaria and repeat the same charge, that it is ridiculous to rate "a man's virtue by the hardiness of his constitution, and his guilt by the sensibility of his nerves!"10 Ultimately, the problem with torture is that it confounds the Cartesian dualism upon which reason--and epistemological certainty--is founded. Reason for Descartes exists in conjunction with the senses but in mastery over them. Any rationalist judiciary process must be based on evidences that are demonstrably true through pure reason. Torture reverses the relationship of reason to sensation, says Beccaria, by privileging sensations over the master-mind:

Every act of our will is invariably proportioned to the force of the sensory impression which is its source; and the sensory capacity of every man is limited. Thus the impression of pain may become so great that, filling the entire sensory capacity of the tortured person, it leaves him free only to choose what for the moment is the shortest escape from pain. (g. 32)

Hence, the suspect's confession in Matthew Lewis's tale.

The privilege that Beccaria affords to logical truths extends to his radical assertion that the law should not concern itself with the accused's motives: rather, it must only judge the suitability of his actions to the larger community (p. 15). But Beccaria's attempt to remain outside the accused's subjective space is then somewhat undermined by a segue from the rationa? 
into the sentimental. In a passage worthy of Godwin's caleb Williams, Beccaria identifies what should be the motivation of law reformers:

- . the groans of the weak, sacrificed to cruel ignorance and to opulent indolence; the barbarous torments, multiplied with lavish and useless severity, for crimes either not proved or wholly imaginary; the filth and horrors of the prison, intensified by that cruellest tormentor of the miserable, uncertainty--all these ought to have roused that breed of magistrates who direct the opinions of men. (p. 9)

This appeal is problematic in that it allows the body to demonstrate an internal space of emotion and sentimert that Beccaria argued must be kept tightly closed. In other words, Beccaria advocates that pity rush in where reason has feared to tread, that the eradication of torture should be founded in sympathetic identification rather than detached logic. For Alessandro Manzoni, the Italian novelist whose novel The Betrothed is a fictional illustration of his grandfather Beccaria's reform tract, the passage marks the elder's characteristic "overflow of spontaneous inspiration" that masquerades as "a work of premeditated study." 1 For Henry Paolucci, a recent translator of the Essay, outbreaks like this one are a convoluted attempt to cover for Beccaria's marked ignorance of judicial history (including his apparent misinformation regarding the actual state of affairs in the 
courts, that is, that even prior to his publication, torture was dead or dying in most European courts.12) But this is not simple idiosyncrasy. Charles Taylor agues that, as confidence in the Deistic order of the universe waned in the eighteenth century, radical enlightenment thinkers had to maintain the belief in the primacy of human benevolence in order to provide for themselves some moral foundation for their enterprise.13 Feeling, which they tried to make coterminous with scientific logic, was the. origin of all reformist and enlightened thought. But it still presented problems. One of Beccaria's opening premises had beal that "No lasting advantage is to be hoped for from political morality if it. is not founded on the ineradicable feelings of mankind" (F. 10), but it is precisely these feelings that att elsewhere described as "the tenderest feelings and most violen: passions" that play "on men's hearts like musicians on instruments" (p. 4l). In essence, Beccaria has worked himself into a corner: reason is dependent upon ineradicable feelings, but such feelings can manipulate and pervert reason. He has posited a thoroughly rational, syllogistic treatment of the body, but then he has advocated a sensible and emotional awareness of that body. In so doing he undermines the distance/identification paradigm upon which his judicial theory rests, and demonstrates, what Jurgen Habermas would call a legitimation crisisi 4: jurisprudence in Beccaria's text is both defined and threatened by the agencies of sentimentalism. 
By the "agencies of sentimentalism" producing a judicial "legitimation crisis," I am referring to that general tendercy of the late eighteenth century to collapse the distance that Descartes had placed between bodies and souls. This distance occurs in two piaces. First, as John Mullan notes, eighteenthcentury sensibility obscured the distinction between one's moral, sensibia relation to external stimuli and one's internal. physiological reaction.1 3 with sentimentalism, the body once again became a demonstrable space that could emphasize the internal, affective life of the soul in a way similar to the medieval correspondence between vice and physical deformity. The legal implication of this return--at least for Gothic fiction-is a nostalgia for the body as an unmediated testimony of vice or virtue. Often, we see in the physiognomies of Gothic characters an easily readable guilt or innocence: good guys are beautiful and bad guys are ugly. This easy correspondence was belied in, say, Lear's Edmund or the Restoration's handsome rake-villain, whose bodies mapped that separation that Cartesian dualism had created. Such bodies successfully hid their internal spiritual state. (And this ability--to hide, or to lie--brings us back to judicial reform: it is what renders torture useless as enquiry.) However, with the attempt to redress the social and epistemological implications of dualism came the renewed attention to the body as a possible site of the spirit. Second: $y$, this attempt to redress dualism undermined--partially-the Cartesian division between subjects, a division predicated or 
the isolation of the soul. Sentimentalism invited the subject to feel what the other person was feeling, and to construct a dialogic community between subjects. Given this, the crisis in law that runs through Beccaria's text and gets picked up in the Gothic is this: the body in pain is both highly charged in its emotional moral appeal, yet untrustworthy all the same. In a curious paradox, the sacred abstraction of the body in the late eighteenth century becomes the greatest enemy to a judiciary trying to secure its protection. Rationalist jurisprudence and emotive sentimentalism, both of which underwrite Lewis's tale, seem to be mutually exclusive epistemologios when one is viewing the body.

Beccaria's response to the threat that a sensitive body poses for a rationalist judiciary is to fashion punishment that works as a gentle deterrent rather than as a barbarous demonstration of punitive power. The more torture is used, he reasons, the less effect it will have, because people will grow used to the idea of it (p. 43). Rather,

It is not the intensity of punishment that has the greatest effect on the human spirit, but its duration, for our sensibility is more easily and more perfectly affected by slight but repeated impressions than by a powerful and momentary action. (pp. 46-47)

Punishment should be threatening, omnipresent but rarely enacted, imagined rather than exercised, existing mostly in the future tense. Whereas earlier in the tract, Beccaria had called 
uncertainty "that cruellest tormentor of the miserable," here uncertainty becomes a most useful criminal deterrent. For

spierenburg, such a move demonstrates the increased sensibility that wanted to remove grotesquerie and torture from public view because the spectators could actually feel the tortured virtim's pain (pp. 184-185). (And in this sense the eradication of torture markedly parallels the eradication of stage violence that I discussed in the previous chapter.) subjected to Foucault's hermeneutic of suspicion, the move to gentler modes of correction simply recast the semiotics of state power as they were exercised upon the body, and empowered various state apparatuses--the prison, medicine, psychology, religion--to define their specialized states of "normalcy" to which they could then submit the body. Gentler correction, for Foucault, merely helped to fix the causal relationship of crime and punishment within the mind of the public, so that torture need no longer be used. In either case, what Beccaria is articulating here is a way of maintaining social control without resorting to the immediacy of the body and all its vicissitudes. In other words, Beccaria uses a strategy to get rid of or to compartmentalize the sensitive body in order to diminish the possible contradictions or underminings it presents to the rationalist elements of its program. This strategy, I want to suggest, also informs writers of Gothic fjction. Just as in Beccaria, the scene of torture in Romantic fiction evokes a legitimation crisis in viewing the body, a 
crisis that requires a way of down-playing the body's sentimental effects.

One such example of Romantic fiction comes from Percy Bysishe Shelley, whose literary career virtually begins with torture. His early novel zastriozzi, written in 1805 when shelley was eighteen, relates the convoluted revenge plot of its titular villain who attempts to murder the hapless verezi, the son of his mother's seducer. Zastrozi, like many a Gothic villajn, is exposed for his crimes at the end of the novel and dragged away by the Inquisition to endure the rack. But what is curious here: is that the enquiry-by-torture comes after he has made a full confession. By now the Inquisition knows that zastrozzi is; guilty and that he acted with an accomplice (Matilda), and so it has nothing to enquire or discover. Thus, its infliction of pain becomes a metaphorical guid.pro.guo, administering punishment for crime in a strictly causal relationship, rather than using torture as a means to obtain information. By a judicial sleight. of-hand, the novel transforms torture from enquiry into punishment and, in so doing, indulges its Gothic sensation without indulging the judicial contradiction.

At an obvious level, Shelley is drawing on a popular novelistic convention that was flooding the popular presses in the early nineteenth century (and that would appeal to a tefnager looking for instant fame). But the use of torture here is not only sensationalism. The implications of inflictirg pain or 
Zastrozi's body, and proclaiming the truth of his guilt, reverse the general treatment of his body throughout the novel. Whereas the first chapter foregrounds the immediacy of Verezi's body--he is forcefully abducted, shackled in a dungeon, and forced to suffer reptiles slithering over him--our first sight of zastrozi is no sight at all: he is masked, elusive, and moving about in the dark.16 When we finally do see his face and figure, we learn little more than does the bewildered verezzi, who has no idea why he has been kidnapped. Zastrozzi's body is unreadable; it conceals an inner truth. As he tells Matilda, My maxim. . . through life has been, wherever I am, whatever passions shake my inmost soul, at least to appear collected. I generally am; for, by suffering no common events, no fortuitous causality to disturb me, my soul becomes steeled to more wonderful trials. I have a spirit, ardent, impetuous as thine; but acquaintance with the world has induced me to veil it though it still continues to burn within my josom. (p. 47 ; emphasis original)

Characterised by its dualism, Zastrozzi's body is a shield, an impediment to the truth, as opposed to the sentimental hero whose body broadcasts his/her internal state. Given this configuration in which the body hides the soul, torture is used to "get inside," and to get at the truth. It externalizes the internal, and makes of the body the site of proclaimed guilt. Shelley gets around the cartesian body-problem here by simply ignoring it, or 
by returning to a vision of the body as it existed before Descartes, in which the flesh could telecast the state of the soul. In this way, his early Gothic novel documents that conservative morality for which the Gothic, pace Sade, is famous.27 Torture here is both poetic and criminal justice: by reuniting the body with the soul, the state reads the guilt written on the body, and thereby circumvents the epistemological problem that torture had always evoked. Without the text's slightest allowance for uncertainty or the moral ambivalence that accompanies it, Zastrozzi's torture is unquestionably effectivt.

The case is much more complicated in shelley's later Gothic work, The Cenci, a work I discussed in more detail in the previous chapter. Like zastrozzi, The Cenci unquestioningly utilizes torture to "solve" the crime around which the final act circles: the murder of the tyrannical father, count cenci. "[w]ith lips yet white from the rack's kiss" (v,ii,9), the assassin Marzio confesses that he killed the Count who lay sleeping in the castle of Petrella. Furthermore, he admits, he: was urged to the crime by

[Cenci's] own son Giacomo, and the young prelate Orsino sent me to Petrella; there, The ladies Beatrice and Lucretia Tempted me with a thousand crowns, and I And my companion forthwith murdered him. Now let me die. (V,ii,14-19) 
On the one hand, this torture aciequately performs the state's legal business: it exposes both criminal and accomplices without the slightest recognition that such exposure may not be trustworthy. Even when Marzio repeats, "I have told alli/ For pity's sake lead me away to death" (V,ii,110-1ll), the Judge and detectives do not clue in to the fact that he might be trying to avoid further examination and torture. But in another way, Shelley demonstrates an awareness of the problem that Beccaria faced in the highly charged sentimental body. It is significant, I believe, that while shelley has Marzio tortured, he does so off-stage. I argued in the previous chapter that the body provided problems for shelley's idealistic project in The Cenci, in that its vulnerability and fragility could inspire sympathy for a tyrant like cenci. In the torture scene here, the same problem re-emerges. But the spectacle is not only the stage of Covent Garden here; it is the stage of the scaffold. To torture Marzio on stage is to invite a sympathetic response to him, and to make his body more potently charged than any other on stage. Since shelley's project in this play is to present the trials of Beatrice, and to have the audience focus on her., he must downplay any victimization that might detract from her. If the ultimate aim of the drama is to teach "the human heart, through its sympathies and antipathies, the knowledge of itself,"ls then such an idealistic internalized project cannot afford to be compromised by a cheap scene of bloody spectacle. Shelley is aware of the humane declamations against torture, but he is also 
aware that the potential for human sympathy that underlies these declamations car. interrupt his dramatic project. As I discussed earlier, torture can invite a sympathy for the devil (cenci, Marzio). And that sympathy, and the excessive outrage it can provoke, can detract the spectator from an awareness of his/hel own responses, the knowledge of his/her own heart. In the case of The Cenci., then, didactic idealism necessitates that the tortured body be kept from public view.

Shelley's good taste, it would seem, has a very practical motive: he consigns the tortured body to the wings in order to minimize the problem that plagued Beccaria, the problem of torture actually interrupting the judicial program. Shelley's depiction of torture as practical, useful, and unsentimental is; part of a legacy he shares with his father-in-law, william Godwin, who was working out the same problems ten years earljel. For Godwin, the mutual exclusivity of rationality and sentimentalism, and their relation to judicial enquiry, ate crucial to the development of his political philosophy. In thr. 1793 Enguiry Concerning Political Justice, which would exert. great influence on Shelley, Godwin tells us that the "subject of punishment is perhaps the most fundamental in the science of politics"l 9 because it proceeds directly from the social contract; that is, it defines the rights and limitations that protect one citizen from the violent forces of another. Judicial law is fundamental to a definition of individualism (a defirition 
that is the ultimate project of the Enguiry) because it demarcates the powers by which all social institutions may potentially compromise the individual. But it is this whole emphasis on individualism that opens up the epistemological problem for Godwin. On the one hand, he shares with Beccaria (whom he quotes copiously) the conviction that punishment must always be determined by a just and rational process of enquiry. For Godwin, there is no such thing as a freely committed crime: "The assassin cannot help the murder he comnits" (p. 633). Rather, he is the victim of Necessity, of the inevitable chain of circumstances that forced him to commit it. And so, reason dictates the eradication of those circumstances that will, in turn, eradicate the need to commit crime. But on the other hand, reason must allow that the heinousness of a crime is often necessarily determined by motives: first-degree murder must meet with sharper punishment than involuntary manslaughter, the crucial difference being the offender's motivation or intention. It is precisely the identification of this motive that troubles Godwin. He argues that

Man. . may, in a certain sense, be affirmed to consist of two parts, the external and the internal. The form which his actions assume is one thing; the principle from which they flow is another. With the former it is possible we should be acquainted; respecting the latter there is no species of evidence that can adequately inform us. (p. 649) 
Thus, the "inscrutability of intention" (p. 650) poses an epistemological problem, a "mystery" (p. 653) that we can never adequately penetrate. We may "reasonably enquire first into ltht accused's] intention, but when we have found this, our task is but begun" (p. 654). And that task, as Godwin outlines it, moves away from internal motivation and into the dismantling of social circumstances that cause crime. Whereas shelley's conventional Gothicism will get around the "inscrutability of intention" by equating the internal with the external in torture, Godwin remains aware of the problems it poses. The internal/external dualism is both essential and antagonistic to criminal justice as: Godwin outlines it in the Enguiry.

The role of the inside/outside structure in both establishing and threatening the very foundations of criminal justice is a particularly acute problem for Godwin as a political philosopher and novelist. Since Leslie stephen's influential analysis in 1902, many Godwin critics have seen an antagorism between his rationalist project in the Enguiry and the more personalized emotional and psychological histories of his latel novels. Godwin himself characterizes the Enquiry as an attempt to reason as "an impartial spectator of human concerns" ( $y .76)$, whereas Caleb will $\underline{\text { iams }}$ purports to appeal directly to "a very powerful interest." 20 Hence it is a commonplace in Godwin criticism that his life moves from the subject-position of rationalist-anarchist political philosopher to that of emotional, sympathetic novelist, a move usually located between the first 
and second editions of the Enquiry. Mitzi Myers attributes this change to the death of Mary Wollstonecraft, Godwin's writing of her biography, and his reconsideration of the importance of domestic affections contained therein. Myers quotes Godwin from Thoughts on Man as she argues that he came late in life to see sympathy as "the epistemological ground of all philosophy, the only reality of which we are susceptible. . . our heart of hearts'. . ."2l Here, the internal life is given a privileged space that was carefully closed off in the earlier work, and it is a space that, I hope to demonstrate, magnifies the problems of a rational jurisprudence with a human face in much the same way that it did for Beccaria.

While Godwin may applaud the incorporation of domestic affections into the rationalist (perhaps masculinist) agenda of the Enquiry, this progression is not without its difficulties. In his preface to the 1799 novel Travels of st. Leon, Godwin discusses the changes in his thinking since the first publication of Political. Justice in 1793 :

Some readers of my graver productions will perhaps, in pursuing these little volumes, accuse me of inconsistency; the affections and charities of private Iife being every where in this publication a topic of warmest eulogium, while in the Enquiry concerning Political Justice they seemed to be treated with no gr...t degree of indulgence and favour. In answer to this ob, ction, all I think it necessary to say on the 
present occasion is, that for more than four years, I have been anxious for the opportunity and leisure to modify some of the earlier chapters of that work in conformity to the sentiments inculcated in this. Not that I see cause to make any change respecting the principle of justice, or any thing else fundamental to the system there delivered; but that I apprehend domestic and private affections inseparable from the nature of man, and from what may be styled the culture of the heart, and am fully persuaded that they ale not incompatible with a profound and active sense of justice in the mind of him that cherishes them.?

A number of points are significant here: there is no need to change tine principles of justice; public policy still requires rational utility. However, principles of justice must be tempered with affection in anyone who reverences them sufficiently. In other words, characters must display the proper motives. With this proviso Godwin does not so much achieve a great union of affections and justice, as Myers argues, but rather sets up the conditions for keeping them divided. By declaiming that affections bond with rational justice only "in the mind of him that cherishes them," he allows for the possibility of a certain social policy that remains distinct from the domestic, affectionate one: in other words, those who do not cherish affections may be treated under the rubric of utjlitarjan rationalism. 
This is the problem in the 1805 novel, Fleetwood: or The New Man of Feeling, in which the protagonist is plagued by this very conflict between passion and reason--both in his domestic affections and in matters of law and public policy. The novel squarely sets affections and emotions against a rationalist program to demonstrate that affections and rationality are always intertwined, mutually defining, and mutually problematic. This interrelationship throws into question the paradigms I have outlined above--rationality/sensitivity, distance/identification, outside/inside--as necessary to but estranged from a "proper" mode of enquiry. Furthermore, it is significant, I believe, that Godwin sets the whole question within a framework of judicial enquiry, punishment, and torture. Fleetwood uses the model of judicial enquiry and punishment to try to sort out his domestic problems, but with that model comes the problems of how one reads motivation in general and the body in particular. What we see in Fleetwood is the same legitimation crisis that tormented Cesare Beccaria, where the body is the site of both sympathy and deception. The novel carries this crisis into the domestic realm in an attempt to reconcile Godwin's internal, emotional impulses with his disengaged, utilitarian rationalism.

Throughout most of the novel Casimir Fleetwood is a misanthrope, and it is the project of the book to document the stages of that misanthropy. As the narrator, Fleetisod traces the development of his misanthropy from the young Wordsworthian 
solitaire, through the distanced and disillusioned oxford student, to the misanthropic adult. Like Falkland in Caleb Williams, Fleetwood hates humanity because of the circumstance: he has encountered: cruelties among his university mates, deceptive women, pretentious wealth, and corrupt government. The central plot centers on his marriage to the pure and innocent Mary who, thanks to the evil deceptions of Fleetwood's nephew Gifford, appears to have been unfaithful to Fleetwood. (She hasn't been, of course.) He leaves her and travels to Italy where he decides he will cut her of from his money and sue hel for adultery. While in Italy, he sends for some of Mary's clothes, out of which he constructs life-sized malnequins of hel and Kenrick, the supposed correspondent. These he proceeds to torture and "vivisect." on his return to England, he is attacked by highwaymen who attempt to murder him, but is quickly rescued by an unidentified saviour, who turns out to be Kenrick. Wher he discovers that Gifford staged the adultery and attempted the murder-for which Gifford is hanged at a public execution-Fleetwood returns to his life with Mary and the domestic affection for which Mitzi Myers had such great hope above. But Fleetwood's marriage is always shadcwed by the tensions of disbelief and paranoia: we get the sense that he will rever really be sure that Mary is totally trustworthy. In fact, Fleetwood's problem throughout the novel, as we shall see, is that he can never really be sure of anytring. It is because of this uncertainty, and its relation to enquiry, justice, ard 
domestic affections, that Godwin will take the sentimental

premises of his predecessor, Mackenzie's Man of Feeling, and explore the epistemological problems of sentimentalism as they inscribe themselves on the judicial body.

The problem of sentimentalism in legal enquiry becomes a primary focus when, near the beginning of the novel, Fleetwood recounts a practical joke from his days at oxford. The joke involves Withers, a would-be tragedian who fashions his taste and intellect as superior to those of his peers, Fleetwood's friends. These friends arrange a mock-reading of withers's play, at which the playwright becomes drunt and riotous. He is summarily called upor to stand trial before a "judge" who is nothing more than a life-sized doll made for the occasion (a doll that, obviously, prefigures the one that Fleetwood will construct later on). At the trial withers finally realizes the degree to which he is being ridiculed and, out of humiliation, he kills himself. For Fleetwood the whole sordid scene is reducible to a moral lesson, as he expresses his sympathy for Withers:

It is suffering only. that can inspire us with true sympathy, that can render us alive to those trifles which constitute so large a portion of earthly misery or happiness, that can give us a feeling of that anguish, which, sometimes in human beings, as most evidently in the brute creation, works inwardly, consuming the very principle of life, but has no 
tongue, not the smallest sound, to signify its excess, and demand our pity.23

These sentiments of course echo a tradition of Moral Sense Philosophers to which I alluded in chapter one, philosophers such as Adam Smith, for whom the imagination puts us in the place of the sufferer: "we conceive ourselves enduring all the same torments, we enter as it were into his body, and become in some measure the same person with him, and thence form some idea of his sensations. . . "24 This is the Man of Feeling as he comes to us in Mackenzie. While Smith does base his statement on the premise that "we can have no immediate experience of what other men feel," he does envision a sensibility-as-moral-community, one that blurs the division between self and other and replaces it with a single dialogic "inside." As in the sentimental Radcliffe heroine, the philosophy of observed suffering in Fleetwood proclaims "I know how you feel."

While Fleetwood may have found in sentimental doctrine an easy and satisfactory summation to this whole unpleasant incident, his behaviour throughout the scene is much more complicated. His privilege of sympathy's ability to create a community of subjects loses its force when juxtaposed with his equally forceful defense that he was certainly never involved in the taunting. . or if he was, he didn't enjoy it much. His is a bad faith that will become more important at the end of the novel: "For myself. . I had no relish for this amusement. Once or twice, inconsiderately and precipitately, I yielded to 
the importurity of my companions, and became entangled in such adventures; but I presently abjured everything of that sort . . "(p. 38). In his interpretation, the whole incident was really. Withers's fault: "he had given himself up passively from the beginning to the ideas which his deluders wished to excite in him. . " (p. 36). Thus, as Fleetwood puts on trial his own moral worth and the behaviour of withers, he ostensibly claims a sympathetic community with the victim while actually rationalizing himself into a position of guiltlessness. This entire scene, and the way it prefigures the climactic trial and enquiry of Gifford at the end of the novel, establishes a dual discourse in Fleetwood: it posits both a sympathetic man of feeling, like Mackenzie's Harley, and a disengaged individualist, like the logician of the Enquiry. It maintains a division between self and other, between inside and outside, that undermines its more benevolent claim.

What unites these two discourses is the suspicious role that perception plays in Fleetwood's affairs. This perception is a Romantic, creative consciousness through which Fleetwood perceives the world and which leaves him bitterly disillusioned. As he leaves oxford and travels to France, he falls in love with a "faithless" woman who deceives him or, more accurately, demonstrates to him that he has deceived himself. He concludes from this that when an imaginative spectator watches objects in the empirical world, he sees not "the things themselves... . [but] the growth and painting of his own mind" (p. 56). Nothing 
exists but as it is perceived, and would that he and withers before him had realized this in time. Furthermore, this construction of the world directly relates to the sentient body, to the mechanics of judicial enquiry, and to the formulation of an epistemology. Above, Fleetwood used the notion of suffering as a medium for constructing community: I know how you feel. But when he pursues the medium further, to the point of using torture and physical pain as a metaphor for creating this community, we find a confusion in who is feeling what, or whom:

I do not wish to stand alone, but to consider myself only as part of a whole. If that which produces sensation in me, produces sensation no where else, I am substantially alone. If the lash inflicted on me, will, being inflicted on another., be attended with similar effect, I then know that there is a being of the same species or genus as myself. (p. 179;

emphasis added)

The knowledge of someone else's pain here seems tautological: we: are a community not because I feel your pain, but because I think. you feel mine. Your feeling, the experience of your sentient body, becomes nothing more than the growth and painting of my own mind. The sentimental body, wishfully a decentralized and dialogic site of subject relations, becomes inscribed as object, as other, the repository of the perceiving subject's vested interests. As the Marquis de Sade well knew, sentimentalism 
provides a communal body that destroys its own potential for community. 25

The attempt to know the other's body--an attempt that communal sentimentalism invites but which is then destroyed by it--is at the heart of Fleetwood's psychological problems in the novel. For his psychological problem is also an epistemological one: he never knows for sure how he is to read someone else's body, and how he is to interpret the inside by reading the outside. In the terms set up by the Enquiry, Godwin's protagonist can never read motive. For example, he focusses on the physiognomy of Gifford and compares it to that of Mary and Kenrick as an exercise in body reading:

Under the olive-tinctured skin of Gifford, beneath his scowling brow, and among the lines which time and climate have indented there, hypocrisy might hide herself; but in the other two, there is no opacity or discoloration to intercept the passage of a thought, there is not a furrow in their cheeks for treachery to lurk in. Mary, Heaven has moulded its own image in thy features: if thou art false, oh, then Heaven mocks itself. (p. 292)

Like a modern advertisement for acne creams, this passage argues that a clear complexion is enough for an astute reader to read through its transparent signification to the goodness therein. But Flertwood does not consistently trust his ability to read the body. Moments after this encomium, when Gifford fashions another 
lie, Fleetwood is just as willing to believe it as he had been to believe in Mary's guilelessness. And the most convincing proof that Gifford can offer is not the objective, factual "evidence" of adultery (read: manufactured illusions), but rather the signification of his body: "His visage was colourless; his eyes averted with a mournful air; his hands hung down, as languid and incapable of motion.. . . I need not ask you'" for particulars, says Fleetwood. "I read it all in your countenance" (p. 297). Fleetwood's overarching problem here and generally, I would suggest, is his tendency to want to read the body as a site of unmediated truth as a way of settling these disturbing questions. Undetermined motivations and impenetrable, mysterious hearts are profoundly unsettling, as the Enguigry well knows. But, as Fleetwood also knows from his reading of Gifford's "olive-tinctured skin," and from his own paranoia, answers cannot be found on the body; this supposedly readable site can conceal hypocrisy, and thus the body cannot be trusted. In response to a critical breakdown in epistemological paradigm, Fleetwood must insist on a naive belief--which to a degree he knows is naiventhat the sentimental body offers a sound hermeneutics, that it can ground an epistemology of motives even though that epistemology is contradicted by rational evidence.

This hermeneutic is similar to that in Beccaria, who threw into crisis the agencies of sentimentalism and rationalism as contradictory grounds for jurisprudence. In Godwin, the crisis lies at the intersection of the rationally empirical--what ore 
sees--and the affectively experienced--what one feels, in that you can't believe everything you see or feel. It is a crisis founded on the tenuous distinction between inside and outside, in which the inside colors and creates the outside. Fleetwood's response to this crisis is to envision an outside--which he will adopt as the public, judicial body--that can still be legitimately separated from the private, domestic body. Remaining true to the unchanged principles of justice, he must leave the judicial body outside the coituscating agencies of sentimentalism. This vision, I want to argue, constitutes the latter section of the novel, and is established by two scenes of torture, scenes that carve out very different and mutually exclusive possibilities for the sentimental body.

By the middle of the novel, Fleetwood has received sufficient information (all lies) from his nephew Gifford to prove that Mary is guilty of adultery. And Hell hath no fury like a husband cuckolded. His reaction is to want physical violence, to extract a confession from her with "red-hot pincers" (p. 325). As Elaine Scarry explains in The Body in Pain, we tend, in the most profound moments of doubt, to turn to "the sheer material of the human body" for some sort of confirmation (p. 14). Fleetwood seeks punishment, rather than enguiry, in the same way that many Gothic novels often transform the ambiguous enquiry of torture into a confirmed and sure punishment. But since he can't extract such a confession, he constructs wax dolls 
resembling Mary and Kenrick and, making his preparations with a "tormenting pleasure," proceeds thus:

I gazed at the figure of Mary; I thought it was, and it was not, Mary. With mad and idle action, I put some provisions on her plate; I bowed to her in mockery, and invited her to eat. Then again I grew serious and vehement; I addressed her with inward and compulsive accents, in the language of reproach; I declaimed, with uncommon flow of words, upon her abandoned and infernal deceit; all the tropes that imagination ever supplied to the tongue of man, seemed to be at my command... But, while I was still speaking, I saw her move--if I live, I saw it. She turned this way and that; she grinned and chattered at me. I looked from her to the other figure; that grinned and chattered too. Instantly a full and proper madness seized me . . . I rent the child-bed linen, and tore it with my teeth. I dragged the clothes which Mary had worn, from off the figure that represented her, and rent them into long strips and shreds. I struck the figures vehemently with the chairs and other furniture in the room, till they were broken in pieces. (pp. 334-335)

The spectacle of suffering here is markedly different from Fleetwood's experience with Withers or indeed, with the judicial infliction of torture in general. Clearly, Fleetwood's private search for some understanding of his domestic situation is not 
the same thing as the state's terrorist mechanism of torture. But what Fleetwood's action here has in common with the scene of torture is its imaginative projection of what Fleetwood wants Mary to be: the torturer creates the truth he wants to hear. Fleetwood imagines the wax figure to be Mary and for the purposes of his own desires, wishing makes it so. She moves; she chatters; she is alive. And because she is alive, she can be tortured and made to feel pain. But interestingly, it is only the imaginatively constructed Mary that is alive and potentially capable of sentience. The moment he makes contact with her and inflicts pain on her, she becomes "the figure that had represented her," a distanced object, a puppet on a stage. When Fleetwood encounters a body as a sentient, alive other, that body becomes an object and not Mary herself. The scene is a paradigm of imaginative projection where the other in the object world becomes completely defined by the paintings of the subject's mind. "Mary" is both a living, sentient being and an insentient figure, both animate subject and inanimate object.26 and the dividing line, that which separates the animate from the inanimate, is the sentient body, a body that simultaneously invokes sympathetic knowledge and precludes it.

Moreover, the scene emphasizes the limitations of what can be known about the other's body. The act of inflicting torture, says scarry, demonstrates the knowledge of what is painful. It articulates the usually unarticulated experience of pain, in which the "I" expresses presence by orchestrating pain in 
another's body. Godwin says as much in the Enquiry, when he defines torture as a demonstration of "my power to inflict - . being placed in my joints and sinews" (p. 641). Obviously then, the effigy scene is intended not only to rid Fleetwood of bottled-up hostilities, but to give him a sense of power, of the individual autonomy that B.J. Tysdahl argues is so important to Godwin's characters, 27 and which the sentimental body jeopardizes. This power is granted in two ways. First, as we have just seen, it constructs a concept of "Mary" that is immediately rendered object, a body incapable of sentience. This insentient object-body, furthermore, is also incapable of both the autonomy and the communality that the earlier sentimental body had implied. Second, torture individuates and empowers Fleetwood by giving him a language, a way of expressing the impotence he has secretly been fearing. Unleashed violence results in unleashed eloquence, the "uncommon flow of words... [and] tropes that imagination ever supplied to the tongue of man." The sympathy he had felt for withers had "no tongue, not the smallest sound to signify its excess," because clearly, the pain was not his. Here, however, he finds a voice. But the voice he finds does not signify his pity or create community: it is the voice of individualized pain and individualized power.

The isolating qualities of pain go even further than a mere proclamation of power. When Fleetwood has finished abusing the wax figures, he staggers into a chair with the following: 
I am firmly persuaded that, in the last hour or two, I suffered tortures, not inferior to those which North American savages inflict on their victims; and like those victims, when the apparatus of torture is suspended, I sunk into immediate insensibility.

(p. 335)

As Fleetwood assumes for himself the role of victim, we are given pause by a sudden reversal in the torturer-victim relationship. The confusion we feel is the same confusion felt by the reader of Cal eb. Will iams where, at the end of the novel, we are unsure who is the victim and who is the tyrant. This confusion results from overturning the sentimental paradigm in which the spectator enters into the victim's pain. Like his earlier sentimental self, Fleetwood projects himself into the body in pain. But the oxford ztudent's claim to sympathy--to the engagement of fellowfeeling that connects subject and object--is reversed by the adult's fantasy of subjection. He claims a monopoly of victimization that centers pain solely in himself and obliterates the object with which he had claimed to identify. In effect, the effigy scene enacts a series of bodily displacements: the effigy first replaces Mary's body, but it is then replaced by Fleetwood:s. He becomes the victim in the torture he has executed. He transforms the sentimental potential of the tortured body from "I know how you feel" tc "This hurts me more than it hurts you." And since hurting is, according to Elaine scarry, a totally individual and centripetal experience, 
Fleetwood's pain centers him fully within himself. By assuming the status of victim, Fleetwood indicates that the real victim's interiority--feelings, affections, motives-- can never be known. They can only be projected creations, the deluded paintings that he shared with Withers earlier on.28

It is at this point that Fleetwood loses his resemblance to the state torturer, and becomes more like the sympathetic spectator or reformist thinker. But in the transition, he demonstrates the limitations of that "critical threshold of sensibility" that spierenburg presents. When the pain of imagined torture returns to the one imagining it, he collapses into immediate insensibility. In effect, the imagination that creates pain then destroys itself. Once again, Elaine Scarry is helpful here. In chapter two I outlined scarry's argument that there is a basic incompatibility between imagination and pain. In acts of imagining, we are taken outside of our bodies; we create an external referent that is not ourselves, but rather an imagined materiality outside ourselves that cannot feel pain. (This was also the basic structure of theatricality underlying David Marshall's discussion of sympathy in the eighteenth century.) However, given that sentimentalism fosters the illusion that pain can be shared, and given that pain is, to a great degree, defined by one's consciousness or recognition of it, pain can to some extent be said to exist in the sentimental spectator. And in Fleetwood, that pain acts to destroy the imagination. As scarry writes, "world, self and voice are lost, 
or nearly lost, through the intense pain of torture."29 Thus, the scene of imaginative projection in Gothic fiction is structured as a dialectic: the perceiver projects the self into the object in pain, shares in that pain, and then suffers under that pain's very presence in the spectator's body. Put another way, imagined pain evokes the possibilities of the sentimental body but then destroys that possibility by objectifying and distancing that body.30 It assures us that, by being able to imagine another's body in pain, we cannot actually share in that pain. And so, sympathetic community is effectively undone. The imaginative construction of another's pain empowers the self and assures the continuous presence of the self being empowered. To some degree, the sympathetic spectator shares an affinity with the torturer himself, in that they both manifest what Maturin called that "glorious impenetrability," an actual feeling of triumph over those who suffer, rather than a sympathetic sharing with them.

Fleetwood's individuation, his empowerment through another's pain, provides the rubric by which we can interpret the final scenes of the novel, and Godwin's problematic treatment of the legitimation crisis he shares with Beccaria. Gifford's identity as Fleetwood's would-be assassin is discovered by pain of torture. Fleetwood gets this information from his benevolent nurse Martha: "They have given the valet the boots, they call it - a contrivance the French have to squeeze the truth out of a man--and he confessed that Gifford was at the bottom of all" ( $p$. 
343).31 While Martha unquestioningly trusts this confession, Fleetwood will have no part of its findings. Rather, he demands: Now Martha, learn from me, and blush for what you have said! Can you, a Briton, believe, that torture makes a man speak the truth? that, when he writhes in agony, and feels himself debased below a brute, his words are to be regarded as oracles? Would not a man say anything, to put an end to what he suffers? (p. 343) Fleetwood's response has that same ambivalence we saw in Lewis's story: torture is epistemologically unsound and morally reprehensible, debasing the creature below a brute. But while Fleetwood objects to the mode of extraction, he quickly accepts the truth of Gifford's guilt: he willingly suspends his disbelief in coerced confession if it helps with his own project of enquiry. Similarly, his reaction to Gifford's hanging is a blend of utilitarian logic and emotionally-charged revenge:

I have always regarded with horror those sanguinary laws which, under the name of justice, strike at the life of a man. For his sake I was willing to admit of one exception . . . What discipline, or penitentiary confinement, coulc. rationally be expected to inspire him with one touch of human nature? Die then, poor wretch, and let the earth, which labours with thy depravity, be relieved! (p. 371)

We hear in this speech the earlier Godwin, the man who wrote in the Enquiry that he would "inflict suffering, in every case where 
it can be clearly shown that such infliction will produce an over abundance of good" (p. 635). While suffering may inspire pity and demand sympathy, it can never truly reveal what is inside. Therefore, pity must not get in the way of the larger public good. The criminal and judicial body must always and only be a site for the discourses of reason, even if those discourses conceal a personal, selfish, impassioned agenda. If sentimentality were allowed to intrude, if we allow for "one touch of human nature," then the judicial process is undermined. The sentimerital body must be kept out. of judicial proceedings, in favour of a reconstructed, albeit fallacious, critical distance.

The revelation of Gifford's villainies is, among other things, a critique of disengaged, empiricist enquiry. The courts had found Mary and Kenrick guilty of adultery "upon the most demonstrable evidence" (p. 346), but that evidence turns out to be the product of manipulation, corruption, and bribed testimony. Gifford, it seems, was a "master-villain, whose task it has been to paint everytring in false colours, and to obstruct all the glimpses of truth and virtue. . " (p. 348). This conclusion, I believe, smacks of bad faith. True, Gifford did arrange all appearances, but to conclude that he acted alone is to assume that Fleetwood had a pristine, unbiased vision before meeting him. This is patently untrue. The image of painting in false colours is precisely the one Fleetwood had used earlier to criticize his own deceptive perceptions, although he conveniently forgets that here. Furthermore, a simple empirical explanation 
of all the facts that Gifford had obstructed does not exonerate Fleetwood from guilt or Mary from suspicion. Rather, they are always tainted by internal fears, secrets, feelings that should unite them:

It seemed as if, now that what the vulgar mind would call the obstacles to our re-union were removed, we were more certainly divided than ever... . Now we were separated by sentiments, that must for ever twine themselves with the vitals of every honourable individual, and that can only be exterminated by the blow which lays the head that has conceived them in the dust. (p. 368)

Logical, empiricist enquiry, then, is never pure; it always reaffirms the heart's impenetrability. Moreover, sentiments do not collapse the distance so much as they separate subjects--and subjects' emotionally charged bodies--into isolated individualism. As Tysdahl has argued, the sentimentalist. premises of The Man of Feeling are transmogrified into an individualism that is both empowering and frustrating. Both enquiry and affection yield no truth: rather, they point to the inability to overcome the inside/outside division.

In a sense, then, Fleetwood gets nowhere. By the last page of the novel he is still plagued by the solitude that he demonstrated in his relations with withers, and he still has no way to enter into and identify with someone else's subjectivity. The legitimation crisis of how to read the body has settled 
nothing, either by reason or by sentiment. It is in response to this familiar situation that Fleetwood undertakes yet another reading of physiognomy. After a protracted separation, he and Mary come together in the same room, and he declares:

Mary never looked half so beautiful, half so radiant, as now. Innocence is nothing, if it is merely innocence. It is guileless nature, when impleaded at a stern and inhuman bar, when dragged out to contumely and punishment, when lifting up its head in conscious honour, when Heaven itself seems to interpose to confound the malice of men, and declares, "This is the virtue that I approve!" there, there is presented to us the most ravishing spectacle that earth can boast. I never till now was sensible of half the merits of my wife. (pp. 370-371)

Here is the sentimental fallacy: unlike the judicial body of Gifford, Mary's domestic body externalizes the internal, and exposes the hidden. But what has preceded this in the novel should make us skeptical. Given the desperation by which Fleetwood has always seen what he wanted to see, given the novel's fascination with the problem of reading the body, given the disbelief in the outside as an unmediated testimony of the inside, this final flourish in not convincing as a reconciliation. What it does illustrate is the epistemology of the tortured body as it runs throughout the novel. Mary is deemed innocent because she looks innocent, and that very 
innocence requires for its extraction "contumely and punishment." Torture, as we have seen, is the invasion of a body whose interiority can never really be known by a reliable epistemological model. The only way to make that invasion effective is to sympathize with it while at the same time hurting it. It has been necessary that Fleetwood make Mary suffer, not so that he can sympathize with that suffering, as spierenburg would have it, but so that he can usurp it and make it part of his hermeneutic for reading the body. Enquiry cannot make him a fitting husband; nor can sentiment. Only through her pain which he assumes and supplants can he come to accept her innocence.

Painted by the false colours of the creative imagination, Mary's pain is the final demonstration of Fleetwood's isolation and empowerment in the novel. True, he does return to domesticity, but the relationshir carries with it the vestiges of Fleetwood's solipsistic subjectivity. Therefore, if there is a sentimentality and praise of domestic affection here, it is perverse and twisted. Hypostatized by the spectacle of pain, sentimentality charts the transference from the sentient body of the other to that of the self. And this transference allows a space for "knowing how you feel," a space that includes in some partial way both the tyrannical torturer and the sympathetic spectator.

When Martha informed Fleetwood that Gifford had been tortured, she unleashed in him a philoscphical diatribe. That 
diatribe ultimately outlined Fleetwood's protectionist individualism which remained immune to the politically tortured body: he felt no sympathy, no outrage. But Martha's information also did something else. Torture by the boots, as she relates it, is a "contrivance the French have to squeeze the truth out of a man" (emphasis added). In Martha's account, it is France that tortures, and France that is deemed barbarous. The assignation that torture is a French-or at least, Catholic-practice is common Gothic stock, as I have already indicated: indeed, the French torture Gifford here, Fleetwood tortures the dolls while he is in Italy, the French torture Jean D'Aunoy in Radcliffe's The Romance of the Forest, the sparish torture Ambrosio in The Monk, and the Italians torture Schedoni in Radcliffe's The Italian and Marzio in The Cenci. But what this heyday of literary torture suggests is not simply a facjle condemnation of Catholic countries in general, and France in this particular case. Literary torture as I have outlined it above actually invites an English audience to sympathize, but only so that, in sympathetic pain, it can return to its own protected, private, empowered body; it affirms for the spectator a kind of solitary confinement. Like so many other young radicals at the turn of the nineteenth century, Godwin lost faith in the French Revolution, and began to fear its influence. His depiction of torture argues a kind of asthetic protection against a creeping Catholic, francophile influence. He re-encloses the threatened English body. 
Notes

1.Matthew Gregory Lewis, "Mistrust, or Blanche and Osbright; A Feudal Romance," in Romantic Tales (London: Longman, Hurst, Rees, and orme, 1808), p. 45 .

2.Edward Peters, Torture (New York: Basil Blackwell, 1985), p. 74.

3. Discipline, p. 39 .

4. Torture, P. 1 .

5.Hanson discusses this problem in terms of an epistemology of "discovery" which sought to draw truth from the body, but which was troubled by the very truth it sought to draw. Since Renaissance torture was looking for confessions of treason that proceeded from a spiritual site which, by definition, could not be trusted, "every project of discovery, 'successful' or not, revealed the impenetrable sanctum it had created. Thus, the victim's positive sosertions of his truth were never treated as a discovery that he possessed no subversive secrets. ("Torture and Truth in Renaissance England," Representations 34 [1991], p. 77.)

6. The Spectacle of suffering, p. $x$.

7. They also appear in the criticism and commentary on that reform. Spierenburg's book sets out to correct Foucault's, which itself had wanted to demythologize the benevolent humanism which 
had proceeded from notions of enlightenment "progress."

8. And torture is a phenomenon in the Gothic novel. In fact, Godwin's is just one of some thirty Gothic novels produced between 1790 and 1830 in which scenes of torture figure prominently. For a complete list, see Ann B. Tracy, The Gothic Novel 1790-1830: Plot Summaries and Index to Motifs (Lexington: University of Kentucky Press, 1981). Tracy conveniently subdivides these novels into those dealing explicitly with torture, and those merely showing the instruments of torture or chambers.

9. The utterly barbarous countries of which Beccaria speaks are, for the Gothic novel, synonymous with Roman Catholic countries: Italy, Spain, and at times, France. By depicting torture as the state agent of Catholicism the Gothic novel, as Joel Porte argues, articulated a protestant suspicion of Catholicism's sinister influence on the continent, and helped to legitimize the strength of Protestantism in England ("In the Hand of an Angry God: Religious Terror in Gothic Fiction," in G. Richard Thompson (ed.), The Gothic Imagination: Essays in Dark Romanticism (Pullman, Wash.: Washington State Press, 1984, p. 43). By imagining another's pain, it could proclaim against the tyrannical source of that pain--Catholicism. The crowning irony of this suspicion of Catholic barbarity is that the British use of torture in the Renaissance was by Protestants trying to rout cut Catholic heretics and to check the spread of Catholicism. 
Therefore, the Gothic's use of torture to depict Catholic barbarity is a ludicrous projection of guilt.

10.Sir William Blackstone, Commentaries on the Laws of England, Vol. IV (New York: Garland, 1978), p. 326.

11.Quoted in Paolucci's Introduction to Beccaria, p. xxil. 12. Ibid., p. xxiii.

13. Sources of the self, p. 331 .

14.Jürgen Habermas, Communication and the Evolution of society, trans. Thomas McCarthy (Boston: Beacon, 1979).

15. Sentiment and sociability, p. 201

16.Percy Bysshe Shelley, Zastrozzi and st. Irvyne (New York: Oxford University Press, 1986), p. 5 .

17. Sade was one of the first to argue that the Gothic novel was an expression of European revolutionary unrest rather than conservative moralism. In Ideas on the Novel, he writes that the Gothic,

whatever may be said about it is undoubtedly not without merit. It was the inevitable fruit of the revolutionary shocks felt by the whole of Europe. For one who knew all the miseries with which the wicked can afflict humanity the novel became as difficult to create as it was monotonous to read. There was not a 
single individual who had not experienced more misfortune in four or five years than the novelist could paint in a century. (Selected Writings of de Sade, trans. Leonard de Saint-Yves [London: Peter Owen Limited, 1953], p. 287)

18. "Ereface," p. 240.

19.William Godwin, An Enquiry Concerning Political Justice an Its Influence on Modern Morals and Happiness (Markham, Ont.: Penguin, 1976), p. 631 .

20. Caleb Williams, p. xxv.

21.Mitzi Myers, "Godwin's Memoirs of Wollstonecraft: The Shaping of Self and subject," studies in Romanticism 20 (1981): p. 305 .

22. William Godwin, Travels of St. Leon (London: Henry Colburn and Richard Bentley, 1851), pp. ix-x.

23. William Godwin, Fleetwood; or, The New Man of Feeling (London: Richard Bentley, 1853).

\section{Moral Sentiments, p. 9 .}

25. Sade, in his 1791 Justine, posits in his creed of libertinism a rigorous and frighteningly convincing critique of the Moral Sense Philosopher's notion that pain can and should be shared. His character clement argues to the ingenuous Justine that Nature's primary law is to maximize pleasure and minimize pain. 
Pleasure is only achieved when the senses are given "all the irritation of which they are susceptible in order, by this means, better and nore warmly to reach the ultimate crisis . . . ." To attempt to share this pleasure is to divest it of its centrality. and to weaken it in ways contradictory to its nature. Then Clement adds somewhat of a nota bene that the desire to give someone else enjoyment is merely a matter of pride and selfflattery, with the same selfish end. And if you want to flatter your pride, furthermore, tyranny is much more effective than benevolence. Therefore, if concern for another's feelings is merely self-centered, we must conclude that, "in truth, there is no relation at all between that object [ie. a woman/lover/victim] and himself. He would be a fool to trouble himself about the object's sensations and forget his own . . . " see The Complete Justine, p. 604 .

26. Fleetwood's construction of Mary as theatrical piece makes this scene analogous to what Michael Fried calls an "absorptive tableau." An "absorptive tableau" is a certain mood in eighteenth-century French painting in which the spectator is simultaneously absorbed by the realism of the action on the canvas and made aware of his inability to enter that action. Thus, say John Bender, the absorptive tableau defines "a spectator who is at once isolated and irrevocably fascinated with the sensations and thoughts of the beings he confronts--a spectator simultaneously at one with an imagined consciousness yet incapable of direct entrance into its realm" (Imagining the 
Penitentiaryy, p. 232). This dialectic seems to me to characterize Fleetwood perfectly, except that the fascination and frustration of denied entrance are rendered all the more potent by his being the artist, the actual creator of the scene.

27.B.J. Tysdahl, Will liam Godwin as Novel ist (London: Athlone, $1981)$, p. 116 .

28. The privileging of mental sufferings over physical ones also

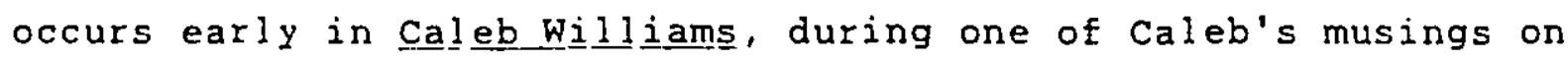
Falkland's power. As he fears the implications of Falkland's wrath, Caleb declares:

I envied the condemned wretch upon the scaffold. I envied the "ictim of the inquisition in the midst of his torture. They know what they have to suffer. I had only to imagine everything terrible, and then say, The fate reserved for me is worse than this! (p. 167.$)$

I suspect the torture victim himself would have a different opinion on what hurts more: mental or physical abuse.

29 . Body iㅡ Pain, p. 35 .

30. Angela Carter says something like this in her discussion of torture in Sade's Justine. She writes:

The heart's egoism sees itself suffering when it sees another suffering and so it learns sympathy, because it can put itself in another's place; then the heart comes 
a little way out of its egoism and tentatively encoun.ers the world. But, before the prospect of its own suffering, the heart melts completely and retreats into egoism, again, to protect itself. (The sadeian Woman and the Ideology of Pornography. [New York: Pantheon Books \{1978\}], p. 52.)

For Carter, or Carter's Sade, sympathy here is a moral failing. In my reading of the Gothic, the failure is more physiologically based.

31. The "boots" were metal footwear which could be tightened by driving wedges into the straps located between the boots and the victim's legs. When tightened, they crushed the shin bones. This "contrivance. . to squeeze the truth out of a man" is just one of a large lexicon of techniques which literalize the metaphor of "extracting" the tru:h from the body. For a more complete description of these techniques, see L.A. Parry, The History of Torture in England (New Jersey: Patterson Smith, 1975). 
Chapter Five:

Aesthetics and Anesthetics at the Revolution

In Canto $X$ of Don Juuㅡ, our hero is taken ill at Catherine the Great's court. Fearing he may die, Catherine summons a physician who applies rigorous doses of purgatives and emetics. The narrator reflects on this treatment as follows:

This is the way physicians mend or end us, secundum.artem. But although we sneer In health, when ill we call them to attend us Without the least propensity to jeer.1 As Byron well knew, we are extremely distrusteul of physicians. The medical care that Juan undergoes almost kills him, not unlike the treatment Byron received at Missolonghi. But Byron also points to what may be another source of this antimedical suspicion: we need the physician, and are forced to trust him, during times of ill-health. Sickness and its attendant pains disempower us, and the only hope for re-empowerment is to submit ourselves--not only bodily but incellectually as well--to the "expert" in bodily matters. In other words, physical reempowerment necessitates a further disempowerment, as we resign control of ourselves to the hands of another.

Questions of empowerment are ultimately political questions. Thus, the resignation of the individual to the physician has the overtones of a kind of tyranny. But as this passage from Don Juan points out, tl.s resignation is potentially liberating, and 
ultimately for our own good. Medicine's liberating potential was trumpeted at the end of the eighteenth century as perhaps at no other time. With a marked development in the theory and technology of healing, medicine offered a nouveau regime of personal and political empowerment through health, what Foucault would call a "master discourse." To ensure this new regime, doctors began to work together with governments to promote higher health standards, stricter regulations for care, and more humane surgical procedures.2 Ultimately, medicine took upon itself the task of liberating us from the most immediate of all tyrannies: our own pain. But as Byron knows, that liberation puts us in the ambiguous position of surrender--a doctor's scylla to pain's Charybdis. This ambivalence--the ownership of a painful body versus its resignation to medicine--constitutes a discomfort that pulses through the body of the revolution, and Romanticism's reaction to it.

In The Birth of the clinic, Foucault suggests an analogy between the medical revolution in France and the great Revolution of 1789, in that both movements looked toward the formulation of a perfect, pristine, healthy body--the individual body in the case of medicine, and the body politic in the case of France (p. 38). In The Body and the French Revolution, Dorinda Outram explores this analogy further, seeing changes in the medical systen as a necessary precondition for the events of 1789 Outram discusses how a changing conception of health attempted to 
wrest the image of the body from the monopoly that the monarchy had held over it (in the iconography of the sovereign body) and to centre it instead in the bodies of the middle-class ( $p .47$ ). Rather than concerning itself with the saving of souls, as the ancien regime had advocated in crder to regulate public behaviour, medicine began to look at saving bodies, bodies with an innate dignity regardless of class. ${ }^{3}$ (Obviously, the switch in emphasis from the King's body to the commoner's is the master trope by which the sans-culottes tried to empower the middle classes at the expense of monarchial rule.) with this restructuring of medical demographics came an emphatic dictum to assume personal responsibility for health, an imprecation to tend one's own garden through a regime of proper diet, exercise, temperance and abstinence. For Foucault, this regime was ultimately part of a capitalist strategy to police the circulation of foods, goods, utilities, and persons--anything that might spread disease and compromise personal/public health (p. 25). But for outram, this policing goes further than market. power struggles or the professionalization of health and its assumption of powers: for her it is a move toward the articulation of an entirely new, post-revolutionary citizen, one who managed his own affairs autonomously and individually, and whose physicality constructed a clear boundary around the self, yet who was also a "citízen," and whose personal health habits reflected and magnified a larger constitutional or contractual community. The concept of health, she argues, "entailed a 
reflexive idea of the individualized body: person, body, health and self-management were welded together in a way which separated each body from any other body" and in so doing, constituted the body politic (p. 48). This individuated citizen, this homo clausus, became the revolutionary ideal that embodied the contradictory needs of individual freedom and public identity ( $p$. $67)$.

Both Foucault and Outram are interested in (but not confined to) the social implications of this new bodily iconography, and how its audience came to view the body through revolutionary ideals. But, as I discussed in chapter one and as outram point:i out, there is also a democratizing going on "inside" the body in the way the entire nervous system was being re-mapped. The secularization of the body, she notes, changed the medical community's conception of how the human body received and responded to physical stimuli. I argued in chapter one that Robert whytt's "sentient principle" democratized the individual body by wresting it from Cartesian theories of sentience. For Whytt (and others like him, including John Hunter and Theophilf de Bordeu, in Montpelljer, Franced), all parts of the body contributed to one's sentient experience--be it pleasure or pain. By the end of the eighteenth century, the sentient principle had replaced--or serious challenged--the hierarchically structured image of the body as a mechanistic reflex, the model that Descartes had propounded. This sentience, moreover, was part of a large-scale movement to validate the "aesthetic" as that 
complex of physical sensations by which we move in and know the world. The aesthetic, what Alexander Baumgarten first named the myriad of physical responses we call experience, became the declaration of each person's connection to che material world. With the universal connection to the aesthetic came a universal dignity, in that each person had a natura 1 relation to nature, to others and to the self, a relation defined in the sinews of the body. With this sentient democratization, with this validation of aesthetics, the late eighteenth century effected at the individual level what the French Revolution would attempt to do at the political.

However, at the same time that the liberating potential of bodily sensation in the late eighteenth centuiy was validating physical sentience, it was also trying to avoid it. As I have also discussed earlier, sentience exists on a continuum: it need only be exaggerated a bit before it produces pain, the logical extension of sense perception. For Elaine scarry, this continuum creates a contradiction. On the one hand, pain is the most powerful confirmation of our existence we can imagine; it is the most "aesthetic" experience possible, if we take aesthetic in its original sense (p. 4). But on the other hand, pain breeds the monster that destroys itself, in that it threatens to destroy our awareness of it ( $p, 35$ ). Intense pain often becomes numbness (as in the shock that often follows a serious wound or violence) or induces unconsciousness. This continuum--or contradiction--in the nature of pain tends to confuse the heightened sense 
perception of aesthetics with the unperceiving state of anesthetics. The two risk becoming the same thing. And at the end of the eighteenth century, the age of the aesthetic par excellence, this confused relation became all the more acute.

It is not surprising, then, that with the validation of aesthetics and the individuation of feeling in the late eighteenth century came a concerted movement on the part of physicians to control the medical experience of pain. As surgical practices became more sophisticated and more widespread, so did physicians' and surgeons' sensitivity to the pain they were inflicting on their patients. By the 1750 s, the man of feeling had truly entered the operating room.s And with him came the development of anesthetics. When Joseph Priestley discovered in 1776 that gaseous nitrous oxide could be absorbed immediately into the lungs, rather than being ingested through the stomach, he paved the way for Humphrey Davy so suggest in 1800 that this "laughing gas" could be an effective anesthetic.6 Until Priestley's discovery, opium had been the major analgesic in surgery. But opium is ineffective, addictive, and nauseating in large doses, as Coleridge and Thomas De Quincey knew all too well. In fact, opium became so discredited as a pain killer that it soon became associated with quackery, witchcraft, and black magic.7 Nitrous oxide, finally used in 1844, reduced the unpleasant effects of narcotics at the same time that it reduced pain, and thereby replaced morphine, first used in 1803 , as the most popular form of anesthesia.8 This tenuous experimentation 
with anesthetics reflected a change in the entire definition of "anesthetics" changed in the eighteenth century. In the early 1700s, "anesthetic" had meant a defect or lack of feeling, following its direct translation "without feeling" (OED). However, by the end of the century, "anesthetic" became a positive medical relieving of feeling, a blessing rather than a defect. This connotative shift put the whole status of physical sentience in the strange position of being validated and attacked at the same time, a position that, as we shall see, is documented in the fictions of pain.

If sentience is indissolubly associated with revolutionary freedom, yet is at the same time feared and suppressed, then anesthesia also becomes an ambivalent agent. It can either be a condemnable suppression of liberating aesthetics, or a liberation from the tyranny of pain. In the discussion that follows, I want to suggest that anesthesia in the late eighteenth century signifies a complex of attitudes that ties together feeling, medicine, and revolution, and that this complex runs throughout a number of turn-of-the-century texts. Edmund Burke's Reflections on the Revolution in France, Matthew Lewis's The Monk, and Byron's comic-epic Don Juan, all use the image of the anesthetized body to discuss revolution. This anesthetized body simultaneously evokes a liberated, unfettered self, and a self whose political materiality is compromised by the experience of anesthesia. What will emerge from this discussion is a Romantic 
"politics of pain," a definition of one's relation to one's own painful body and the more general body politic.

I I

The clearest articulation of ambivalence regarding feesing and anesthesia comes from Priestley's famous adversary Edmund Burke, in his Reflections on the Revolution in France. Here, Burke uses the image of the body to refer to its familiar metaphorical analogue, the body politic. According to David George Hale, the image of the body politic had moved from the pre-modern symbol of organic unity and wholeness through the Civil War to being synonymous with the state, a group of individuals bound together by social contract.9 In a way, this development is precisely the one that troubles Burke. In the Reflections Burke tells his French correspondent de Pont that France is "bound, in all honest policy, to provide a permanent body, in which that spirit [of rational liberty] may reside, and an effectual organ, by which it may act. . ." (p. 85). But liberty for Burke must be circumscribed and controlled, because "liberty, when men act in bodies, is power" (p. 91), and it is precisely the usurpation and misuse of power that Burke attacks in th" French Revolution. The need for a strong political body, yet the fear of what this body can do (and will do, given that Burke's Reflections actually predicts the regicide and Reign of Terror to follow) lead him to nostalgia for an organic body politic, "a permanent body composed of transitory parts" ( $p$. 120), one that allows for evolving differences in class, 
political opinion, and economic policy, but that respects the overall stability of tradition, property, and religion. Both in the Re ections and in the Letter to a Member of the National. Assembly. Burke emphasizes the importance of political wholeness, and of the constituent parts submitting to a larger unifying principle. In other words, Burke envisions an ideal body politic as vigorous, healthy, and active in all its parts, but like the earlier ideal, one that is ruled by the mind, that unites its discord into the concord of a central, monarchial reason.10

But for Burke, the French body is not behaving as it should. Its members have assumed a power for themselves that contradicts the central authority of the mind. The body of France is diseased. As James T. Boulton has pointed out, Burke figures revoiutionary power as illness: the body of France has been attacked by a virulent, infectious disease that Burke fears will spread to England through an "epidemical fanaticism."1 Confusion in France, Burke says, is "like a palsy, [which] has attacked the foundation of life itself" (p. 137); it is a "plague" (p. 185), a "disease" or "distemper" (p. 116). While Gary Kelly reads this distemper as a literal dis/temper, a lack of psychological balance that results in madness, it is also distemper in the sense of physical disorder, of disease. And like an animal distemper, this disease is contagious:

Formerly your affairs were your own concern only... [Now they] are part of our interest; so far at least as to keep at a distance your panacea, or your plague. If 
it be a panacea, we do not want it. We know the consequences of unnecessary physic. If it be a plague, it is such a plague, that the precautions of the most severe quarantine ought to be established against it.

(p. 185 )

Leaving aside momentarily Burke's interesting conflation of "panacea" and "plague," I want to emphasize the contribution this passage makes to the fear of physicality in the Reflections. For the English conservative, France's efforts at democracy have evinced an entire collapse of humanism's structuring principle: they have privileged the irrational and unwieldy parts of the body, the "moral and almost physical inaptitude" of the incompetent revolutionaries (p. 134) over the divinely ordained principle of reason. The body--through its disease--has stormed the bastion of reason, overturned the monarchy, and imprisoned the soul.

While Burke abhors the disease that has attacked France, he detests more its methods, and the ways in which it justifies itself. For Burke, the treatment is an even greater travesty than the disease. This treatment, naturally, continues the strain of what I am calling the antimedical prejudice in the eighteenth century and beyond. In Burke's early following of events in France, 12 he was surprised to find that a great proportion of the National Assembly were "practitioners of the law," but "the inferior, unlearned, mechanical, merely instrumental members of the profession" (p. 130). Now, if this 
weren't bad enough, this "handful of country clowns" (p. 131) had taken up with a group of lower-level physicians: "To the faculty of law was joined a pretty considerable proportion of the faculty of medicine" (pp. 131-2). And this is a prescription for disaster. In a line which anticipates Nietzsche's Genealogy of Morals, Burke complains that "the sides of sick beds are not the academies for forming statesmen and legislators" (p. 132). By promising a "constitution" and "natural rights," France has privileged the diseased body over the monarchial one. And in so doing, France's leaders "have seen the medicine of the state corrupted into its poison" (p. 126). Like the famous phajinakon in Derrida's analysis of Plato's Phaedrus,13 the poison and the cure are collapsed into each other through France's specious political policies. The hopeful panacea has become indistinguishable from the plague.

Promoting the status of physicians and disease over the wisdom of high-born elder statesmen has dire political consequences. Burke writes:

I never liked this continual talk of resistance and revolution, or the practice of making the extreme medicine of the constitution its daily bread. It renders the habit of society dangerously valetudinary: it is taking periodical doses of mercury sublimate, and swallowing down repeated provocatives of cantharides to our love of liberty. This distemper of remedy, grown habitual, relaxes and wears out, by a vulgar and 
prostituted use, the spring of that spirit which is to be exerted on great occasions. (p. 154)

Burke's pharmacology here is complex. Mercury sublimate was a purgative used to promote the flow of bile, as well as to treat infection and syphilis. Cantharides were made from an extract of the spanish fly, and we know what that promotes. Both drugs are stimulants, meant to excite the patient--in this case, French revolutionaries and Jacobin sympathizers--into high levels of physiological and metabolic activity. Indeed in Burke's passage, this activity is sexual as well as mediciral. But the effect, Burke reasons, is quite the opposite. Aphrodisiacs are a vulgar, prostituted use of sexual energy, and all that arousing and purging is ultimately exhausting. By invoking too much excitement, too much stimulation, France risks relaxing and wearing out the spirit of reason and prudence that it needs to manage its affairs properly. And having worn out this spirit through overuse, it is in the position of being no longer able to diagnose its own condition; it does not know how sick il really is. In effect, excessive stimulation leads to a kind of numbing. stimulants become anesthetics.

The problem with France, then, is that too much feeling often creates too little. Moreover, this tendency for stimulation to anesthetize itself is not a mere symptom of the disease, it is one of its causes. By dousing itself with drugs, France is perpetuating its illness. The promise of democratic reform may be the spoonful of sugar that helps the medicine go 
down, but for Burke, "The anodyne draught of oblivion, thus drugged, is well calculated to preserve a galling wakefulness, and to feed the living ulcer of a corroding memory" (p. 163). Excitement, stimulation, an excess of the revolutionary aesthetic produce anesthesia, and beneath the numbness of the diseased body an ulcerous illness continues to rage. For Burke, joining medicine to the National Assembly is a sure way to destroy the moral order. The relief from pain which characterized the democratic movement in medicine--and upon which a whole new medical discourse of freedom was based--is here a dangerous sedative that makes the patient worse instead of better.

Burke's critique of anesthetics implicitly suggests that pain can be an effective teaching tool, that there is a diagnostic value in the ability to hurt. That value, of course, is in the ability of the physician (in this case, the Tory parliamentarian) to isolate and identify exactly what the illness is, so that he can treat it more effectively. In a situation where there seems to be no hope for improvement, where the future is as bleak as the past--"in that lamentable condition," Burke writes, "the nature of the disease is to indicate the remedy to those whom nature has qualified to administer in extremities this critical, ambiguous, bitter portion to a distempered state" (p. 116). Elsewhere in the Reflections, those whom nature has qualified are those who "are not repelled through a fastidicus delicacy. . . from the medicinal attention to [the] menta] blotches and running sores" 
of the ignorant pagans or the swirish multitude (pp. 200-201). We must meet illness head on, without the obfuscation of painkillers or stimulants. Thus, in Burke's own way he necessitates the presence and privilege of the diseased and painful body over the anesthetized one: because that is the only body that can be treated directly and effectively; in the terms of contemporary health discourse, no pain no gain. And so, there is a crowning irony in the praise of one of Burke's greatest supporters, Edward Gibbon, who called Burke's conservatism (under the guise of 'chivalry') "A most admirable medicine against the French disease."14 In describing the medicinal value of the Reflections, Gibbon uses as encomium the image Burke seems most. to suspect. Anc, as we shall see in the Gothicism of Matthew Lewis, Burke could have had the effect of inoculating the English public against French influence but, by the time Byron addresses the issue, Burke's prescription takes on a medicinal value in exactly the way he hoped he wouldn't.

I I

Near the end of Matthew Lewis's The Monk, the distressed damsel Antonia reports seeing her mother's ghost. A physician is consulted regarding her health, and gives the following diagnosis:

He said, that to keep her quiet was all that was necessary; and He ordered a medicine to be prepared which would tranquillize her nerves, and procure her that repose, which at presert she much wanted.1s 
Unknown to the physician, his tranquillizing medicine is being supplemented by a "soporific draught" administered by Ambrosio, the novel's villain (p. 329). With designs of carrying her off to a dungeon for his sexual pleasure, Ambrosio secretly gives her the "juice extracted from certain herbs" which augments the physician's sedative and anesthetizes Antonia into a state resembling death. By virtue of this prescription, Ambrosio effects her rape and eventual murder. This scene-the epitome of tyranny in The Monk--centers on the combined forces of lust in the tyrant and anesthesia in the victim.

The crime committed against Antonia is analogous to the crime which the French Revolutionaries, according to Burke, had perpetrated against Marie Antoinette: both Ambrosio and the sansculottes penetrate the sacred lady's bed-chamber with the intent of penetrating the sacred lady (Ambrosio with his sex, the citizens with their sabers). As Ronald Paulson has argued, The Monk is typical of that ambivalence so common to writers of the latter half of the 1790s. Ambrosio's sexual liberation from the oppressive regime of the Catholic church itself becomes oppressive, as he victimizes the symbol of all that is good and true, the virginal Antonia. So while we may applaud his transgression against authority, we recoil at his violent excesses.16 But what Lewis also points to here, besides a straight-forward victimization by tyranny, is the role that anesthesia plays in perpetuating this tyranny: sedatives predispose Antonia to greater vulnerability and assist Ambrosio 
in his deeds. This anesthesia, I want to suggest, is similar to that in Burke, for whom anesthesia acted as a metaphor for the numbing excesses of the Revolution. In the antijacobin Gothic The Monk, anesthesia plays a literal role in the moral destruction which Burke had most feared.

Just as Antonia is victimized by tranquilizers which diminish her control over her body, so is Ambrosio affected by pharmaceutical prescriptions. Early in the novel, Matilda declares her love for him. Although he is sexually excited by this proclamation, he checks his bodily desires and declares that Matilda must leave the convent. (of such self-control Burke would approve.) However, at the moment he picks a rose for her-a moment whose allegorical significance is difficult to miss--he is stung by a deadly insect. Poison fills his veins and he falls unconscious. Father pablos, the attending physician, declares:

He cannot recover; . . All that I can do is to supply such herbs to the wound, as will relieve the anguish: The Patient will be restored to his senses; But the venom will corrupt the whole mass of his blood, and in three days He will exist no longer. (p. 72) Like the body politic in France, the body of Ambrosio has been infected with a poison, which is transparently linked to the poison of desire, and there seems little hope of recovery.

While the allegory seems clumsy here, the medical treatment that Ambrosio receives is more complexly allusive. In Burke's critique of the Revolution, the promise of reform became an 
anodyne that actually contributed to the disease; the panacea furthered the plague. The same suspicion of anesthesia pervades The Monk. Ambrosio is given pain-killers that "restored him to life, but not to his senses..." (p. 72); he regains consciousness, but not good judgment. When he miracuicusly rallies (for Matilda has sucked the poison from the wound), he is immediately administered a "strengthening medicine" ( $p$. 73), a provocative that, like cantharides in Burke's depiction of the Revolution, is intended to counteract the previously prescribed sedatives by invigorating the patient. As he rests, Matilda attempts to soothe him with her lute, but then to arouse him with her beauty--again making the analogy between sexual pas'sion and chemical stimulation. This combination of drugs is important to Ambrosio's behavior. He "was conscious that in the present disposition of his mind, avoiding her society was his only refuge from the power of this enchanting woman" (p. 82). The "present disposition" here is of a mind first diseased with "poison," then anesthetized by pain-killers, then invigorated with provocatives, then numbed again, then aroused by lust. Like the Revolutionaries, Ambrosio is numoed and aroused, aestheticized and anestheticized, into a "thousand contending passions" ( $p$. 83). It is these passions, I believe, that wreak as much havoc on his moral health as they did on the health of France.

The final result of the passions is that Ambrosio breaks his own resolution and allows Matilda to stay in the convent. This 
is his big mistake. Matilda's presence ultimately allows Ambrosio, in his heightened/weakened state, to entertain more sexual thoughts of her. When he finds out that she vampirized his wound, and that she is "dying" for him from the same poison, he falls into her arms, and begins a life of dissipation that will result in rape and murder. It is not the insect's venom that corrupts his blood, then, but rather the treatment, the anesthesia, that furthers the condition of a blood already tainted. And this anesthetic treatment helps to collapse Matilda's "cure" into Ambrosio's illness, so that panacea and nlague again become the same thing. As Burke had warned, the physical disempowerment that results from anodynes and provocatives helps to destroy the moral order.

Ambrosio's poison--both his lust and his disease--and Ambrosio's treatment--both pain-killers and provocatives--weaken his moral will and lead him to ruin; in Burke's words, they wear out "the spring of that spirit which is exerted on great occasions" (p. 154). Interestingly, pain-killers are used elsewhere in the novel, in the Bleeding Nun episode, but with surprisingly different effects. Just as Ambrosio entertains a passion for Antoria, so does Don Raymond attempt to win Agnes. And just as Ambrosio was wounded in the courtship, so is Raymond: while escaping with the woman he believes to be Agnes, he crashes his carriage and suffers two broken ribs, a dislocated shoulder, and a shattered leg. Furthermore, he is emotionally assaulted by the mysterious disappearance of Agnes from the crash site. Like 
Antonia and Ambrosio, he is ordered to swallow a "composing medicine" and to rest ( $P$. 159), but unlike the other two patients, Raymond reccives no comfort from the anodynes:

That repose I wooed in vain. The agitation of my bosom chased away sleep. Restless in my mind, in spite of the fatigue of my body I continued to toss about from side to side... . (p. 159)

Raymond's physical condition degenerates further as he is haunted by the Bleeding Nun. The physician continues to prescribe medicines that, Raymond says, "in some degree tranquillized my spirits," but "My fever seemed rather augmented than diminished; The agitation of my mind impeded my bones from knitting. . ." (p. 161). Unlike Ambrosio, Raymond is impervious to the effects of anesthetics; rather than allowing himself to be numbed--both physically and morally--by pain-killers, he remains fully conscious of the agitated state of his mind and the fractured state of his body. The healing must come from elsewhere.

Both Raymond and Ambrosio are slow to recuperate because of their excessive passions. But it is the source of these passions that marks the distinction between the two. Raymond refuses to heal because he is being haunted by a ghost. That ghost is initially thought to be superstition and hypochondria, which can easily be driven out by proper treatments. But the point of the Bleeding Nun episode is not superstition. Rather, we learn that Beatrice, the spectral Nun, is an ancient relative of Don Raymond who had abandoned herself to a scandalous passion for Baron 
Lindenberg. With all the behaviour unbecoming to a lady of her class, she had displayed "the incontinence of a prostitute" and "confessed herself an atheist" (p. 173). In her dissipation she joined with the Baron's younger brother otto in murdering the Baron so ihat he couid "make himself Master of the Castle" ( $p$. 174). She is then murdered as well, and her restless spirit roams the earth. As the source of Raymond's illness, Beatrice suggests not merely superstition or even illicit passion (although she is all of these things), but rather usurpation, the improper seizing of $l$ and and property rights. The seizures affecting Raymond are not only medical but manorial as well; it is the usurpation of legitimate authority as embodied in the holding of property that is fragmenting the aristocratic body.

The ghost of Beatrice and its effect on Raymond's illness have, I would suggest, revolutionary overtones. In Burke's Reflections, he charges de Pont with excessive concern for ghosts of the ancien regime to the neglect of property, which the Revolutionaries are seizing indiscriminately: "You are terrifying yourself with ghosts and apparitions, whilst your house is the haunt of robbers" (p. 248). In fact, Burke's primary concern with the Revolution is that it represents the overthrow of the landed classes. This misuse of property, this French disease, is what haunts Don Raymond, and no amount of opiate or anesthetic can obliterate its importance. Significantly, then, to heal the rupture in property is to heal the human body as well. As soon as Raymond learns the true natu of the Nun's mission, he buries 
her bones and thereby returns to the new Baron his rightful ownership of the estate he has inherited. He cures the fractured social body of iis revolutionary usurpation. And with the reinstituting of property rights and class privilege comes Raymond's medical report that "From this period I recovered my health so rapidly as to astonish my Physicians" (p. 177).

Personal health here is, as in Burke's Reflections, analogous to the reinstatement of landed succession, the re-empowerment of ihe aristocracy away from the tyrannical revolutionaries who steal power (or, in the case of Beatrice, those who transgress the demands of their class). The nature of the disease, as Burke had written, has dictated the curo.

In The Monk, then, pait and anesthesia are remarkably classbound. Raymond's body refuses to accept the "anodyne draught of oblivion" that had made the moral order sick instead of better; rather, as Burke had implied, sain is necessary for the aristocrat to get to the heart of social decay. But not so for those outside the aristocracy. Significantly, Ambrosio numbs himself to his own illness so that that illness can continue to rage. As Daniel P. Watkins has pointed out, Ambrosio is the p: oduct of a cross-class liaison that the novel explicitly condemns.17 His mother, Elvira, was a shoemaker's daughter who had disregarded her station by marrying a spanish nobleman. The unfortunate product of this marriage, Ambrosio, was immediately placed in a monastery where he was forced to repress his bodily desires--a repression that, paradoxically, strengthened them all 
the more. Thus, with the repression of physicality enhanced by anodynes, with the aesthetic numbed by the anesthetic, Ambrosio becomes the revolutionary par excellence. His inability to feel his own bodily sensations leads to his inability to control them, and like the tyrannical mob at the end of the novel--indeed, like Burke's notorious "swinish multitude"--he loses control.

Underneath the anodynes the "galling wakefulness" continues to corrode him, and he finally explodes in revolutionary violence and tyranny. Physical anesthesia ultimately denotes moral anesthesia, and the result is political disaster.

Anesthetics are feared in Gothic fiction, then, because they remove the diseased body from its dialogue with the mind; they disturb the natural sympathy that Robert whyt had argued was the basis of all behaviour. But the social implications of Whytt's aesthetic go even further. The "remarkable sympathy - . between various parts of the body" that whyt had observed was also the basis for the still more wonderful sympathy between the nervous systems of different persons" that connected people in physical fellow-feeling; in whytt, the sympathetic

transmission of pain is what makes social community possible. In The Monk, this transmission further marks the class distinctions of pain. As a murderous tyrant, Ambrosio is unable to feel another's pain: he sentences Agnes to the dungeon, murders Elvira, and stabs Antonia--all for his own protection. His own passions anesthetize him to others. The aristocratic Don 
Lorenzo, on the other hand, exemplifies what whytt described as the sympathetic trans er of morbid symptoms. As he comes upon his sister Agnes in the dungeon, he dces not recognize her, but Lorenzo stopped: He was petrified with horror. He gazed upon the miserable object with disgust and pity. He trembled at the spectacle; He grew sick at heart: H s strength failed him, and his limbs were unable to support his weight. He was obliged to lean against the low wall which was near him, unable to go forward, or to address the sufferer. (p. 369)

Like Raymond, Lorenzo here has an intensely aesthetic experience, one that feels pain fully. But here, that pain is another's. The benevolent Lorenzo shared a community of pain in the kind of scene that is never afforded to the lower classes in the novel. Not only does pain connect the aristocrat's body to his own mind, as it did with Raymond, but it also re-unites him with the subjective spaces of others. Pain ultimately heals the fractured body, and the fractured body politic.

Through its exploration of the dangerous cerrain of aesthetics and anesthetics, The Monk gives us a political directive for our relationship to pain--both in the lext and in ourselves. When we read of Raymond's broken legs or Ambrosio's brutal violences, when we find Agnes chained in her dungeon, we are intended to feel at some level the physicality of their bodies; we are invited to make their aesthetic our own. Because of this, the Gothic has traditionally been defined as a series of 
extremely violent episodes that, while iniending to invigorate us, most often end up boring--shall we say, anesthetizing?--us . But the situation is more complex. What we see in Lewis's novel is a fear of the social catastrophe that results when bodies are numbed to their own pain. And in this sense, Lewis translates Burke's antimedical prejudice into a fictional account of antirevolutionary politics. But we also see in the praise of pain an aristocratic virtue that redefines our relationship to our own pain and the pain of others. The aesthetic of pain in this novel is meant to re-acquaint us with a fractured body politic, and to seek in that fracturing what Burke called a "whole, composed of transitory parts." Thus the feeling of pain here acts not as disease but as inoculation, an active resistance to the disease of the French Revolution. Burke's ultimate fear, we remember, is that the contagious revolutionary passion would spread to England. The Gothic, to the degree that it is antijacobin, anesthetizes our sympathies against this threatening infection. Like Raymond and Lorenzo, we are granted a modicum of pain; yet the pain we feel is just enough to make us believe that the illness, the real source of pain, is other, safely distant, and quarantined.

The Monk's attempt to validate pain may have more at stake than just the body politic; it may also be directed at Lewis's own body. Matthew Lewis was acutely familiar with pain. In a letter to his mother of 14 August 1804 , he describes the day's headache as "cne of my oldest companions," and indeed it seemed 
to plague him chronically.18 As well, he complained of a sore leg which troubled him when he walked, at one point diagnosing it as an attack of the gout.19 Finally, his whole body composition, "Of giaceless form and dwarfish stature" as he tells us in the Preface to The Monk (p. 4), and severely bothered by myopia of which he often complained, doubtless rendered Matthew Lewis's body a site of limitation, confinement, and compromise. Like the Gothic victim, whose pain is agonizingly immediate ard present, Lewis's body continually signified antagonism. But like the aristocracy in the novel, an aristocracy to which Lewis had pretensions, 20 pain can be a confirmation of sensibility and good breeding. Pain affirms not only the life of the body, but also the life of the mind that constantly recognizes its association with the body.

IV

The intimate relationship between personal pain and literary production also informs the work of Byron, Lewis's personal friend. For Byron, The Monk was an admirable piece of reading, but its worst sections were like "the philtred ideas of a jaded voluptuary. . . They have no nature--all the sour cream of cantharides."2l That Byron should condemn Lewis's style on the basis of its artificial stimulation is paradoxical to say the least: according to Leslie Marchand, Byron himself turned to reading literature as a way of escaping his own medical problems, to wit, the pain in his right foot.22 and if Gothic excess is a stimulant leading to anesthesia, as we have seen in Lewis through 
Burke, then for Byron the whole world of aesthetics (in the literary sense) is an escape from aesthetics (in the original, ontological sense). Art is anesthesia. This problem is redoubled when Byron reads--and eventually writes--his revolutionary literature, for it raises questions of how he figures the complex continuum of pain in artistic production that is itself haunted by the binarism of aesthetics and anesthetics. If the act of writing is a "torture" and composition a "great pain," as he metaphorically describes it,23 tien how does such physical pain come to be depicted within the anesthetizing agency of literature?

Like Terry Eagleton's definition of aesthetics, Byron's was born as a discourse of the body. His ambivalence toward feeling and anesthesia has a long psychological history. Like Matthew Lewis, Byron himself was constantly tormented by his own body and medical attempts to treat it. The pain in his right foot--a pain that tormented him all his life--proceeded frorl a deformity that he had reason to believe was not inevitable. At his birth, the attending physician John Hunter pronounced that the deformity could not be cured; it could merely be treater with the ri, ht prosthetic shoe. 24 However, eleven years later, on $17 \mathrm{July} 1799$, the young Byron was told by Dr. Baillie that proper treatment in infancy might have corrected the malformation and relieved the child from years of pain.23 whether Baillip was right or not, Byron must have resented tise los $c$ opportunity for a cure, and this resentment flowed from his pen almost every time he 
portrayed the medical profession. But more than just creating-or deepening--an antimedical prejudice, Byron's relations with doctors confirmed for him a life of antagonism against his body. In fact, Byron once claimed to have gone to London, probably during his school days at harrow, to have the foot amputated, but the surgeon refused to perform the operation.26 Byron's foot, coupled with his perpetual weight problem, haemorrhoids, his numerous fevers and catarrhs, all bespoke an awareness of the body as tyrant, a body whose limitations, like Manfred's or Arnold's in The Deformed. Transformed, constantly reminded him of the Faustian boundaries of living "coop'd in clay."27 Byron once confided to Francis Hodgson a rather pathetic wish: "let me live well, if possible, and die without pain."28

Yet if the body always represented for Byron tyrannic pain and limitation (as it did for Lewis), it was also the site of his most pleasurable transgressions. His sexual exploits are recorded in both Leslie Marchand's biography of Byron and his compilation of the letters and journals, making them too well known to require listing. These sexual exploits were, for Byron, part of a larger critique of an ancien regime of Calvinist metaphysicians and moralists who advocated temperance and modesty as a way to health. "I shall not live long," he wrote to Hobhouse and Kinnard on 19 January 1819, "\& for that Reason--I must live while I can. . . ."29 And if the narrator of Don Juan is to ze trusted, a life of sexual dissipation is a means to health, far more effective than anything a doctor could 
prescribe. The narrator recounts the story of King David whom sex cured of illness:

' Tis written in the Hebrew chronicle

How the physicians, leaving pill and potion, Prescribed by way of blister a young belle, When old King David's blood grew dull in motion, And that the medicine answered very well.

$$
(1,168,2-6)
$$

Health depends upon exercising the body in every way, avoiding none of the pleasures of the voluptuary. Like Lewis, for whom the body represented the possibility for fulfillment and community (as well as sexual transgression in The Monk), so for Byron did physical stimulation validate his sense of being in the world. As Jerome McGann writes, Byron's early life was dedicated to "instant sensations and feelings (whether of pleasure or pain makes no difference)."30 His body was the central source from which he could live a commitment to individual pleasure, and to his definition of freedom.

It takes little effort, then, to read Byron's bodily ambivalence in pulicical terms. His dedication to a life of freedom and his loathing of any tyrannical description of his body echo his dreams of an emancipated Republic, dreams which, according to Daniel P. Watkins had become his primary fixation by 1821.31 Such dreams expressed themselves in his fantasy of a liberated Italy, about which he wrote to Augusta in a letter of 18 February 1821, in his praise of America in "Detached Thoughts 
112," and in his willingness to volunteer in the fight for Greek emancipation, a political commitment that finally destroyed his health and his life. For Byron, the physical body was not a metaphor for vague political principles, but rather the site at which political principles could be expressed. As Morse Peckham writes, Byron shared with the Marquis de Sade an overtly political. sexuality, in that "both of them.. . show the symbolic connection between sexual transgression and moral freedom."32 To exercise undue regulation over either the sexual body or the body politic is to submit each to an unnatural and immoral governance.

But while Byron's sexual transgression may ostensibly be part of an antiauthoritarian project, his body, by his own admission, is a problematic site for this agenda. As Edward Bostetter has argued, Byron's coterminous proclamation of physical freedom and enslavement underlies a larger ambivalence Byron felt toward the politics of his own body: Byron, says Bostetter, both indulged and cultivated his sexual passion (with a good deal of polymorphous perversity) as a means of living freely, and also hated and feared those passions as a threat to his will and independence. ${ }^{33}$ The powerful body can be both liberating and tyrannical--in much the same way that the Revolutionary mob can spawn the Reign of Terror. Just as Byron was suspicious of his own passions, so did he doubt the ability of any political interest--like Napoleon ${ }^{3}$ or the French mob--to gain power without being corrupted by it. Byron's dually 
liberating and tyrannical body, then, encapsulates a respect and fear of the body politic that Byron was exploring as he devoted himself simultaneously to the war for Greek imancipation and to the writing of Don Juan. In Canto VIII, Byron's most famous sustained treatment of revolutionary war, he presents the ambiguities posed by the sentient body in its political manifestations. This ambiguity fashions an aesthetic of revolutionary freedom as one which critiques its own tendencies toward anesthesia, tendencies we saw operating in Burke's ominous warnings and Lewis's fictionalized reflections.

In Burke's thinking about events in France, medical stimulants metaphorically represented the "continual talk of resistance and revolution" which, in Lewis's Gothic sensibility took on the characteristics of passionate excess and sexual transgression. In Canto VIII of Don Juan, Byron picks up this imagery but resituates it.33 As the siege of Ismail begins, Three hurdred cannon threw up theis emetic, And thirty thousand muskets flung their pilis Like hail to make a bloody diuretic. (VIII 12,1-3) Whereas for Burke, the excessive physical stimulation of war was in the discursive effects of debate and propaganda--what Byron detests as "cant"--for Byron the horror of war is precisely in its materiality, in the flesh-and-blood presence of battle. No amount of debate and speculation over plagues, famines, and physicians, he says, can compare "[t]u the true portrait of one battlefield" (VIII $12,7-8$ ). By situating medical imagery not as 
a problem of discourse but as one of material experience, Byron foregrounds the immediacy of physical pain, and in so doing, combines in Canto VIII the ontological aesthetic of pain with its literary aesthetic. The battlefield becomes the site of the most intense aesthetic possible, where the fear of war, "like wind/ Trouble[s] heroic stomachs" (VIII 40,4-5) and sets both soldier and reader within the aesthetic of potential pain.

But while the bloody diuretic of war foregrounds the aesthetic immediacy of human pain, so does it threaten to swallow up that immediacy. Byron's depiction of the seige occupies that liminal space that excess creates between physical horror and numbness, between the shocking experience of pain and the inability to feel it. Put another way, the aesthetic of war deconstructs itself, as its sensory elements degenerate into a confusion that obliterates them:

The very cannon, deafened by the dir, Grew dumb, for you might almost hear a linnet As soon as thunder 'midst the general noise of human nature's agonizing voice. (VIII 59,5-8) This revolutionary excess obscures the boundaries of all natural objects so that "the heat/ of carnage, like the Nile's sun-sodden slime,/ Engender[s] monstrous shapes of every crime" (VIII 82,58). As Ronald Paulson has argued, repzesentations of revolution in Romantic fiction often return to the imagery of Burke's sublime-- of the fearfully amorphous and monstrous--and push those images into the exaggeration of the grotesque (p. 171). This 
amorphousness or sense of the monstrous includes, of course, people: we are told that "three thousand Moslems perishrd nere" (VIII 81,7 ) in a magnitude of death that remains incomprehensible to the spectator. Such is the effect on Juan. 'ihroughout the seige, he moves through a heap of dead bodies without being the least effected. He can stumble "backwards o'er/ A wounded comrade, sprawling in his gore" (VIII 20,7-8), and not "care a pinch of snuff about his corps," "the greater part of which were corses" (VIII 30-3I). Thus, war and widespread carnage have that anesthetizing effect that Burke and Lewis describe: they create a vortex into which is sucked all sense of the other, as the most powerful of aesthetic experiences anesthetizes the perceiver. Yet, at the same time that the magnitude of the carnage threatens to obliterate all perception of the other, it also provides moments of sympathetic identification with that other. Juan can scramble over corpses wichout carilg a pinch, but

At a distance

He hated cruelty as all men hate Blood, until heated, and even then his own At times would curdle o'er some heavy groan. (VIII 55,

Indeed, Juan is capable of moments of extreme pity--as in the scene with the young Turkish girl (VIII 9i-iUI) or the valiant father fighting with his sons (VIII 116)--because soldiers, in Byron's view, are a "mixture of wild beasis and demigods/. . . now furious as the sweeping wave,/ Now moved with pity" (VIII 
$106,4-6)$. We see here what Frederick Garber describes as the central problem of individualism in the Romantic hero: a figure who wants to be alone, transgressive and individualist always finds himself compromised by a vestigial desire to fill social responsibilities. He is plagued by his own moral goodress.36 But Byron's depiction of this vicissitude is not merely intended to riake a general point about human nature or the Romantic hero. He also uses it to contrast the complete lack of sympathetic potential in the sovereignty and the aristocracy. General Markow, for instance, insists on removing and protecting the prince "[a]midst some groaning thousands dying near--/ All common fellows, who might writhe and wince/ And shriek for water into a deaf ear" (VIII 11,3-5). Whereas Burke and Lewis attribute sympathy only to the aristocracy, Byron dispels such a myth by allowing sympathy--however inconsistent--in the soldier classes. In fact, the aristocracy in Byron, like the mob in Burke and Lewis, is incapable of feeling its own pain:

The Prince de Ligne was wounded in the knee.

Count Chapeau-Bras [was hit by] a ball between

His cap and head, which proves the head to be Aristocratic as was ever seen, because it then received no injury More than the cap; in fact the ball could mean No harm unto a right legitimate head. 'Ashes to ashes'--why nct lead to lead? (VIII 10, 1-8) 
General Markow is rewarded for his aristocratic anesthesia by having his own leg broken, so that he can suffer like the rest. If pain is pedagogical, as Burke thought it could be, then a broken leg will teach Markow to know better next time.

In Burke and Lewis, losing one's sense of the other as other--a loss that precipitated the larger breakdown of the social fabric--was related to the anesthetizing of one's own pain; if one could not feel one's own sentient principle, as Whytt described it, then one could not feel that other, more wonderful social sympathy. To the degree that one's body is the source of the moral order, the mind's relationship to it is homologous to its relationship with all others. In Don Juan, the kind of social anesthetizing we just saw in General Markow suggests the possibility of losing one's sense of one's own self, by having it swallowed up in the sublime of widespread destruction. Byron directly takes on this tendency by reclaiming in the body the isolating agency of pain that is otherwise lost in the overwhelming carnage. As the scene at Ismail begins to resemble scarlett O'Hara's hospital grounds at Para, the focus shifts to a particular--and particularly gruesome--scene in which a dying Moslem bites the Achilles tendon of a Russian soldier who is walking over him:

In vain [the Russian] kicked and swore and writhed and bled And howled for help as wolves do for a meal. The teeth still kept their gratifying hold, 
As do the subtle snakes described of old. (VIII 83 ,

Such power have these dentures that even when the Moslem's head is cut off, they do not readily release their grip. Clearly, the soldier's foot here is Byron's cwn; both author and character have come face to face with their own Achilles's heel, the site of their human frailty. But by invoking the individual experience of pain here, Byron returns the aesthetic focus to a comprehensible perspective, and rescues the soldier's physical sentience from its disappearance into the black hole of the grotesque. (The Moslem's grotesquerie we are presumably not to notice.) Byron isolates one body in the context of thousands and renders its pain lucid, immediate, poignant. As in Byron's sexuality, the body nere employs sentience to reclaim its autonomy from an undifferentiated mass that constantly threatens to obliterate the immediacy of its experience. In fact, as Elaine Scarry argues, pain becomes an aesthetic proclamation of one's existence; it employs its tyranny toward a kind of ontological valiation. We see this same proclamation in an earlier scene of Don Juan when Juan, as the only survivor of the rowboat disaster, washes up on the shore of a beach "[w]ith just enough of life to feel its pain/ And deem that it was saved . ." (II 108,7-8). Pain becomes a beneficent confirmation here, rather than a tyrannical oppression.37 As Byron wrote in a letter to Annabella Milbanke, his future wife, on 6 september 1813, "The great object of life is sensation--to feel trat we 
exist--even though in pain. . . "30 In pain, we exist not in spite of our sentience but because of it.

In Matthew Lewis's antijacobin Gothicism, pain is employed to construct an aristocratic utopia of sorts. In Byron's more republican sympathies, this utopia is recast: pain is an individual experience that to some degree reconciles us with a much larger community by reducing the hero to the level of the common. As the same Russian officer writhes in pain, the regimental surgeon is called to relieve him. But to no avail: "The Russian officer for life was lamed,/... [w]hich left him 'midst the invalid and maimed" (VIII 85,2-4). Similarly, two soldiers who have had their hips and shoulders split open by Juan's sword rush off "to seek/ If there might be chirurgeons who could solder/ The wounds..." (VIII 94,2-4). But Byron refuses to cure or anesthetize the pain: "the fact's a fact," he tells us (VIII 86,1 ), and truth in poetry requires that pain be presented, not numbed. Yet unlike Lewis, Byron's sentience democratizes him at the same time that it individuates him; the soldier's pain makes him one of the countless many, despite the particularity of the close-up. If, with Descartes, we share the body in common, then we all share the potential for pain, a potential that reenfranchises us as part of the republic (or, reduces us to the common herd, depending on your point of view). Thus, through pain, Byron achieves at least two reconciliations: first, pain provides him a framework within which to situate the individual whose autonomy risks being swallowed up at the same time that it 
incorporates itself into the larger community (and this reconciliation is essential. for an individualist turned Republican, and for the Romantic in general); second, it at least partially reconciles Byron to his okn painful body. The "fact" of his lameness is a "fact," useless to bemoan and impossible to anesthetize. And more importantly, this pain affirms the life of sensation, which Byron refuses his fictional physicians the privilege of numbing. Through Canto VIII, Byron can to some degree validate both his politics and his ontology by examining the vicissitudes of pain, and thereby transform his tyrannically painful body into an agent of freedom.

Byron's exploration of the ontological aesthetics of pain presents him, naturally, with a problem in literary aesthetics: how does one render in literature the horrors of war and the immediacy of pain? In essence, Byron's problem is Lewis's: how does one represent physical horror without it becoming anesthetizing and numbing? He puts the case:

It is an awful topic, but 'tis not My cue for any time to be terrific.

For checkered as is seen our human lot

With good and bad and worse, alike prolific of melancholy merriment; to quote

Too much of one sort would be soporific. Without, or with, offence to friends or foes, I sketch your world exactly as it goes. (VIII 89) 
To avoid the tendency of the "terrific" to become "soporific"-the aesthetic to become anesthetic--Byron reports the facts, but with a reserve that maintains one's interest while reading: "one good action in the midst of crimes/ Is 'quite refreshing'. . ." (VIII $90,1-2)$. But even as he restrains himself from indulging a Gothic sensibility, he charges such restraint with being the "pretty milk-and-water ways" of a readership far too delicate, who prefer rhymes bedewed with ambrosia rather than with the blaze of epic battle (VIII 90). The English public, he suggests, prefer a hygienic literature, always already anesthetized against the fact of pain. Thus, Byron fashions a style that cuts both ways: knowing that mass pain and destruction can do for us what the regimental surgeon could not do, that is, anesthetize, Byron edits, focusses, and particularizes the moment of pain. Yet, unwilling to compromise his commitment to the materiality of war, he edits in order to keep those horrors fresh and immediate. Like Burke, Byron avoids the anodyne draught of oblivion that comes from excess, but he does so in order to keep our sensibilities alive to the ambiguities of revolution and to the body in pain, rather than to advocate the cant of a clear party line.39 Burke asks us to feel pain so that we can control it; Byron asks us to feel pain so that we can critique the political structures that inflict it.

In his early life, Byron attempts to escape pain by reading fiction; he supplants one form of the aesthetic (ontological sentience) with another (art). But this move is not a simple 
deflection or repression. Rather, the fiction he writes in his last days emphasizes his concern for physical pain, pain without mitigation. For Watkins, this is a move from ideology to materiality, away from whiggish cant to the historical conditions that constitute meaning.10 For Jerome McGann, the later cantos of Don Juan (particularly those on England) are "the drama of romantic poetry where one becomes what one beholds, where education must be suffered through, where every poet is an Apollyon who must be pierced with his own weapon."41 To be pierced with one's own weapons is to become aware that one is trapped by violence, to know that pain is not only inescapable, but compulsory. But with this compu?sory pain comes the promise of revolution. Improvements to the quality of life, says Byron, require "weapons such as men/ snatch when despair makes human hearts less pliant./. . . I would fain say 'fie on't',/ If I had not perceived that revolution/ Alone can save the earth from hell's pollution" (VIII 51,3-8). Byron honoured his commitment to revolution by assisting the Italian Carbonari and by volunteering for the Greek struggle. And this same liberation-and the immediacy of pain--await England:

Think how the joys of reading a Gazette Are purchased by ail agonies and crimes. or if these do not move you, don't forget such doom may be your own in after times. (VIII $125,1-4)$ 
England assumes that it is free from revolutionary violence. Indeed, Burke has won. But the inoculation which Burke has given to England is not a cure but an anaesthetic, exactiy like the kind Burke feared in France, which numbs the body politic to its real tyrannies--the tyrannies of a Castlereagh, a Wellesley, a George III. And it is a temporary aneschetic precisely because the revolution, for Byron, is inevitable; the sentience of the body politic cannot be anesthetized. This re-aestheticizing is the role of the poet. Through him, none will forget the "shrieks and groans" that the Russian sovereignty inflicted on the people of Ismail (VIII 135,2): "For I will teach, if possible, the stones/ To rise against earth's tyrants" (VIII 135,4-5). No longer does the aesthetic risk becoming anesthetic; rather, as a political poetry, it obliterates the numbness of political conservatism and re-enlivens, or re-aestheticizas, the body politic. 
Notes

1.Lord Byron, Dor Juan (Markham, Ont.: Penguin, 1987), X,42,1-4.

2.This cooperation really began much earlier, with the establishment of the Royal College of Physicians in England in 1522. But advancements were slow until the eighteenth-century, when legislation and societies begrn to proliferate. See Wyndham E.B. Lloyd, A Hundred Years of Medicine (New York: Humanities Press, 1968), p. 53; and Lester S. King, The Medical World of the Eighteenth Century. (Huntington, N.Y.: Robert E. Krieger, 1971), p. 2 .

3. Actually, the construction of the body image in France did not proceed regardless of class. As outram points out, the revolutionary imaging of the body was a particularly middle-class phenomenon which remained at a loss to understand the peasant body from which it remained alienated. Hence, the peasant body was usually figured as fat, poorly defined, and disgusting, th reby leaving class stratification still intact (p. 60).

4. As Outram writes, Bordeu sought in his attack on Descartes "a much more holistic view of the organism as a self-propelling, self-regulating entity, whose 'vital force' came from within $j$ ts interior, instead of as a result of receptors to stimuli applied from the outside" (p. 54). The result of this search was the all-important elevation of the concept of "sensitivity":

Without attributing all this [ie. reactions to stimuli] 
to any metaphysical entity, Bordeu saw the organism as possessing something one may call a force, capable of executing functions that no blind mechanical motor could. This was the force to which Bordeu gave the name "sensitivity," a property which he considered to be diffused by the nerves, not only to some parts of the organism, but throughout the whole of it. (p. 55)

5. One particular illustration of this is the surgeon William Chiselden (1688-1752), who not only made sure that his knives were perfectly sharp before he performed surgery, but was actually nauseated the night before the operation over the pain that he was about to inflict. For this anecdote, see Daniel de Moulin, "A Historical-Phenomenological Study of Bodily Pain in Western Man," Bulletin of the History of Medicine 48 (1974), pp. 545-546.

6.Victor Robinson, Victory Over Pain: A History of Anesthesia (New York: Henry Schurman, 1946), p. 55. Priestley did not discover anesthesia, merely a safer form. The first non-narcotic anesthesia to be introduced to England was in the form of a nerva compression machine, which was invented by James Moore in 1784 . This method was further developed, al though not respected, by Benjamin Bell, whose system of surqery becarie a standard eighteenth-century medical text. See Bernard Seeman, Man Against Pain: 3000 Years of Effort to Understand and Relieve Human Suffering (New York: Chilton, 1962) p. 103. 
7.Robinson, Victory over Paing, p. 40. Narcotics were the chief form of physical. analgesic to be associated witi quackery and to be dismissed. The popular contemporary form of psychological analgesia came in the work of Friederich Anton Mesmer (of our current "mesmerism") whose complex system of anesthetizing hypnosis and magnetic treatment of illness achieved immediate but fleeting popularity (Moulin, "Historical," p. 543).

8. René Fülop-Miller, Triumph Over Pain (New York: Bobbs-Merrill, 1938), p. 72 .

9.David George Hale, The Body Politic: A Political Metaphor in Renaissance English Literature (The Hague: Mouton, 1971), pp. 78.

10.For J.G.A. Pocock, the seat of this concord is a respect for church estates ("The Political Economy of Burke's Analysis of the French Revolution," Historical Journal 25 [1982], p. 334; for James T.Boulton, it is centered in the concept of Natural order (The Language of Politics in the Age of Wilkes and Burke, [Toronto: University of Toronto Press, 1963], p. 110; and for Gary Kelly, it is a respect for gentry ("Revolution, Crime, and Madness: Edmund Burke and the Defense of the Gentry," EighteenthCentury Life 9 [1984], pp. 16-32). While these fixations appear somewhat disparate in the separate critics, they contribute to defining Burke's overall love of the idea of the traditional. For Burke, as for Pope, whatever is, is right. 
11 . Lanquage of Politics, p. 117.

12. The information Burke got in these early days was specious to say the list. According to William Palmer, Burke got most of his information from the British newspapers, and thus were subject to their biases and interpretations ("Edmund Burke and the French Revolution: Notes on the Genesis of the Reflections, "Colby Library Quarterly. 20 [1984], pp. 181-190). The limitations which the media imposed upon Burke's political position seem not that much different from our own, as we become conscious of having witnessed events in Vietnam or the Middle East solely through journalistic interpretation.

13. Jacques Derrida, Disseminations, trans. Barbara Johnson (Chicago: University of Chicago Press, 1981).

14. Quoted in George Watson, "Burke's Conservative Revolution," Critical Quarterly $26(1984)$, p. 4 .

15. Matthew Gregory Lewis, The Monk (New York: Oxford University Press, 1987$),$ P. 326 .

16. Representations of Revolution, p. 223. This ambivalence is replayed in the mob's stoning of the Prioress near the end of the novel. As an evil tyrant, she deserves what she gets, but the image of a mob out of control is terrifying, for they become completely indiscriminate in their slaughter. 
17.Daniel P. Watkins, "Social Hierarchy in Matthew Lewis's The Monk," studies in the Novel 18 (1986), pp. 115-124.

18. Matthew Gregory Lewis, The Life and Correspondence of M.G. Lewis Vol. I, ed. Margaret Baron-Wilson (London: Henry Colburn, 1839), P. 292 .

19. Ibid., p. 371 .

20.As Howard Anderson notes in his Introduction tc he Monk, Lewis always enjoyed moving in high society, and amusing the assemble' company with his fascinating anecdotes. However, as Byron makes clear, Lewis's anecdotes were more amusing to himself than to anyone else, and he had the reputation of being a notorious bore. (See Byron's Letters IX, p. 18.)

21 . Letters III, p. 234.

22. Leslie Marchand, Byron: A Biography, Vol I (New York: Alfred A. Knopf Ltd., 1957), p. 56.

23. Quoted in Leslie Marchand, Introduction to Lord Byron: Selected Letters and Journals (Suffolk: Picador Eooks, 1982), p. 11 .

24. Biography, p. 56 . 25. Ibid., p. 54 . 26. Ibid., p. 1052 . 
27. "Manfred," in Poetical Works, I, $i, 7$.

28. Letters II, p. 89.

29 . Letters VI, p. 92 .

30. "Romanticism and Its Ideologies," p. 586.

31."Byron and the Poetics of Revolution," p. 96, and "violence, Class Consciousness, and Ideology in Byron's History Plays," ELH: English Literary History. 48 (1981), pp. 799-816.

32. Morse Peckhan, Beyond the Tragic Vision: The Quest for Identity in the Nineteenth Century (New York: G. Braziller, 1970), p. 101 .

33. Romantic Ventriloquists, p. 269.

34.Jürgen Klein, "Byron's Idea of Democracy: An Investigation into the Relationship Between Literature and Politics," in Byron:

Poetry and Politics; Seventh International Byron Symposium.

Salzburg, 1980, Ed. Erwin A. Sturzl and James Hogg (Salzburg: Institut fur Anglistik und Amerikanistik, 1981), pp. 58-58.

35. I am not suggesting a conscious re-writing of Burke here. There is no evidence to suggest that Byron actually read the Reflections, although it is inconceivable that he wouldn't have. Steffan, Steffan and Pratt suggest that Byron no doubt had enormous respect for Burke, and "was probably attracted to him by Burke's efforts on behalf of India and American colonies, his 
passionate lack of restraint, his life-lonr support of the traditional order and of free parliamentary processes, and especially by his formal eloquence" (p. 613). I would add to this a respect for Burke's love of gradualism in political reform: like Burke, Byron respected Americans because they "acquired their freedom by firmness without excess" (Letters p. 265). While Byron's thoughts on the efficacy of revolutionary excess changed as he grew older, he did advocate a peaceful change whenever it was possible.

36. Frederick Garber, "Self, Society, Value, and the Romantic Hero," Comparative Literature 19 (1967), p. 321.

37. This is not the only instance in Don Juan where bodily infirmity can act as a blessing. When Juan and a group of others are set adrift in the famous rowbot scene which comprises much of Canto II, the passengers are forced into acts of cannibalism as a means of staying alive. After they have eaten Juan's spaniel and his tutor Pedrillo, they turn to the first mate, who is the fattest--and therefore healthiest, in a pre-aerobics culture--of the survivors. The mate is saved from Pedrillo's fate, however, by pointing out that

He had been rather indisposed of late, And that which chiefly proved his saving clause Was a small present made to him at Cadiz,

By general subscription of the ladies. (II, 81,5-8) Normally, one does not wish to be stricken with venereal disease, 
but in this case illness is actually a protection, an assurance of life at the same time that it threatens it. In other words, contagion can be its own Erophylactic.

38. Letters III, p. 109 .

39. This double-edged style might of course be called satire. In satire, we are both aestheticized--in that we are made to feel the bitter sting of a crime, infidelity, or indiscretion--and anesthetized--in that we are forced to keep a critical distance from the immediacy of the scene. Byron ostensibly respects the delicacy of "ears polite"" (VIII 93,6 ) by refusing to report Juan's cursing, yet ridicules this delicacy by describing the physical slashing of the Russian bodies in the next stanza. In this graphic violence, we are invited both to feel the immediacy of the pain, and yet to remain aloof from it, aware that this is really all a "joke". Such a definition of satire, however, is beyond the scope of this study. 40."Violence, Class Consciousness, and Ideology," p. 91. 41. "Romanticism and Its Ideologies," p. 597. 
Conclusion

Burke knew that an empowered body--in the form of an empowered body politic--could rage out of control, and he feared this power. Wordsworth and Coleridge feared it too; Lewis was ambivalent about it; Byron hoped for it. The body in these writers' texts is highly charged, in that it contains the possibilities of political strength, a strength which can result in the destruction of the old order. But this fearful, empowered body in the works I have discussed is also placed under attack: it is rent, dismembered, afflicted, diseased, or maimed. Its power is put in check by pain. In this pain, moreover, there is a further curtailment of the potential for social and political affiliation. I have tried to trace a dialectic of pain from the imaginative identification with pain (I know how you feel). through the usurpation of that pain (This hurts me more than it hurts you), to the isolation and paradoxical empowerment of the self through pain (I hurt, therefore I am). What I hope to have shown here is a variant reading of a tradition of Romantic criticism most clearly articulated by René Wellek, who saw in the late eighteenth century a move toward the breakdown of subjectobject relations. This tradition gets picked up in criticism of the Gothic by people like Eve Kosofsky Sedgwick, who describes the Gothic as the undermining of "the identification of center with self and [of] the programmatic symmetry of the insideoutside relation." I I am arguing that physical pain re-instates 
the subject-object gap. By its peculiarly individual nature, pain isolates and confines. In the fiction I have discussed, the destruction of the other's body results in the construction of one's self.

This complex dialectic of physical destruction and subjective construction depends upon maintaining the tension I earlier described as "aesthetic," a tension rooted in the body. To polarize the terrific and the soporific; to distinguish the aesthetic from the anesthetic; to keep too much feeling from becoming too little--this is the challenge that writers of Romantic fiction faced as they thought about their own and others' pain. What seems to be at stake here is a way of regulating fiction's appeal to corporeal stimulation in order to allow identification with the highly charged, hurting body, while at the same time keeping a necessary distance from that stimulation so that it does not become excessive and numbing.

This challenge is acutely felt by Mary Shelley who, perhaps more clearly than any other Romantic novelist, allegorizes the problems inherent in constructing a self. As shelley troubled herself over how to write the ghost story with which Byron had charged her in 1816, she knew she wanted a stu= $y$ lihat would appeal directly to the body, one "which would speak to the mysterious fears of our nature, and awaken thrilling horror--one to make the reader dread to look round, to curdle the blood, and quicken the beatings of the heart."2 Yet, as she writes in the Preface to Frankenstein, or The Modern Prometheus, "my chief 
concern. . has been limited to avoiding the enervating effects of the novels of the present day" (p. 25). Out of this delicate balancing act shelley produces her "hideous progeny"--her text and her monster. And like the monster, the text is both an expression of Romantic virtue and a proclamation of Gothic physical affliction.

As a study in consciousness, Frankenstein is all too Romantic, in that it documents the desire to have someone know how you feel. The novel is, among other things, a search for friendship: Captain Walton, the framing narrator, introduces the problem by complaining to his sister:

I have no friend, Margaret: when I am glowing with the enthusiasm of success, there will be none to participate my joy; . . . I desire the company of a man who could sympathize with me; whose eyes would reply to mine. You may deem me romantic, my dear sister, but I bitterly feel the want of a friend. (p. 28)

(Margaret, the sympathetic ear to this bemoaning of the lack of a sympathetic ear, presumably does not take this personally.) Victor shares Walton's "thirst for a more intimate sympathy than had ever fallen to my lot," for, without this sympathy, says victor, "we are unfashioned creatures, but half made up . . ." (p. 36). And half made up indeed is Victor's monster, who has no being to resemble him (p. 107), to share his thoughts, to complete him (p. 114). But when Victor gets what the novel so clearly cries out for, he doesn't want it: having someone else 
know how you feel is not dissimilar to having them possess and haunt you. The monster always knows where Victor is, with whom he is conversing, and whom he is loving. Victor reflects:

I considered the being whom I had cast among mankind, and endowed with the will and power to effect purposes of horror. . nearly in the light of my own vampire, my own spirit let loose from the grave, and forced to destroy all that was dear to me. (p. 73)

The desire for a sympathetic other is exaggerated to the point where the breakdown in subject-object relations becomes a hideous and terrifying experience of possession. The Gothic is not a poor cousin to Romanticism so much as it is its progeny, the (un)natural end of a desire for sympathetic intercommunication.

But Frankenstein not only embodies the fear of possession; it also possesses the fear of embodiment. What is fearful about the monster is not only that he knows us too well, and that he is inside of us, but also that as a physical, material being, he defies all control. Mary Shelley's novel is, at a very basic level, a novel about a body: a body that is made, a body that is theoretically perfect, and a body that goes tremendously wrong. Victor, like Schwarzenegger, has set out to make the perfect body: "I resolved. . . to make the being of a gigantic stature" (p. 55); "His limbs were in proportion, and I had selected his features as beautiful. . ; his hair was of a lustrous black, and flowing; his teeth of a pearly whiteness" (p. 58). Indeed, the monster later reminds victor that "thou hast made me more 
powerful than thyself; my height is superior to thine; my joints more supple" (p. 90). The monster is an attempt to fashion a body that would be both strong and submissive, both magnificent and malleable. In a way, the monster is an allegorical representation of the body as C.B. Macpherson described it (see my first chapter). it is the body that culture works on, fashions, and makes into a certain image. But, as Macpherson reminds us in his analysis of Locke, we fashion this body in order to alienate it by selling it on the open market. The history of bourgeois economy since at least the seventeenth century is the story of bodies made powerful and alienated. Frantenstein is that story. In shelley's novel, the perfect body is the hideous body; it is a body out of control which wreaks: destruction and death. Victor's monster is too much of a good thing.

The fear of the body that the monster represents is paralleled in Victor's abuse of his own body. As he recounts his making, he describes in almost inverse proportion the decay of his own physical strengths: "My cheek had grown pale with study, and my person had become emaciated with confinement" (p. 55); "my eye-balls were starting from their scckets in attending to the details of my employment" (p. 56); wracked by "incipient disease," "I appeared rather like one doomed by slavery to toil in the mines. . . Every night I was oppressed by a slow fever, and I became nervous to a most painful degree" (p. 57); "I was a shattered wreck,--the shadow of a human being. My strength 
was gone. I was a mere skeleton; and fever night and day preyed upon my wasted frame" (p. 154). P.s Victor makes his monster, he becomes unmade. This decay of physical strength is of course repeated in the decay in emotional strength: as victor builds a self and releases that self to the world, his own sense of self falls apart. He retreats from his community of friends, his family, and his fiance; he entraps himself in a solitude from which there seems no escape. Like the monster, Victor becomes a "restless spectre, separated from all it loved" (p. 143). In the Gothic novels I've discussed, the destruction of the other's body results in the construction of the self. In Frankenstein, the construction of the body results in the destruction of the self.

In Frankenstein, and in the Gothic novel generally, the fear of community is a fear of the body: communal sympathy can too easily become threatening victimization, haunting, possession--in short, the usurpation of self. The monster's ultimate demand for a mate, for someone with whom to sympathize, is for victor the pinnacle of this threatening physicality:

I was now about to form another being, of whose dispositions I was alike ignorant; she might become ten thousand times more malignant than her mate, and delight, for its own sake, in murder and wretchedness. (p. 140)

And not only might they delight in murder and physical violence, they might also want to procreate, "and a race of devils would be propagated upon the earth, who might make the very existence of 
the species of man a condition precarious and full of terror" ( $p$. 140). With this fear of monstrous physicality (not untinged by misogyny), victor, like Fleetwood, "tore to pieces the thing on which I was engaged" (p. 141). Yet, this destruction of physicality does not regulate the power represented by physicality itself. The monster, as a physical strength, continually threatens to exert itself. Its Gothic body, both highly charged and highly repressed, threatens to return from its repressions, to overpower that mind which gave it birth. In this novel, victor's soul is as much a prisoner of the monster's body as the monster's body is a prisoner of victor's soul. At a moment near the end of that great mind-body dialogue that is the center of the novel, the monster tells Victor, "You are my creator, but I am your master;--obey!" (p. 142). This is the fear of the body in Romantic fiction, and perhaps in Western culture at least since Descartes. We create an empowered body which demands that we obey it. And sometimes, we fear, we might. 
Notes

1. Coherence, p. 13. See also Maggie Kilgour, From Communion to Cannibalism: An Anatomy of Metaphors of Incorporation (Princeton: Princeton University Press, 1990), p. 168; and Terry Castle, "The Spectralization of the other," in Felicity Nussbaum and Laura Brown (eds), The New Eighteenth Century: Theory, Politics. English Literature (New York: Methuen, 1987), p. 237 .

2.Mary Shelley, Introduction to Frankenstein or The Modern Prometheus, ed. Johanna M. Smith (Boston: St. Martin's Press, $2992)$, p. 22 . 
Bibliography

Abrams, M.H. Natural Supernaturalism: Tradition and Revolution in Romantic Literature. New York: W.W. Norton and Co., 1971 .

Addison, Joseph, Richard Steele and others. The spectator. Ed. Gregory Smith. New York: Everyman's Library, 1967.

Albrecht, W.P. "Tragedy and Wordsworth's Sublime." The Wordsworth Circle 8 (1977): 83-94.

Allott, Miriam. Essays on Shel ley. Totowa: Barnes and Noble, 1982 .

Austen, Jane. The Complete Novel s of Random House, n.d.

Averill, James $H$. Whordsworth and the Poetry. of Human Suffering. Ithaca: Cornell University Press, 1980.

Barish, Jonas. The Antitheathrical Prejudice. Los Angeles: University of California Press, 1981 .

Barker, Francis et al. 1789: Reading, Writing, Revolution-: Proceedings of the Essex Conference on the sociology of Litterature, July 1981 . Essex: University of Esstx Press, 1982 .

Beccaria, Cesare. On Crimes and Punishments (Dei Delitti e delle Pene). Trans. Henry Paolucci. New York: BobbsMerrill Publishers, 1963.

Beer, John. Wordsworth. and the Human Heart. New York: Col umbia University Press, 1978 . 
Bender, John. Imagining the Penitentiary: Fiction and the Architecture of Mind in Eighteenth-Century England. Chicago: University of Chicago Press, 1987.

Benedict, Barbara M. "Pictures of Conformity: Sentiment and Structure in Ann Radcliffe's style." Philological. Quarterly 68 (1989): 363-377.

Benjamin, Walter. Il luminations. Trans. Hannah Ärencit. New York: Schocken Books, 1969.

Blackstone, Sir William. Commentaries on the Laws of Eng?and. Vol. IV. New York: Garland, 1978.

Bostetter, Edward. The Romantic Ventri $\underline{i}$ loguists: Wordsworth, Coleridge, Keats, Shel ley, Byron. Seattle: University of Washington Press, 1963.

Boulton, James T. The Language of Politics in the Age of wilkes and Burke. Toronto: University of Toronto Press, 1963.

Brissenden, R.F. Virtue in Distress:-studies in the Novel of Sentiment from Richardson to Sade. New York: Barnes and Noble, 1974.

Bruns, Gerald. "Wordsworth at the Limits of Romantic Hermeneutics." The Centennial Review 33 (1989): 402403.

Bryson, Norman. Tradition and Desire from David to Delacroix. New York: Cambridge University Press, 1987.

Burke, Edmund. A Phil osophical Enquiry into the origin of our I deas of the subl ime and Beautiful. Ed. James T. Boulton. London: University of Notre Dame Press, 1958. 
- Reflections on the Revolution in France. Ed.

Conor Cruise O'Brien. Markham, Ont.: Penguin, 1986.

Butwin, Joseph. "The French Revolution as Theatrum Mundi."

Research studies 43 (1975): 141-152.

Byron, George Gordon, Lord. Byron's Letters and Journals. Ed.

Leslie Marchand. New York: Alfred A. Knopf, 1957. - Byron: Poetical Works. Ed. Frederick

Page and John Jump. New York: Oxford University Press, 1987.

- Lord Byron: Sel ected Letters and

Journals. Suffolk: Picador Books, 1982 .

Carter, Angela. The Sadeian Woman and the Ideology.of

Pornography. New York: Pantheon Books, 1978 .

Cave, Richard Allen (ed). The Romantic Theatre: An Internationol

Symposium. Totawa: Barnes and Noble, 1986.

Coleridge, Samuel Ta:lor. Biographia Literaria, or Biographical

Sketches of My Literary Life and Opinions. London:

Everyman's Library, 1987.

- The Col lected Works of Samuel Tay lor

Coleridge. Vol. 4. Ed. Barbara Rooke. Princeton:

Princeton University Press, 1969.

- The Complete Poetical Works of Samuel

Tay lor Coler iㅕㅁㅡ. Vol. II. Ed. Ernest Hartley

Coleridge. Oxford: Clarendon Press, 1957.

- Letters of Samuel Tay lor Col eridge.

London: William Heineman, 1895. 
Chandler, James $r$. Wordsworth's Second Nature: A study of Poetry and Politics. Chicago: University of Chicago Press, 1984.

Christensen, Jerome. "Marino Faliero and the Fault of Byron's Satire." Studies in Romanticism 24 (1985): 313-333. Cox, stephen D. "The Stranger Within Thee": Concepts of the Self in Late Eighteenth-Century Literature. Pittsburgh: University of Pittsburgh Press, 1980.

Curran, stuart. Shelley's."Cenci": Scorpions Ringed With Fire. Princeton: Princeton University Press, 1970. Day, William Patrick. In the Circles of Fear and Desire: A study of Gothic Fantasy. Chicago: University of Chicago Press, 1985.

de Almeida, Hermione. Romantic Medicine and John Keats. New York: Oxford University Press, 1991.

de Moulin, Daniel. "A Historical-Phenomenological study of Bodily Pain in Western Man." Bull letin of the History of Medicine $48(1974): 540-570$.

Derrida, Jacques. Disseminatinn. Trans. Barbara Johnson. Chicago: University of Chicago Press, 1981. de Sade, Donatien Alphonse. The Complete Justine, Philosophy in the Bedroom, and other Writings. Trans. Richard Seaver and Austryn Wainhouse. New York: Grove Press, 1965. . De Sade's_Selected Writings. Trans. Leonard Saint-Yves. London: Peter Owen Limited, 1953. 
Doughty, Oswaid. Perturbed Spirit: The Life and Personality of Samuel Tayl or Coleridge. Toronto: Associated University Presses, 1981 .

Durant, David. "Ann Radcliffe and the Conservative Gothic." SELL:

Studies in Engl ish Literature, 1500-1900 22 (1982): 519-530.

Eagleton, Terry. The Ideology of the Aesthetic. Oxford: Basil Blackwel1, 1991 .

Erdman, David. "Byron's Stage Fright: The History of His Ambition and Fear of writing for the stage." ELH 41 (1939): 219243.

Fawcett, Mary Laughlin. "Udolpho's Primal Mystery." SEL: Studies

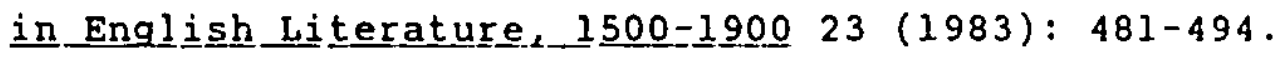
Ferry, David. The Limits of Mortality: An Essay on Wordsworth's Major Poetry. Middleton, CT.: Wesleyan University Press, 1959 .

Foucault, Michel. The Birth of the Clinic: An Archeology of Medical Perception. Trans. A.M. Sheridan Smith. New York: Vintage Books, 1975. - Discipline and Punish: The Birth of the prison.

Trans. Alan Sheridan. New York: Vintage Books, 1979. Föulop-Miller, Rene். Triumph Over Pain. New York: Bobbs-Merrill, 1938.

French, R.K. Robert Whytt, the Soul, and Medicine. London: St. Ann's Press, 1969. 
Freud, sigmund. The standard Edition of the Complete

Psychological Works of Sigmund Freud. Vol. 17. Trans. James Strachey. London: Hogarth Press, 1955.

Fried, Michael. Absorption and Theatricality: Painting and

Beholder in the Age of Diderot. Berkeley: University of California Press, 1980 .

Fuss, Diana. Essentially speaking: Feminism, Nature, and

Difference. New York: Routledge, 1989.

Garber, Frederick. The Autonomy of the Self from Richardson to

Huysmans. Princeton: Princeton University Press, 1982. . "Self, Society, Value, and the Romantic Hero."

Comparative Literature 19 (1967): 321-333.

Gervais, David. "Suffering in Wordsworth." The Cambridge

Quaaterly $16(1987): 1-14$.

Godwin, William. The Adventures of Caleb Williams, or Things as

They Are. San Francisco: Rinehart Press, 1960.

- Enquiry Concerning Political Justice and Its

Influence on Modern Morals and Happiness. Markham, Ont . :

Penguin, 1976.

- Fleetwood: or The New Man of Feeling. London:

Richard Bentley, 1853.

- Travels of st. Leon. London: Henry Colburn and

Richard Bentley, 1851.

Hale, David George. The Body Politic: A Political Metaphor in

Renaissance English Literature. The Hague: Mouton, 1971 . 
Hanson, Elizabeth. "Torture and Truth in Renaissance England." Representations 34 (1991): 53-84.

Hazlitt, william. Lectures on the English Poets, and spirit of the Age, or Contemporary Portraits. New York: Dutton Publishing, 1967.

Heller, Janet Ruth. "The Bias Against Spectacle in Tragedy: The History of an Idea." The Eighteenth Century 22 (1982): 239-255.

Henderson, Andrea. "A Tale Told to be Forgotten: Enlightenment, Revolution, and the Poet in 'Salisbury Plain'." Studies in Romanticism 30 (1991): $71-84$.

Hennelly, Mark M., Jr. "The Slow Torture of Delay': Reading The Italian." Studies in the Humanities 14 (1987): 1-14.

Holland, Patrick. "Wordsworth and the Sublime: Some Further Considerations." The Wordsworth Circle 5 (1974): 17-22.

Howells, Coral Ann. Love, Mystery, and Misery: Feeling in Gothic Eiction. London: Athlone Press, 1978 .

Hume, Robert D. "Gothic vs. Romantic: A Revaluation of the Gothic Novel." PMLA 84 (1969): 282-290.

Jacobus, Mary. "That Great Stage Where Senators Perform': Macbeth and the Politics of Romantic Theatre." studies In Romanticism 22 (1983): 353-387.

Jones, [Henry] John [Franklin]. The Eqotistical Sublime: A History of Wordsworth's Imagination. London: Chatto and Windus, 1954.

Keats, John. The Letters of John Reats. Ed. Maurice Buxton Forman. Toronto: Oxford University Press, 1935. 
Kilgour, Maggie. From Communion to Cannibalism: An Anatomy of Metaphors of Incorporation. Princeton: Princeton University Press, 1990.

King, Lester S. The Medical World of the Eighteenth Century.

Huntington, N.Y.: Robert E. Krieger, 1971.

Lacan, Jacques. Écrits: A Selection. Trans. Alan Sheridan. New

York: W.W. Norton and Co., 1977.

Lewis, Matthew Gregory. The Castle Spectre (1798). Intro.

Jonathan Wordsworth. New York: Woodstock Books, 1990. - The Monk: A Romance. Toronto: Oxford

University Press, 1988. - Romantic Tales. London: Longman, Hurst,

Rees, and Orme, 1808 .

Leyda, Seraphia D. "Wordsworth's Sonnets Upon the Punishment of Death." The Wordsworth Circle 14 (1983): 48-53.

Lloyd, Wyndham E.B. A Hundred Years of Medicine. New York:

Humanities Press, 1968.

Locke, John. An Essay Concerning Human Understanding. Ed. Peter Nidditch. Oxford: Clarendon Press, 1988. - Two Treatises of Government. Darmstadt: scientia Verlag Aarlen, 1963.

London, April. "Ann Radcliffe in Context: Marking the Boundaries of The Mysteries of Udolpho." Eighteenth-Century Life $10(1986): 35-47$. 
MacDonald, D.L. "Bathos and Repetition: The Uncanny in Radcliffe." Jounal of Narrative Technique 19 (1989): 197-204.

Macpherson, C.B. The Political Pheory of Possessive Individualism, Hobbes to Locke. Oxford: Oxford University Press, 1962.

Madonna, and Patrick Leonard. "Hanky Panky" from Madonna: I'm Breathless. Warner Brothers Music, Corp., 1990.

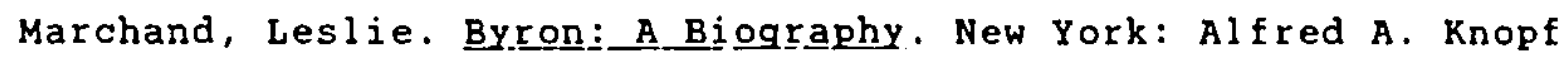
Ltd. , 1957.

Marshall, David. The Figure of Theatre: Shaftesbury, Defoe, Adam Smith, and George Eliot. New York: Columbia University Press, 1986. - The Surpising Effects of Sympathy: Marivaux. Diderot, Rousseau, and Mary Shel ley. Chicago: University of Chicago Press, 1988.

Mann, Ronald (ed). The History and Management of Pain from Early Principles to Present Practice. Park Ridge, New Jersey: Parthenon Books, 1988 .

McCracken, David. "Godwin's Literary Theory: The Alliance between Fiction and Political Philosophy." Philologogical Quarterly 49 (1970): 113-133. . "Godwin's Reading in Burke." English Language Notes $7(1970): 264-270$.

Moore, John David. "Coleridge and the 'modern Jacobinical Drama': Osorio, Remorse, and the Development of Coleridge's 
Critique of the Stage, 1797-1816." Bulletin of Research in the Humanities 85 (1982): 443-464.

Morris, David B. The Culture of Pain. Berkeley: University of California Press, 1991.

Mullan, John. Sentiment and Sociablity: The Lanquage of Feeling in the Eighteenth Century. Oxford: Clarendon Press, 1988 .

Myers, Mitzi. "Godwin's Memoirs of Wollstonecraft: The Shaping of Self and subject." studies in Romanticism 20 (1981): $299-316$.

" "Godwin's Changing Conception of Caleb Williams." Studies in English Literature 12 (1972): 591-628. Neal, Helen. The Politics of Pain. New York: McGraw-Hil1, 1978 . Nussbaum, Felicity and Laura Brown (eds). The New Eighteenth Century: Theory, Politics, English Literature. New York: Methuen, 1987.

Nuttal, A.D. A Common Sky: Philosophy and the Literary Imagination. Berkeley: University of California Press, 1974 .

Outram, Dorinda. The Body and the French Revolution: Sex, Class and Poi ítical Culture. New Haven: Yale University Press, 1989.

Owen, W.J.B. "The Sublime and Beautiful in The Prelude." The Wordsworth Circle 4 (1973): 67-86. 
Paine, Thomas. The Rights of Man, Being an Answer to Mr. Burke's Attack on the French Revolution. Markham, ont.: Penguin, 1984.

Palmer, William. "Edmund Burke and the French Revolution: Notes on the Genesis of the Reflections." Colby Library. Quarterly 20 (1984): 181-190.

Parry, L.A. The History of Torture in England. New Jersey: Patterson Smith, 1975.

Paulson, Ronald. Representations of Revolution (1789-1820).

New Haven: Yale University Press, 1983.

Pechkam, Morse. Beyond the Traqic Vision: The Quest for Identity in the Nineteenth Century. New York: G. Braziller, 1970.

Peters, Edward. Torture. New York: Basil Blackwell, 1985.

Poovey, Mary. "Ideology and The Mysteries of Udolopho." Criticism $21(1979): 307-330$.

Praz, Mario. The Romantic Agony. Trans. Angus Davidson. New York: Oxford University Press, 1970.

Punter, David. "1789: The Sex of Revolution." Criticism: A Quarterly for Literature and the Arts 24 (1972): $201-$ 217 .

Radcliffe, Ann. The Italian; of The Confessional of the Black Penitents. Toronto: Oxford University Press, 1981. The Romance of the Forest. New York: Oxford University Press, 1986. 
- The Mysteries of Udolpho. Toronto: Oxford

University Press, 1984.

Rather, L.J. Mind and Body in Enlightenment Medicine: A Study

Based on Jerome Gaub's "De regimine mentis". London:

พilliam Clowes, 1965.

Robespierre, Maximilien. Textes choisis. tome II. Ed. Jean

Poperen. Paris: Editions Sociales, 1965.

Robinson, Victor. Victory Over Pain: A History of Anesthesia .

New York: Henry Schurman, 1946.

Rousseau, G.S. (ed). The Lanquages of Psyche: Mind and Body in

Enlightenment Thought. Berkeley: University of

California Press, 1990.

Rousseau, Jean-Jacques. Basic Political Writings of Jean-Jacques

Rousseaul. Ed. Donald A. Cress. Indianapolis: Hackett

Press, 1988 .

- Letter to $M$. d'Alembert on the Theatre.

Trans. Alan Bloom. Ithaca: Cornell University Press, 1968 .

Scarry, Elaine. The Body in Pain: The Making and Unmaking of the

World. New York: Oxford University Press, 1985. (ed). Literature and the Body: Essays on

Populations and Fersons. Baltimore: Johns Hopkins

University Press, 1988.

Sedgwick, Eve Kosofsky. Between Men: English Literature and Male Homosocial. Desire. New York: Columbia University Press, 1985. 
- The Coherence of Gothic Conventions. New

York: Methuen, 1986.

" "Jane Austen and the Masturbating Girl."

Critical_Inquiry 19 (1991): 818-837.

Seeman, Bernarc, Man Against Pain: 3000 Years of Effort to

Understand and Relieve Human Suffering. New York:

Chiltol, 1962 .

Sewell, Elizabeth. "Coleridge on Revolution." Studies in

Romanticism 11 (1972): 342-359.

Sheats, Paul. The Making of Wordsworth's Poetry, 1785-1798.

Cambridge, MA.: Harvard University Press, 1973.

Shelley, Mary. Frankenstein, or The Modern Prometheus. Ed.

Johanna M. Smith. Boston: St. Martin's Press, 1992.

Shelley, Percy Bysshe. The Complete Works of Percy Bysshe

Shelley. Vol.X. Ed. Roger Ingpen. New York: Gordian Press, 1965 .

- Shelley's Poetry and Prose. Ed. Donald H.

Reiman and Sharon B. Powers. Toronto: W.W. Norton and Co., 1977.

. Zastrozzi and st. Irvyne. New York: Oxford

University Press, 1986.

Simms, Karl N. "Caleb Williams" Godwin: Things as They Are Written." Studies in Romanticism 26 (1987): 343-63. Smith, Adam. The Theory of Moral Sentiments. Ed. D.D. Raphael and A.L. Macfie. Oxford: Clarendon Press, 1976. 
Smith, Nelson C. "Sense, Sensibility, and Ann Radcliffe." Studies in English Literature 12 (1973): 557-570.

Smith, Olivia. The Politics of Language 1791-1819. New York:

Oxford University Press, 1986.

Smith, W. Lynn et al. Pain: Meaning and Management. New York: SP Medical and Scientific Books, 1980.

Spector, Jack J. Delacroix: The Death of Sardanapalus. New York: Viking Press, 1974 .

Spierenburg, Pietre. The Spectacle of Suffering: Executions and the Evolution of Repression from a Preindustrial. Metropolis to the European Experience. New York: Cambridge University Press, 1984.

Sternbach, Richard (ed). The Psychology of Pain. New York: Raven Books, 1986.

Sturzl, Erwin A, and James Hogg (eds). Byron: Poetry and Politics; Seventh International Byron Symposium, Salzburg,.2980. Salzburg: Institut für Anglistik und Amerikanistik, 1981.

Storch, Rudolph. "Metaphors of Private Guilt and Social Rebeliion in Godwin's Caleb Williams." English Literary History $34(1967): 188-207$.

Sultana, Donald (ed). New Approaches to Coleridge: Biographical and Critical Essays. Totawa: Barnes and Noble, 1981. Swann, Karen. "Suffering and Sensation in The Ruined Cottage." PMLA $106(1991): 85-95$. 
Taylor, Charles. Sources of the Self: The Making of the Modern

Identity. Cambridge, Mass.: Harvard University Press, 1989.

Tetreault, Ronald. The Poetry of Life: Shelley and Literary

Form. Toronto: University of Toronto Press, 1987.

Thompson, G. Richard (ed). The Gothic Imagination: Essays in Dark

Romanticism. Pullman: Washington state Press, 1974.

Todd, Janet. Sensibility: An Introduction. New York: Methuen, 1986.

Tracy, Ann B. The Gothic Novel 1790-1830: Plot Summaries and Index to Motifs. Lexington: University of Kentucky Press, 1981.

Tysdahl, B.J. Will 1 am Godwin as Novelist. London: Athlone, 1981 . Varma, Devendra. The Gothic Flame: being a history of the Gothic novel in England: its origins, efflorescence, disintegration, and residual influences. New York: Russell and Russell Ltd., 1966.

Wasserman, Earl. "The Pleasure of Tragedy." ELH 14 (1947): 283307 .

- Shelley: A Critical Reading. Baltimore: Johns Hopkins University Press, 1971.

Watkins, Daniel P. "Byron and the Poetics of Revolution." KeatsShel ley Journal 34 (1985): 95-130.

"In That New World': The Deep Historical

structure of Coleridge's osorio." Philological

Quarterly $69(1990): 495-515$. 
- "Social Hierarchy in Matthew Lewis's The Monk." Studies in the Novel 18 (1986): 115-124. . "Violence, Class Consciousness, and Ideology in Byron's History Plays." ELH 48 (1981): 799-816. watson, George. "Burke's Conservative Revolution." Critical Quarterly 26 (1984): 87-99.

Wehrs, Donald R. "Rhetoric, History, Rebellion: Caleb Williams and the Subversion of Eighteenth-Century Fiction." SEL: Studies_in_English Literature_1500-1900 28 (1988): 497-511.

Wellek, René. "The Concept of 'Romanticism' in Literary History." Comparative Literature 1 (1949): 147-172. Welsford, Enid. Salisbury Plain: A study in the Development of Wordsworth's Mind and Art. Oxford: Basil Blackwell, 1966.

Whitman, Robert F. "Beatrice's 'Pernicious Mistake' in The Cenci." PMLA 74 (1959): 249-253.

Whytt, Robert. The Works of Robert Whytt. Edinburgh: Balfour, Auld, and Smellie, 1768 .

Williams, John. Wordsworth: Romantic Poetry and Revolutionary

Politics. New York: Manchester University Press, 1989. Woodring, Carl (ed). "Coleridge: The Politics of the Imagination." Studies in Romanticism 21 (1982): 445474.

- Politics in English Romantic Poetry. Cambridge, Mass.: Harvard University Press, 1970. 
- Politics in the Poetry of Coleridge. Madison:

University of Wisconsin Press, 1961.

Wordsworth, William. The Fourteen-Book Prelude. Ed. W.J.B. Owen.

Ithaca: Cornell University Press, 1985.

and Dorothy Wordsworth. The Letters of

William and Dorothy Wordsworth, Vol. I. The Early

Years, 1787-1805. Ed. Ernest de Selincourt. Oxford:

Clarendon Press, 1967.

- The Oxford Authors: William Wordsworth. Ed.

Stephen Gill. New York: Oxford University Press, 1989.

- The Poetical Works of Will iam Wordsworth.

Vol. 1. Ed. E. de Selincourt. Oxford: Clarendon

Press, 1944 .

- The Salisbury plain poems of filliam

Wordsworth. Ed. Stephen Gill. Ithaca: Cornell

University Press, 1975. 